Ana Paula Santos Delfino

Modelos Puros versus Híbridos: Uma análise de performance utilizando séries de vazões brasileiras

Dissertação de Mestrado

Dissertação apresentado como requisito parcial para obtenção do grau de Mestre pelo Programa de PósGraduação em Engenharia de Produção do Departamento de Engenharia Industrial da PUC-Rio.

Orientador: Prof. Fernando Luiz Cyrino Oliveira. 


$$
\text { Pontifícia } U_{\text {Niversidade }} \text { Católica }_{\text {do Rio de Janeiro }}
$$

Ana Paula Santos Delfino

\section{Modelos Puros versus Híbridos: Uma análise de performance utilizando séries de vazões brasileiras}

Dissertação apresentada como requisito parcial para obtenção do grau de Mestre pelo Programa de Pós-Graduação em Engenharia de Produção da PUC-Rio. Aprovada pela Comissão Examinadora abaixo assinada.

Prof. Fernando Luiz Cyrino Oliveira

Orientador

Departamento de Engenharia Industrial - PUC-Rio

Prof. Reinaldo Castro Souza

Departamento de Engenharia Industrial - PUC-Rio

Prof. Guilherme Armando de Almeida Pereira

Fundação Getúlio Vargas - FGV

Prof. Soraida Aguilar Vargas

Departamento de Engenharia Elétrica - PUC-Rio

Prof. Márcio da Silveira Carvalho

Coordenador Setorial do Centro

Técnico Científico - PUC-Rio

Rio de Janeiro, 23 de agosto de 2018 
Todos os direitos reservados. É proibida a reprodução total ou parcial do trabalho sem autorização do autor, do orientador e da universidade.

Ana Paula Santos Delfino

Graduou-se em Ciências Econômicas pela Universidade Federal do Rio de Janeiro (UFRJ) em 2016. Aluna de mestrado da PUC-Rio desde agosto de 2016.

Ficha Catalográfica

Delfino, Ana Paula Santos

Modelos puros versus híbridos: uma análise de performance utilizando séries de vazões brasileiras / Ana Paula Santos Delfino ; orientador: Fernando Luiz Cyrino Oliveira. -2018.

77 f. : il. color. ; $30 \mathrm{~cm}$

Dissertação (mestrado)- Pontifícia Universidade Católica do Rio de Janeiro, Departamento de Engenharia Industrial, 2018.

Inclui bibliografia

1. Engenharia Industrial - Teses. 2. Modelos híbridos. 3. Vazões. 4. Forecast. 5. Redes neurais artificiais. 6. ARIMA. I. Oliveira, Fernando Luiz Cyrino. II. Pontifícia Universidade Católica do Rio de Janeiro. Departamento de Engenharia Industrial. III. Título. 
Esta dissertação é dedicada à minha mãe. 


\section{Agradecimentos}

À minha mãe, Maria, agradeço por todo apoio em todos os momentos que precisei, educação, carinho, amor e confiança. Sem ela nada disso teria sido possível.

À sociedade brasileira por me conferir recursos para viabilizar a minha pesquisa.

Ao meu irmão, Thiago, pelo apoio incondicional.

As minhas amigas, Sandra e Tatiana, por todo apoio quando escolhi fazer o mestrado e por sempre acreditar que eu iria conseguir. Obrigada aos meus amigos e futuros mestres, Fatima e Victor, por terem me incentivado e dito que o mestrado era uma boa ideia.

À Hildete, pela amizade e apoio.

Aos meus colegas e amigos da PUC-Rio, obrigado por dividirem as dúvidas, experiências e por tornar toda essa trajetória um pouco mais fácil. Agradeço em especial Luiza, Kamila, Leonardo, Diego, Lucas, Pierry, Júlia, Vinícius, D’avila, Ludmilla e Fabiola, pessoas maravilhosas, que tive o privilégio de conhecer.

Ao Cezar, pela paciência, incentivo e por estar sempre ao meu lado nos momentos mais difíceis. Obrigado por tudo.

Ao Fernando Cyrino, por ter me guiado no processo de entrada no mestrado da PUC-Rio, acreditado no meu potencial, todo suporte, correções e oportunidade de desenvolvimento.

Aos professores do DEI/PUC-Rio por todo conhecimento compartilhado e pelas oportunidades de aprendizado.

A PUC-Rio, pelos auxílios concedidos e pelo excelente ambiente, materiais e professores disponíveis, sem os quais este trabalho não teria sido possível.

A todos aqueles que, de alguma forma, contribuíram para este trabalho, meu muito obrigado.

O presente trabalho foi realizado com apoio da Coordenação de Aperfeiçoamento de Pessoal de Nível Superior - Brasil (CAPES) - Código de Financiamento 001 


\section{Resumo}

Delfino, Ana Paula Santos; Oliveira, Fernando Luiz Cyrino (Orientador). Modelos Puros versus Híbridos: Uma análise de performance utilizando séries de vazões brasileiras. Rio de Janeiro, 2018. 77p. Dissertação de Mestrado - Departamento de Engenharia Industrial, Pontifícia Universidade Católica do Rio de Janeiro.

O setor elétrico brasileiro é fortemente dependente da energia hidrelétrica e a predição acurada das séries de vazões é essencial para o planejamento e gestão de risco. Recentemente, os modelos híbridos, que combinam técnicas de previsão e pré-processamento de dados, têm se destacado. Entretanto, na literatura, não há consenso sobre a superioridade de previsão destes modelos em relação aos tradicionais (puros). Este trabalho visa contribuir para literatura com a avaliação de performance de previsão e a adequabilidade de modelos puros e híbridos para séries mensais estacionárias e não estacionárias de vazões. Para isso, foram construídos modelos usando as técnicas de previsão de Redes Neurais Artificiais e ARIMA acoplados com as técnicas de pré-processamento de dados Singular Spectrum Analysis (SSA) e Seasonal and Trend decomposition based on Loess (STL). Como resultado, este estudo mostra para a série de Belo Monte (estacionária) os modelos puros obtiveram um melhor desempenho, já para a série de Sobradinho (não estacionária) os modelos híbridos foram os melhores.

\section{Palavras-chave}

Modelos híbridos; vazões; forecast; redes neurais artificiais; ARIMA. 


\section{Abstract}

Delfino, Ana Paula Santos; Oliveira, Fernando Luiz Cyrino (Advisor). Hybrid versus Pure Models: an analysis of prediction performance using Brazilian streamflow. Rio de Janeiro, 2018. 77p. Dissertação de Mestrado Departamento de Engenharia Industrial, Pontifícia Universidade Católica do Rio de Janeiro.

The Brazilian electricity sector is strongly dependent on hydropower and the accurate prediction of streamflow series is essential for planning and risk management. Recently, hybrid models, which combine prediction and data preprocessing techniques, have stood out. However, in the literature there is no consensus on the predictive superiority of these hybrid models versus their pure version. This paper aims to contribute to the literature with the evaluation of prediction performance suitability of pure and hybrid models for monthly stationary and non - stationary series of streamflow. For this, models were constructed using Artificial Neural Network and ARIMA forecasting techniques coupled with the Singular Spectrum Analysis (SSA) and Seasonal and Trend decomposition based on Loess (STL) data pre-processing techniques. As a result, this study shows that pure models obtained a better performance for the Belo Monte (stationary series), already hybrid models were the best for the Sobradinho (non-stationary series).

\section{Keywords}

Hybrid models; streamflow; forecast; artificial neural networks; ARIMA. 


\section{Sumário}

1 Introdução 12

1.1. Objetivos 15

1.2. Estrutura da dissertação 15

2 Revisão da literatura 16

3 Metodologia 23

3.1. Modelo Autorregressivo Integrado de Médias Móveis (ARIMA) 23

3.2. Redes Neurais Artificiais (RNA) 25

3.3. Singular Spectrum Analysis (SSA) 27

3.4. Seasonal and Trend decomposition based on Loess (STL) 30

3.5. Design do experimento e métricas de avaliação de 33 performance

4 Análise dos dados e modelos propostos $\quad 40$

4.1. Modelos propostos $\quad 43$

4.1.1. Modelos propostos Belo monte 44

4.1.2. Modelos propostos Sobradinho 51

4.2. Resultados e discussão dos modelos propostos 59

4.2.1 Resultados e discussão dos modelo de Belo Monte 59

4.2.2. Resultados e discussão dos modelo de Sobradinho 61

5 Conclusão e sugestões de trabalhos futuros 65

6 Referências bibliográficas $\quad 67$

$\begin{array}{ll}\text { Anexo A } & 73\end{array}$

$\begin{array}{ll}\text { Anexo B } & 77\end{array}$ 


\section{Lista de figuras}

Figura 1 - Ciclo iterativo de Box-Jenkins 24

Figura 2 - RNA típica de 3 camadas 26

Figura 3 - Fluxo de construção dos modelos puros $\quad 35$

Figura 4 - Fluxo de construção dos modelos híbridos 37

Figura 5 - Série histórica de vazões Sobradinho e Belo Monte $\left(\mathrm{em} \mathrm{m}^{3}\right)$

Figura 6 - Autovalores da decomposição SSA com $L=12$ do modelo ARIMA de Belo Monte

Figura 7 - Autovetores modelo ARIMA - SSA ( $L=12)$ de Belo Monte

Figura 8 - Matriz W-correlação e Periodograma ARIMA- SSA ( $L=12)$ de Belo Monte

Figura 9 - Séries reconstruídas a partir dos componentes da decomposição de SSA ( $L=12$ ) para o modelo ARIMA-SSA de Belo Monte

Figura 10 - Autovalores da decomposição SSA $(L=12)$ para o modelo RNA de Belo Monte

Figura 11 - Autovetores modelo RNA-SSA $(L=12)$ de Belo Monte

Figura 12 - Matriz W-correlação e Periodograma RNA-SSA $(\mathrm{L}=12)$ de Belo Monte

Figura 13 - Séries reconstruídas a partir dos componentes principais da decomposição de SSA para o modelo RNA-SSA de Belo Monte

Figura 14 - Autovalores da decomposição SSA com $L=12$ para o modelo ARIMA-SSA de Sobradinho

Figura 15 - Autovetores modelo ARIMA-SSA $(L=12)$ de Sobradinho

Figura 16 - Matriz W-correlação e Periodograma ARIMA-SSA ( $L=12)$ de Sobradinho

Figura 17 - Séries reconstruídas a partir dos componentes principais para o modelo ARIMA-SSA $(L=12)$ de Sobradinho

Figura 18 - Autovalores da decomposição SSA com $L=12$ para o modelo RNA-SSA de Sobradinho

Figura 19 - Autovetores modelo RNA-SSA ( $L=12)$ de Sobradinho

Figura 20 - Matriz W-correlação e Periodograma RNA-SSA ( $L=12)$ de Sobradinho 
Figura 21 - Séries reconstruídas a partir dos componentes principais para o modelo RNA-SSA $(\mathrm{L}=12)$ de Sobradinho

Figura 22 - Comparação de Previsão entre os modelos ARIMA para o conjunto de teste de Belo Monte

Figura 23 - Comparação de Previsão entre os modelos RNA para o conjunto de teste de Belo Monte

Figura 24 - Comparação entre os modelos de RNA e ARIMA com melhor desempenho para a série de Belo Monte

Figura 25 - Comparação de Previsão entre os modelos ARIMA para o conjunto de teste de Sobradinho

Figura 26 - Comparação de Previsão entre os modelos RNA para o conjunto de teste de Sobradinho

Figura 27 - Comparação entre os modelos de RNA e ARIMA com melhor desempenho para Sobradinho 


\section{Lista de tabelas}

Tabela 1 - Estatísticas descritivas

Tabela 2 - Resultado do teste de estacionariedade para Belo Monte

Tabela 3 - Modelos ajustados para série de Belo Monte

Tabela 4 - Testes de Aderência dos resíduos dos modelos ARIMA da série de Belo Monte

Tabela 5 - Matriz de Correlação entre as séries reconstruídas a partir dos componentes principais para o modelo ARIMA-SSA ( $L=12)$ de Belo Monte

Tabela 6 - Matriz de Correlação entre as séries reconstruídas a partir dos componentes principais para o modelo RNA-SSA $(\mathrm{L}=12)$ de Belo Monte

Tabela 7 - Modelos ajustados para a série de Sobradinho

Tabela 8 - Testes de Aderência para os resíduos dos modelos ARIMA da série de Sobradinho

Tabela 9 - Matriz de Correlação entre as séries reconstruídas a partir dos componentes principais para o modelo ARIMA-SSA ( $L=12$ ) de Sobradinho

Tabela 10 - Matriz de Correlação entre as séries reconstruídas a partir dos componentes principais para o modelo RNA-SSA ( $L=12$ ) de Sobradinho

Tabela 11 - Resultado das métricas dos Modelos de Belo Monte para o período de teste

Tabela 12 - Resultado das métricas dos Modelos de Sobradinho para o período de teste 


\section{Introdução}

O Setor Elétrico Brasileiro (SEB) foi construído a partir da exploração intensiva do potencial hidráulico do país. Como resultado, a matriz elétrica brasileira hoje é, essencialmente, composta por hidrelétricas (ONS, 2018). Essa primazia impõe cautelosa análise da tendência hidrológica e de seus padrões de variação temporal e espacial, haja vista o significativo impacto que essas alterações podem produzir na sociedade.

Todo planejamento do SEB é fundamentado em uma cadeia de modelos computacionais, nos quais as séries históricas de vazões são utilizadas como dados de entrada. As séries de vazões mensais, por exemplo, destinam-se a modelos de planejamento de médio e longo prazo, destacando-se os seus usos para a geração de energias naturais afluentes ${ }^{1}$ dos subsistemas (Marcato, 2002). As vazões, portanto, se apresentam como as variáveis de decisão mais importantes do sistema. Ao subsidiar a tomada de decisão do SEB, as previsões de vazões subsidiam, igualmente, a segurança no aproveitamento energético, o uso múltiplo da água e controle de cheias. Portanto, a previsão das vazões dos diversos reservatórios do SEB é um tema de extrema importância.

Dada sua importância, diversos trabalhos têm sido realizados na tentativa de melhorar a qualidade das previsões/simulações de vazões brasileiras (Guilhon, Rocha e Moreira, 2007; Spaeth, 2008.; Fan et al., 2014; Santos e Silva, 2014; Teixeira et al., 2015; Britto, Salgado e Beijo, 2016; Siqueira et al., 2018). Estes trabalhos apontam o uso promissor de modelos de inteligência artificial e a combinação diferentes técnicas e modelos para realizar previsões de vazões brasileiras.

\footnotetext{
${ }^{1}$ A energia natural afluente a uma região é a soma das energias naturais afluentes a todas as usinas desta região e energia natural afluente a uma usina é o produto da vazão natural afluente a esta usina pela sua produtividade, considerando que o volume do reservatório esteja a $65 \%$ de seu valor máximo (Marcato, 2002).
} 
Apesar disso, os modelos mais utilizados para previsão de séries hidrológicas são os modelos estatísticos da família Box-Jenkins, modelos tradicionais na análise de séries temporais no domínio do tempo (Box e Jenkins, 1970; Wu, Chau e Fan, 2010; Yaseen et al., 2015). Entre os modelos mais usados para previsão de séries de hidrológicas temos Autorregessivo (AR), Autorregessivo Periódico (PAR), Médias Móveis (MA), Autorregessivo de Médias Móveis (ARMA), Autorregessivo Integrado de Médias Móveis (ARIMA), Autorregessivo Integrado de Médias Móveis Sazonal (SARIMA), e Regressão Linear Múltipla (MLR) (Hipel e McLeod, 1994; Wu, Chau e Li, 2009; Yaseen et al., 2015; Fahimi, Yaseen e El-shafie, 2017).

Uma das premissas fundamentais dos modelos Box-Jenkins é a estacionariedade de segunda ordem ${ }^{2}$. A literatura mostra que nem sempre estes modelos apresentam bom desempenho para capturar não estacionariedade presente em certas séries (Jain e Kumar, 2007; Zhang et al., 2011; Yaseen et al., 2015).

Um das dificuldades de previsão das séries de vazões hidrológicas é a ampla gama de escalas espaciais e temporais, cuja relação inerente é não linear (Maier e Dandy, 2000; Zhang et al., 2011). Com isso, outras abordagens, além dos modelos estatísticos de Box-Jenkins, têm sido desenvolvidas para previsão de séries de hidrologia (Zhang et al., 2011; Yaseen et al., 2015; Zhang et al., 2015; Fahimi, Yaseen e El-shafie, 2017).

As aplicações de inteligência artificial, mais precisamente das técnicas Machine Learning, em hidrologia tem crescido nas duas últimas décadas (Jain e Kumar, 2007; Cheng et al., 2015; Yaseen et al., 2015; Fahimi, Yaseen e El-shafie, 2017) . A motivação para o uso de técnicas baseadas em dados para prever ou simular séries hidrológicas vem justamente da habilidade destes em capturar a complexidade dos dados (Yaseen et al., 2015; Yang et al., 2017). As Redes Neurais Artificias (RNA) são um dos modelos mais utilizados, dado que são modelos muito abrangentes que não supõem nenhuma linearidade da série de dados.

Além disso, modelos híbridos de técnicas estatísticas e Machine Learning têm sido uma tendência nos últimos anos (Napolitano, Serinaldi e See, 2011; Karthikeyan e Nagesh Kumar, 2013; Yaseen et al., 2015; Zhang et al., 2015; Du,

\footnotetext{
${ }^{2}$ Uma série é estacionária quando sua média é constante para todo período t, a variância constante e finita em todo t, e a sua covariância depende apenas do intervalo de tempo e não do instante analisado. Essas características são comumente chamadas de estacionariedade de segunda ordem (Souza e Castro, 2004).
} 
Zhao e Lei, 2017; Fahimi, Yaseen e El-shafie, 2017). Estes métodos têm ganhado popularidade devido ao significativo aumento de desempenho nas previsões de séries complexas, como as de hidrologia.

Entretanto, autores como Zhang et al. (2015) e Du, Zhao e Lei (2017) apontam a construção incorreta de modelos híbridos. Segundo os autores, ao utilizar técnicas de pré-processamento, como Singular Spectrum Analysis (SSA), Wavelet e Empirical Mode Decomposition (EMD), muitos trabalhos fazem primeiro a decomposição da série e depois fazem a separação dos dados em conjuntos de treinamento e teste. Este processo leva informação futura aos dados passados, sendo um experimento de Hindcast ${ }^{3}$, e não um Forecast ${ }^{4}$ (previsão real) como demostram Du, Zhao e Lei (2017) e Zhang et al. (2015), fazendo com que os modelos híbridos apresentem, erroneamente, um desempenho superior à sua versão pura.

Apesar da literatura apresentar diversos estudos que apontam que os modelos híbridos têm desempenho superior à sua versão pura, a maior parte desses trabalhos não apresenta com clareza o framework utilizado para construir os modelos. Com isso, não há consenso na literatura sobre a superioridade dos modelos híbridos frente aos puros com relação a previsão de vazões (Yaseen et al., 2015; Zhang et al., 2015; Du, Zhao e Lei, 2017). Portanto, existe uma lacunana literatura a ser explorado. Com objetivo de reduzir esta lacuna na literatura, este trabalho testa a performance de modelos híbridos e puros utilizando técnicas estatísticas e de Machine Learning, limitando-se a utilizar duas séries de vazões brasileiras, Sobradinho e Belo Monte. Ambas as séries foram escolhidas devido ao fato de suas afluências serem de grande importância para múltiplos usos (geração hidrelétrica, consumo humano, controle de cheias e etc.). Ademais, a série de vazão de Sobradinho é não estacionaria no período testado, já a série de vazões de Belo Monte é estacionária no período testado. O que faz com que este trabalho, adicionalmente, discuta a adequabilidade de modelos puros e híbridos para séries estacionárias e não estacionarias, análise não encontrada na literatura para as vazões brasileiras.

${ }^{3}$ No experimento de Hindcast primeiro os dados são decompostos e depois separados nos conjuntos de treinamento e teste.

${ }^{4}$ No experimento de Forecast primeiro os dados são separados em conjunto de treinamento e teste e depois no conjunto de treinamento é aplicado a decomposição. 


\section{1.}

\section{Objetivos}

(i) Comparar a performance dos modelos puros e híbridos, construídos a partir de modelos ARIMA e RNA acoplados com as técnicas de pré-processamento (Singular Spectrum Analysis) SSA e (Seasonal and Trend decomposition based on Loess) STL, para as séries de vazões Sobradinho e Belo Monte.

(ii) Analisar a adequabilidade de modelos puros e híbridos para séries estacionárias e não estacionárias de vazões.

Como delimitação, cabe ressaltar que, apesar da existência de diversas séries estacionárias e não estacionarias de vazões brasileiras, optou-se por utilizar apenas duas séries de dados, Sobradinho e Belo Monte.

\section{2.}

\section{Estrutura da Dissertação}

Esta dissertação está organizada em cinco capítulos, iniciados por esta Introdução, que aborda a contextualização e justificativa do tema escolhido, bem como os objetivos.

O Capítulo 2 apresenta os estudos mais recentes, desenvolvidos no contexto de séries hidrológicas, utilizando modelos puros e híbridos de RNA e ARIMA, com técnicas de decomposição, como SSA e STL, entre outros.

A seguir, o Capítulo 3 aborda a parte metodológica de cada um dos métodos que serão utilizados neste trabalho, com os detalhes matemáticos pertinentes ao entendimento do leitor, assim como a estrutura do experimento de Forecast realizado, e as métricas de avaliação que serão utilizadas para medir a performance dos modelos.

O Capítulo 4 apresenta a descrição estatística das séries utilizadas neste trabalho. Além disso, o Capítulo mostra o detalhamento dos modelos propostos, os resultados e discussões acerca dos mesmos, ressaltando a comparação de desempenho dos modelos propostos e sua adequabilidade para previsão das séries estudadas.

As considerações finais, incluindo as contribuições do trabalho, e sugestões de continuação do estudo são apresentadas no capítulo 5. Por fim, são listadas as referências bibliográficas utilizadas. 


\section{2}

\section{Revisão da Literatura}

Desde 1970 os modelos estatísticos clássicos, família Box-Jenkins, têm dominado a área de previsão de séries hidrológicas (Box e Jenkins, 1970; Yaseen et al., 2015). Entretanto, estes modelos têm como requisito a estacionariedade de segunda ordem e tem capacidade limitada de capturar os efeitos não lineares nos dados (Zhang et al., 2011; Karthikeyan e Kumar, 2013; Du, Zhao e Lei, 2017). Com isso, outras modelagens têm sido desenvolvidas na literatura de forma a melhorar a previsão das séries hidrológicas.

Nos últimos anos, os modelos de inteligência artificial têm recebido muito destaque, devido ao fato de serem capazes de modelar bem as relações lineares e não lineares das séries hidrológicas (Du, Zhao e Lei, 2017; Fahimi, Yaseen e Elshafie, 2017; Yang et al., 2017). Uma das técnicas de Machine Learning mais usados, a Rede Neural Artificial (RNA) tem tido grande sucesso em várias áreas, e seu uso é crescente em hidrologia (Yassen et al., 2015; Fahimi, Yaseen e El-shafie, 2017). A acurácia de previsão dos modelos puros de Redes Neurais Artificiais para séries mensais de vazões é demonstrada por trabalhos como Armed e Sarma (2007), Cheng (2015), Yang et al. (2017) e Siqueira et al. (2018).

Os modelos clássicos e de inteligência artificial foram comparados por Armed e Sarma (2007). Os autores testaram a acurácia de modelos de RNA, ARMA e Thomas-Fiering ${ }^{5}$ com objetivo de verificar qual modelo consegue reproduzir as caraterísticas estatísticas de longo prazo da série mensal do Rio Pagladia, no Butão. Os resultados do trabalho mostram que o modelo RNA foi oque obteve melhores resultados de previsão.

Um trabalho mais recente, Cheng (2015), mostrou a acurácia dos modelos de Machine Learning (RNA e Support Vector Machine) para previsão das séries mensais de vazões. Utilizando dados do reservatório Xinfengjiang, o autor

\footnotetext{
${ }^{5}$ Este modelo pode ser visto como um modelo $\mathrm{AR}(1)$ não estacionário, foi desenvolvido para permitir a estacionariedade na série de dados. Para mais informações ver Thomas e Fiering (1962).
} 
demonstrou que ambos são satisfatórios para previsão. Outro trabalho recente, que aplica técnicas de Machine Learning para previsões de vazões, é o dos autores Yang et al. (2017). Estes propuseram a comparação de desempenho utilizando técnicas de RNA, Random Forest e Support Vector Regression, incluindo variáveis climáticas entre os regressores, utilizando diversas configurações paramétricas para previsão das vazões de dois reservatórios, um na China e outro nos EUA. A conclusão dos autores é que o modelo de Random Forest obteve o melhor resultado entre os modelos aplicados.

Para as séries brasileiras e vazões, Siqueira et al. (2018) compararam o desempenho de previsão dos modelos de Extreme Learning Machines (ELM), Echo State Networks (ESN), Multilayer Perception (MLP) e PAR (p) para três séries Sobradinho, Furnas e Emborcação. Os autores concluíram que o modelo ELM fez previsões mais acuradas para as séries estudadas.

A quantidade de trabalhos aplicando técnicas de inteligência artificial em hidrologia é bastante expressiva, tanto que algumas revisões da literatura sobre o tema foram realizadas (Maier et al., 2010; Nourani et al., 2014; Yaseen et al., 2015; Fahimi, Yaseen e El-shafie, 2017). Yaseen et al. (2015) apresentam uma revisão da literatura dos modelos de inteligência artificial aplicados a vazões desenvolvidos entre 2000 e 2015. Como a revisão da literatura mais recente dos modelos híbridos de inteligência artificial aplicados na área de hidrologia, Fahimi, Yaseen e El-shafie (2017) atualizam as revisões feitas por Maier et al. (2010), Nourani et al. (2014) e Yaseen et al. (2015). Com isso, daqui em diante, a revisão deste trabalho trará apenas modelos híbridos com técnicas de pré-processamento aplicados a séries de vazões.

Uma forma de melhorar os modelos de Machine Learning é o préprocessamento de dados (Maier e Dandy, 2000). Diversos trabalhos concluem que o uso de técnicas de pré-processamentos de dados faz com que o desempenho dos modelos híbridos seja superior à sua versão pura (Wang et al., 2006; Jain and Kumar, 2007; Guilhon, Rocha e Moreira, 2007; Spaeth, 2008; Wu, Chau e Li, 2009; Peicai et al., 2010; Wu, Chau e Fan, 2010; Napolitano, Serinaldi and See, 2011; Zhang et al., 2011; Latifoğlu, Kişi and Latifoğlu, 2015; Zhang et al., 2015; Du, Zhao e Lei, 2017). Isto ocorre por dois motivos. Primeiro, o pré-processamento de dados pode assegurar que durante o processo de treinamento todas as variáveis 
recebam atenção igual. Segundo, o pré-processamento é capaz de aumentar a eficiência do algoritmo de treinamento (Dawson e Wilby, 2001; Zhang et al., 2011; Fahimi, Yaseen e El-shafie, 2017).

Na literatura, os modelos híbridos, construídos a partir de técnicas de préprocessamento, podem representar dois tipos de experimentos distintos. O primeiro é referido na literatura como "Hindcast experiment" (Zhang et al., 2015) ou "Inner experiment" (Du, Zhao e Lei, 2017) e "Forecast experiment" (Pecai et al., 2010; Karthikeyan e Nagesh Kumar, 2013; Zhang et al., 2015) ou "Outer experiment" (Du, Zhao e Lei, 2017). A diferença entre os dois é que no primeiro os dados são decompostos e depois separados nos conjuntos de treinamento e teste, já no segundo ocorre primeiro a divisão dos conjuntos e depois aplica-se a decomposição.

Comparando modelos de RNA puros e híbridos (com diversas técnicas de pré-processamento) Wang et al. (2006) avaliaram a influência do préprocessamento de dados na acurácia da previsão. Os autores aplicaram transformação logarítmica, padronização, redimensionamento, dessazonalização e combinações desses métodos na série de vazões do rio chinês Yellow. Como resultado, os autores indicam que a dessazonalização dos dados sem o redimensionamento é o método de pré-processamento mais eficiente entre todos os testados.

Tentando unir asvantagens dos modelos Box-Jenkins e do modelo de RNA, Jain e Kumar (2007) combinaram os modelos de RNA e Autogressivo (AR) e aplicaram nas séries mensais do Rio Colorado, nos EUA. O modelo híbrido proposto pelos autores parte de passos convencionais de séries temporais (como dessazonalização e remoção de tendência) e pela modelagem gradual em uma estrutura de RNA para capturar a não linearidade. Os resultados sugerem que o modelo híbrido de RNA é mais robusto para modelar séries complexas do que o modelo AR puro.

Para as vazões brasileiras temos o estudo de Guilhon, Rocha e Moreira (2007), estes aplicaram metodologias híbridas combinando tanto técnicas de inteligência artificial e modelos estocásticos diversos para séries de vazões brasileiras das usinas hidrelétricas de Itaipu, São Simão, Salto Osório e Foz do Areia. Fazendo previsões semanais e diárias os autores concluíram que os modelos híbridos obtiveram o melhor desempenho. Spaeth (2008) analisou a performance 
de modelos híbridos e puros para previsão das séries diárias de vazões do rio Itajaí Açu e concluiu que os modelos híbridos foram os mais eficientes em termos de previsão.

Utilizando as séries de vazões mensais dos reservatórios chineses Xiangjiaba e Danjiangkou, Wu, Chau e Li (2009) desenvolveram modelos ARMA, K-NearestNeighbors (KNN), RNA, e Crisp Distributed Artificial Neural Networks (CDANN) com as técnicas de pré-processamento Singular Spectrum Analysis (SSA) e o modelo de Médias Móveis (MA) de Box e Jenkings. Os modelos desenvolvidos foram aplicados para previsão um, três, seis e doze meses à frente das séries de vazões dos reservatórios Xiangjiaba e Danjiangkou. Como resultado, os autores encontraram que os modelos com pré-processamento de dados obtiveram melhor resultado que os modelos em suas versões puras.

Peicai et al. (2010) realizaram a comparação de modelos híbridos de Empirical Mode Decomposition (EDM) e RNA utilizando experimentos de Hindcast e Forescast em séries climáticas não estacionárias. Os autores concluíram que a decomposição melhora a qualidade das previsões.

Três modelos benchmark (RNA, KNN, e Regressão Linear) e o modelo de Redes Neurais Artificiais Modular (MANN, em inglês) em suas versões puras e híbridas foram comparados por Wu, Chau e Fan (2010). Os modelos híbridos foram construídos a partir de três técnicas, Análise de Componentes Principais (PCA), SSA e MA de Box e Jenkigs. Os autores concluíram que SSA foi a melhor técnica de pré-processamento e que o MANN híbrido com SSA obteve o melhor desempenho.

O modelo clássico da família Box-Jenkins, ARIMA, foi comparado com sua versão híbrida (ARIMA-SSA) e com o modelo Singular Spectrum Analysis- Linear Recurrent Formulae (SSA - LRF) por Zhang et al. (2011). Utilizando dados de escoamento anual de dois reservatórios na China os autores concluíram que os modelos híbridos obtiveram melhor performance.

Napolitano, Serinaldi e See (2011), utilizando séries de vazões diárias dos rios Potomac e Clark Fork, EUA, realizaram um experimento de Hindcast. Os autores, utilizando EMD (Empirical Mode Decomposition) como técnica de préprocessamento, desenvolveram modelos híbridos e puros de RNA com pesos de inicialização randômicos. Mesmo com diversas métricas de avaliação, os autores 
não chegam a resultados conclusivos sobre qual modelo tem melhor performance para o Rio Potomac. Entretanto, para o Rio Clark Fork o modelo híbrido (RNAEDM) apresentou resultados estatisticamente melhores que sua versão pura.

Outro trabalho que estuda modelos híbrido é o de Karthikeyan e Kumar (2013). Os autores desenvolveram modelos híbridos, uma combinação de ARMA e decomposição Wavelet e EMD, para seis séries mensais não estacionárias. E concluíram que os modelos híbridos têm uma boa performance para prever as séries.

Santos e Silva (2014) aplicaram um modelo híbrido de RNA e Wavelet nas séries de vazões diárias da hidrelétrica de Sobradinho, no rio São Francisco, Brasil. Os autores concluíram que os modelos híbridos têm melhor performance. Fan et al. (2014) também analisaram as vazões do rio São Francisco, aplicando previsões combinadas para as vazões horárias de Três Marias. Como resultados os autores apontam que as previsões combinadas foram melhores que as previsões realizadas pelos modelos puros.

Outro trabalho que desenvolve modelos híbridos para as séries de vazões brasileiras é o de Teixeira et al. (2015). Os autores utilizando vazões mensais no posto 266 (Itaipu) localizado no rio Paraná, Brasil, construíram modelos ARIMA e RNA puros acoplados com decomposição de Wavelet. Os autores concluíram que os modelos híbridos obtiveram um desempenho melhor que os puros. Brito, Salgado e Beijo (2016) aplicaram previsões combinadas e puras para as vazões de algumas usinas da Bacia do Rio Grande, utilizando Redes Neurais Artificiais e programação genética. Os autores concluíram que a estratégia de combinar previsões obtidas através de diferentes modelos possibilitou, na maioria das vezes, a diminuição do erro relativo médio.

Latifoğlu, Kişi e Latifoğlu (2015) comparam um modelo puro de RNA com um hibrido de RNA e SSA para previsão de séries vazões, não lineares e não estacionarias, do Rio Kizilirmak, Turquia. Os autores ressaltam a importância dos modelos híbridos, mostrando sua performance superior com relação ao modelo puro.

Ao mesmo tempo Zhang et al. (2015) questionam a superioridade dos modelos híbridos sobre os puros e chegam a conclusão oposta a Latifoğlu, Kişi e Latifoğlu (2015). Utilizando dados mensais das vazões de Cuntan e Yichang, os 
autores desenvolvem modelos ARMA e RNA puros e híbridos com as técnicas de pré-processamento (SSA, EDM e Wavelet). Além disso, realizando experimentos de Hindcast e Forecast os autores demostram que o modo como os modelos híbridos são construídos pode levar informações futuras aos dados do passado. Como resultado, os autores mostram que os modelos puros têm melhor desempenho nas previsões e que decompor as séries utilizando técnicas de pré-processamento antes de separar os conjuntos de treinamento e teste leva informações futuras aos dados. Com isso, os autores apontam a necessidade de mais estudos sobre os efeitos da forma de aplicação de técnicas de pré-processamento.

Como apontado por Zhang et al. (2015) e verificado neste trabalho a maior parte dos estudos utilizando modelos híbridos não apresentam de forma clara a metodologia de construção dos modelos. Com isso, é difícil identificar se os modelos utilizados são realmente válidos para previsão, isto é, se eles foram construídos sob a forma de experimento de Forecast.

Corroborando com Zhang et al., (2015) Du, Zhao e Lei (2017) apontam que a aplicação de técnicas de pré-processamento na série de dados antes de separar os conjuntos de treinamento e teste - experimento de Hindcast- é uma forma incorreta de construir modelos híbridos para previsão, visto que leva informações futuras aos dados passados. Portanto, um experimento de Hindcast não pode ser utilizado para previsão e nem avaliar o desempenho de modelos de previsão. Com isso, os autores apontam que na literatura corrente a aplicação de técnicas de pré-processamento em modelos híbridos tem sido incorreta. Para verificar sua hipótese os autores utilizam os modelos RNA e SVM puros e híbridos com técnicas de pré-processamentos (SSA e Discrete Wavelet Transform (DWT)). Os autores mostram, utilizando dados hidrológicos da Índia, que modelos construídos via experimento de Hindcast contém informações dos valores futuros fazendo com que os modelos híbridos tenham incorretamente uma melhor performance que os puros, causando grandes erros na prática. Assim como Zhang et al. (2015), Du, Zhao e Lei (2017) apontam o desempenho superior de modelos puros.

Em suma, os modelos de Machine Learning realmente têm se demostrado um caminho promissor para melhorar as previsões de séries hidrológicas. Entretanto, a literatura mostra que a aparente superioridade dos modelos híbridos (com técnicas de pré-processamento) frente aos modelos puros tem sido 
questionada. Não há consenso na literatura sobre o desempenho de modelos híbridos e puros. Dentro deste contexto a discussão sobre a estacionariedade das séries temporais não tem sido destacada. Diante disso, existe uma lacuna na literatura que precisa ser melhor explorado. E é justamente o que se propõe este trabalho: analisar a acurácia de modelos híbridos e puros para previsão de séries mensais de vazões brasileiras, utilizando um experimento de Forecast, e discutir a questão da estacionariedade das séries dentro deste contexto. 


\section{3 Metodologia}

Neste capítulo serão apresentados os conceitos teóricos das técnicas de previsão (Modelo Autorregressivo Integrado de Médias Móveis e Redes Neurais Artificiais) e de pré-processamento de dados (Singular Spectrum Analysis (SSA) e Seasonal and Trend decomposition based on Loess (STL)) que serão aplicadas nesta dissertação. Além disso, será apresentado como os modelos puros e híbridos foram construídos e as métricas utilizadas para comparar a performance dos modelos.

\section{1.}

\section{Modelo Autorregressivo Integrado de Médias Móveis (ARIMA)}

Os modelos da família Box-Jenkins são matematicamente robustos para descrever os processos geradores de diversos tipos de séries temporais dispensando, a priori, o uso de outras variáveis (Box e Jenkins, 1970). Um dos modelos mais conhecidos da família Box-Jenkins é o ARIMA. Este modelo é baseado em três componentes paramétricos lineares: Autorregressivo (AR), Integração (I) e Médias Móveis (MA). Sendo assim, é a junção de dois modelos complementares, AR e MA. O modelo ARMA (p, q) pode ser definido expressado da seguinte forma:

$$
\mathbf{z}_{\mathbf{t}}=\boldsymbol{\theta}_{0}+\phi_{1} \mathbf{z}_{\mathrm{t}-1}+\ldots+\phi_{\mathbf{p}} \mathbf{z}_{\mathrm{t}-\mathrm{p}}+\mathbf{a}_{\mathrm{t}}-\boldsymbol{\theta}_{\mathbf{1}} \mathbf{a}_{\mathbf{t}-\mathbf{1}}-\cdots-\boldsymbol{\theta}_{\mathbf{q}} \mathbf{a}_{\mathbf{t}-\mathbf{q}}
$$

Onde, $Z_{t}$ é o valor da observação no período $t, \theta_{0}$ é o nível constante e $a_{t}$ é o erro aleatório no período $t, \phi_{p}$ e $\theta_{q}$ são, respectivamente, os coeficientes dos polinômios autorregressivos, de ordem $p$, e de média móveis, de ordem $q$. Normalmente, assume-se que os erros são independentes e identicamente distribuídos, com média zero e variância constante, comportando-se como uma série de ruído branco. O modelo ARIMA sazonal contém os componentes 
Autorregressivo, Integração e Médias Móveis para a parte sazonal da série, podendo ser definido como $\operatorname{ARIMA}(p, d, q, P, D, Q)[s]$, sendo $s$ é o período.

O processo para determinar o modelo ARIMA mais adequado para qualquer série segue as etapas apresentadas na Figura 1.

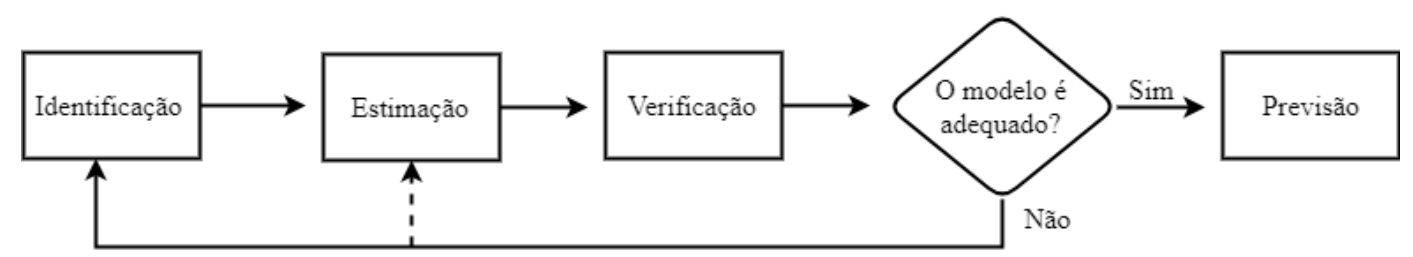

Figura 1 - Ciclo iterativo de Box-Jenkins

Fonte: Autor baseado em Castro e Souza, 2004

O modelo ARIMA baseia-se nas características de linearidade da série temporal e estacionariedade e é apropriado para modelar séries estacionarias e não explosivas. Adicionalmente, o modelo ARIMA pode modelar um processo não estacionário, desde que processo possa se tornar estacionário através de $d$ sucessivas diferenças (Hipel e McLeod, 1994).

A ordem do modelo ARIMA para a série analisada pode ser identificada através da avaliação da significância estatística dos coeficientes da Função de Autocorrelação (FAC) e da Função de Autocorrelação Parcial (FACP). Além disso, a identificação também pode ser feita por Bootstrap, Autocorrelação Inversa e Estendida ( Souza e Castro, 2004; Cyrino Oliveira, Ferreira e Souza, 2014; Fenga, 2017). Para comparar os diversos candidatos identificados com a análise da FAC e FACP os Critérios de Informação (CI) são bastante difundidos. Existem diversos CI e os mais comuns são: BIC (Bayesian Information Criterion), AIC (Akaike Information Criterion) e AICc (Akaike Information Criterion Corrected). O modelo que apresenta o menor valor para o critério de informação previamente escolhido é o mais adequado para a série de dados. Mais informações sobre os critérios de informação podem ser encontradas em Schwarz (1978), Akaike (1974), Sugiura (1978) e Hurvich e Tsai (1991).

Após a etapa de identificação, prosseguimos com a estimação dos parâmetros do modelo estimado. Para isso, podemos utilizar método dos momentos, estimadores de mínimos quadrados e estimadores máxima verossimilhança.

$\mathrm{Na}$ etapa seguinte é necessário verificar se as hipóteses fundamentais dos modelos referente às características dos resíduos (normalidade, homoscedasticidade e independência) são atendidas. Para testar a normalidade, 
testes como Shapiro Wilk e Jarque-Bera podem ser utilizados, já homoscedasticidade pode-se utilizar o teste de Levene e, por fim, para decorrelação serial dos resíduos podemos utilizar o teste de Box-Pierce ou Ljung-Box. Mais detalhes sobres esses testes podem ser encontrados em Cromwell, Labys; Terraza (1994) e Lung e Box (1978).

Se todas as hipóteses fundamentais forem atendidas, o modelo é adequado para previsão. Caso contrário, é necessário fazer ajustes na etapa de identificação e/ou estimação do modelo. Cabe destacar que a condição de normalidade é desejada, e não essencial. Além disso, na etapa de verificação é necessário realizar o teste de sobrefixação, isto é, verificar se o modelo não está superespecificado ou subespecificado, e dessa forma, atender o critério da parcimônia. Entre todos modelos candidatos, o melhor é aquele que apresentar o menor Critérios de Informação. A última etapa da metodologia de Box-Jenkins é a previsão.

\section{2.}

\section{Redes Neurais Artificiais (RNA)}

A Rede Neural Artificial (RNA) é um modelo matemático robusto e não linear de Machine Learning, inspirado na estrutura neural do cérebro (Hopfield, 1988). Ao tentar igualar as características do cérebro (sistema de informações complexo, não-linear e de funcionamento paralelo), os modelos de RNAs têm grande capacidade de "aprender", isto é, de generalizar ou extrair regras automaticamente de conjuntos de dados complexos.

A ideia da RNA é interconectar os dados de entrada, que são recebidos em neurônios específicos, com os dados de saída usando múltiplos neurônios nas camadas ocultas (a rede neural pode ter uma ou mais camadas ocultas), de forma a extrair as informações explicitas e as relações implícitas entre os dados de entrada e saída. O tamanho e a complexidade da rede são resultados do nível de complexidade do processamento da informação.

As RNAs, diferentemente da análise estatística tradicional, não requerem conhecimento prévio do modelo paramétrico para análise. Apenas é necessário que haja uma relação implícita entre os dados da série, mesmo que desconhecida. O processo de aprendizagem das RNA é realizado basicamente a partir de dois grandes paradigmas: aprendizado supervisionado e não supervisionado. 
No aprendizado supervisionado as saídas atuais da RNA são comparadas com as saídas esperadas. Durante esse processo os pesos da rede têm valores inicialmente aleatórios e são ajustados iterativamente pelo algoritmo de aprendizagem via minimização dos erros globais até que se atinja certo nível de precisão. Existem várias regras ou algoritmos de aprendizagem com o objetivo de minimizar os erros. Entre os mais conhecidos estão Feed Forward Back Propagation (FFBP), Radial Basis Function (RBF) e Generalized Regression Neural Network (GRNN).

No paradigma de aprendizado não supervisionado os parâmetros livres da rede neural são repetidamente modificados de acordo com a regra ou algoritmo de aprendizagem. Portanto, a rede não necessita de um conjunto de treinamento para aprender. Neste processo não há minimização dos erros, o algoritmo tem um sistema de monitoramento de desempenho interno, que analisa as regularidades e/ou tendências das entradas, e ajusta automaticamente à rede. O que ocorre neste tipo de aprendizado é a cooperação entre camadas de unidades de processamento, a competição é a base do aprendizado da rede. A competição faz com que apenas os pesos pertencentes às unidades de processamento vencedoras sejam ajustados. As Redes Neurais Artificiais mais conhecidas deste tiposão as Redes de Mapas Auto-Organizáveis, em inglês Self-Organized Map (SOM).

A configuração mais usada e simples para os modelos de RNA é FFBP que contém três camadas (Figura 2).

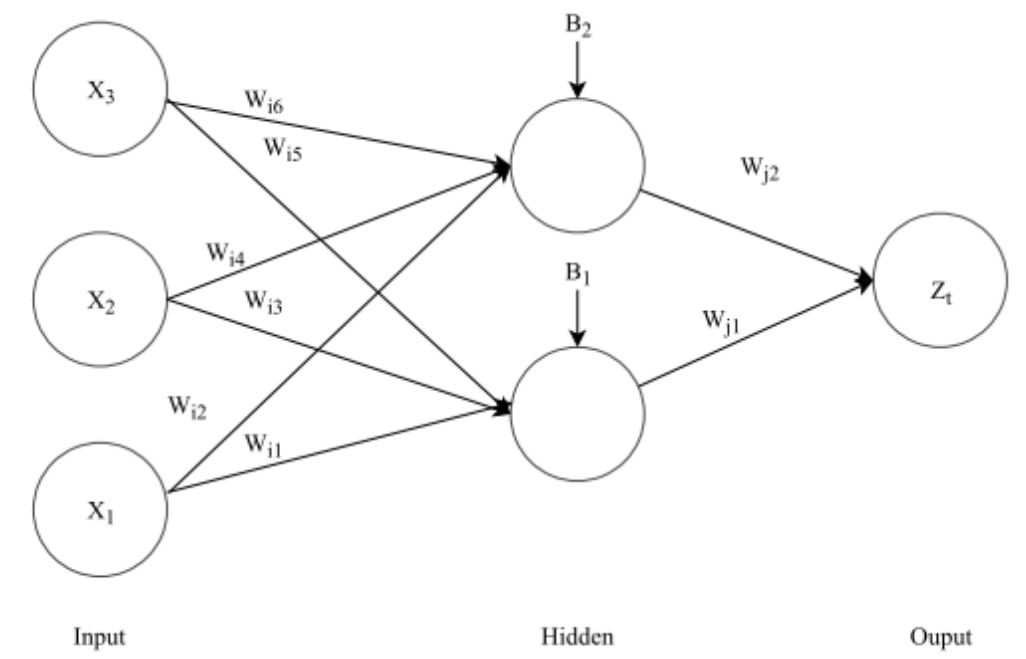

Figura 2 - RNA típica de 3 camadas 
A construção da rede neural Feed Forward pode ser dividida em dois estágios: Feed Forward e Back Propagation. No estágio de Feed Forward os dados de entrada são conectados primeiro a camada de entrada (Input), depois na camada oculta (Hidden) e por último na camada de saída (Output), dessa forma os dados da saída são obtidos. No processo de Back Propagation a conexão entre os pesos e os dados de entrada são calculados pela diferença entre os valores computados e os desejados. Cada neurônio é a soma dos inputs multiplicada pelos pesos associados a cada interconexão, que enviam o valor acumulado para uma função de transferência, gerando assim os dados de saída. Matematicamente, a rede neural artificial pode ser expressa da seguinte forma:

$$
z_{t}=f\left(\sum W X+B\right)
$$

Em que, $X$ é o vetor de dados de entrada, $f$ é a função de transferência, $W$ é o vetor de pesos e $B$ é o vetor de bias e $Z_{t}$ é o vetor de dados de saída. O vetor de pesos é obtido via minimização da soma dos erros quadráticos entre os resultados do modelo e o valor desejado. E o vetor bias tem o efeito de aumentar ou diminuir a entrada líquida da função de ativação, dependendo se ele é positivo ou negativo.

\section{3.}

\section{Singular Spectrum Analysis (SSA)}

A Análise Espectral Singular (Singular Spectrum Analysis - SSA) é uma técnica não paramétrica de análise de dados. A origem da SSA normalmente é associada aos trabalhos de Broomhead e King (1986) e baseia-se exclusivamente nos dados e em princípios de probabilidade, estatística multivariada e conceitos de processamento de sinais (Golyandina et al., 2001).

O objetivo da SSA é decompor a série de dados em conjuntos de componentes independentes e interpretáveis, que representam a tendência, comportamento oscilatório (periódico ou quase-periódico) e os ruídos (Zhang et al., 2011). Uma vez determinados estes componentes, um dos usos da SSA é utilizar alguns desses componentes para reconstruir uma aproximação da série que é utilizada para fazer previsão.

Apesar da técnica de SSA ter várias aplicações podemos destacar filtragem e previsão. O processo de previsão não será discutido neste trabalho, mais detalhes 
sobre esta aplicação podem ser encontrados em Golyandina e Zhigljavsky (2013). O processo de filtragem a técnica de SSA consiste em 4 etapas: Incorporação; Decomposição em Valores Singulares; Agrupamento; e Reconstrução.

$\mathrm{Na}$ etapa de incorporação a série unidimensional $Z_{T}=\left(Z_{1}, Z_{2}, \ldots, Z_{t}\right)$ é representada como uma série multidimensional, cuja dimensão $L$ é chamada comprimento da janela. A série multidimensional é uma sequência de vetores $X_{1}, X_{2}, \ldots, X_{K}$ os quais estão constituídos por elementos da série temporal $Z_{t}$ em que $X_{i}=\left(Z_{i}, \ldots, Z_{i+L-1}\right)^{T} \in \mathbb{R}^{L}$, sendo $K=T-L+1$ (com $\left.1 \leq i \leq K\right)$ o número de vetores coluna ou subséries defasados no tempo. O comprimento da janela $L$ é um parâmetro tal que $2 \leq L \leq N-1$ suficientemente grande, mas não superior a $T / 2$, representando a quantidade de componentes em que a série temporal original é decomposta (Golyandina et al., 2001; Hassani e Ghodsi, 2013). Não existe uma regra universal para a seleção do comprimento da janela, mas segundo Golyandina e Zhigljavsky (2013) a decomposição mais detalhada é obtida quando $L \cong T / 2$. Se L é muito pequeno as frequências serão muito próximas e de difícil separação. Se $L$ é muito grande, a significância estatística dos períodos estimado é comprometida (Zhang et al., 2011). Quando a série é periódica o tamanho da janela pode ser escolhido como um múltiplo do período (Zhang et al., 2011). O resultado da incorporação é a chamada matriz trajetória:

$$
X=\left[X_{1}, X_{2}, \ldots, X_{K}\right]=\left(x_{i j}\right)_{i, j=1}^{L, K}=\left[\begin{array}{cccc}
Z_{1} & Z_{2} & \ldots & Z_{K} \\
Z_{2} & Z_{3} & \ldots & Z_{K+1} \\
\vdots & \vdots & \ddots & \vdots \\
Z_{L} & Z_{L+1} & \ldots & Z_{T}
\end{array}\right]
$$

A matriz de trajetória $X$ é uma matriz de Hankel, ou seja, todos os elementos das diagonais paralelas à diagonal secundária da matriz são iguais. Além disso, a matriz é simétrica e todos os valores das linhas e colunas da matriz $X$ são subséries da série original. O único parâmetro (e muito importante) desta fase é o comprimento da janela.

Na próxima etapa a Decomposição em Valores Singulares (em inglês, SVD) da matriz de trajetória $X$ é realizada (Golyandina et al., 2001). A decomposição vetorial da matriz $S=X X^{T}$ de dimensão $L x L$, gera o conjunto $L$ de autovalores e autovetores. Os autovalores da matriz $S$ podem ser denotados por $\left(\lambda_{1} \geq \cdots \lambda_{L} \geq\right.$ 
0 ) e por $U_{1}, \ldots, U_{L}$ os correspondentes autovetores da matriz $S$. A aplicação do SVD na matriz de trajetória $X$ leva a decomposição desta matriz em uma soma de matrizes:

$$
X=E_{1}+E_{2}+\ldots+E_{L}
$$

Onde, $E_{i}=\sqrt{\lambda_{i}} U_{i} V_{i}^{T}\left(\operatorname{Se} \lambda_{i}=0\right.$, então $\left.E_{i}=0\right)$ e $(i=1,2, \ldots, L)$ são os componentes principais. Estes são matrizes elementares mutuamente ortogonais e de posto unitário (Golyandina et al., 2001).

$\mathrm{Na}$ fase de agrupamento os elementos das matrizes elementares $E_{i}$ são agrupados em $p$ de $L$ componentes principais. Cada um destes grupos concentram os elementos com características semelhantes ou com maior correlação entre si (Golyandina et al., 2001; Hassani e Ghodsi, 2013; Zhang et al., 2015). De acordo com a escolha de $I=\{i 1, \ldots, i p\}$ componentes principais, a matriz de trajetória $X_{I}$ é obtida como:

$$
X_{I}=X_{i 1}+\cdots+X_{i p}
$$

O procedimento de escolha desses grupos $X_{1}, \ldots, I_{i p}$ é chamado de agrupamento das autotriplas e este fornece o último parâmetro da técnica de SSA (Golyandina et al., 2001; Hassani e Ghodsi, 2013; Zhang et al., 2015). O restante das autotriplas $(L-p)$ é definido como termo de erro.

Nesta última fase, reconstrução, cada ip componente selecionado na fase anterior é usado para construir a série temporal. O objetivo da fase de reconstrução, também, é transformar todas as matrizes componentes da matriz $X_{I}$ em uma matriz de Hankel, que pode ser convertida posteriormente em novas séries temporais de tamanho $N$ em um processo chamado média diagonal ou Hankelização. Sendo $Y$ de dimensões $L x K$ com elementos $Y_{i j}, 1 \leq i \leq L$ e $1 \leq j \leq K$, ou seja, os elementos da diagonais paralelas à diagonal secundária $i+j=k+1$, e onde $L^{*}=\min (L, K)$, $K^{*}=\max (L, K)$ e $N=L+K-1$. O processo de Hankelização transforma $Y$ em séries temporais reconstruídas $y_{1}, \ldots, y_{N}$, pela seguinte formula: 


$$
y_{k}=\left\{\begin{array}{cc}
\frac{1}{k} \sum_{p=1}^{k} y_{p, k-p+1} & 1 \leq k \leq L^{*} \\
\frac{1}{L} \sum_{p=1}^{L^{*}} y_{p, k-p+1} & L^{*} \leq k \leq K^{*} \\
\frac{1}{N-k} \sum_{p=k-K *+1}^{N-k+1} y_{p, k-p+1} & K^{*} \leq k \leq N
\end{array}\right\}
$$

A aplicação do procedimento de Hankelização em todos os componentes da matriz (5) resulta em séries temporais $R E C_{k}$ são chamadas de componentes temporais de reconstrução. Com isso, a série inicial pode ser decomposta na soma $k$ de séries:

$$
Z_{t}=X \approx R E C_{1}+\cdots+R E C_{k}
$$

\section{4 .}

\section{Seasonal and Trend decomposition based on Loess (STL)}

O método de Seasonal and Trend decomposition based on Loess (STL), desenvolvido por Cleveland et al. (1990), é um o procedimento de filtragem de dados que decompõe a série temporal em três componentes aditivas: tendência, sazonalidade e resíduo.

$$
Z_{t}=T_{t}+S_{t}+R_{t}
$$

Onde, $Z_{t}$ é a série temporal no instante $t, T_{t}$ é o componente de tendência no instante $t, S_{t}$ é o componente sazonal no instante $t$ e $R_{t}$ resíduo no instante $t$, e $(t=$ $1, \ldots, N)$.

Entre as vantagens do método estão a identificação da mudança do componente sazonal ao longo do tempo, a resposta a tendências não lineares, além de ser robusto na presença de outliers. A ideia do método é aplicar amortecimentos baseados em Regressão Local (Loess Locally Weighted Regression) uma quantidade considerável de vezes gerando estimativas para os componentes de tendência e sazonalidade (Cleveland et al., 1990). Suponha que $X_{t}$ e $Y_{t}$ para $t=1$ em $n$ medidas da variável independente $\mathrm{X}$ e dependente $\mathrm{Y}$, respectivamente. Podemos definir a Regressão Local como uma curva amortecida de uma variável 
independente $Y$ dada uma variável dependente $X$, que pode ser calculada para qualquer valor de $X_{t}$ ao longo da escala de $Y$.

A regressão local, $\hat{g}(x)$, é calculada a partir da escolha de um valor positivo inteiro, $q$. Supondo que $q \leq n$ os valores q de $X_{t}$ (variável dependente) mais próximos de $X$ são selecionados e cada valor recebe um peso de vizinhança baseado na sua distância com relação a $X$. Sendo $\lambda_{q}(X)$ a distância do $q$ valor de $X_{i}$ mais distante de $X$. A função dis pesos é denotada por $W$.

$$
W(u)=\begin{gathered}
\left(1-u^{3}\right)^{3} \operatorname{para} 0 \leq u<1 \\
0 \quad \operatorname{para} u \geq 1
\end{gathered}
$$

O peso da vizinhança para qualquer $X_{i}$ é

$$
v_{i}(X)=W\left(\frac{\left|X_{t}-X\right|}{\lambda_{q}(X)}\right)
$$

Quanto mais próximo $X$ é $X_{t}$, maior peso é o peso recebido. Os pesos reduzem de acordo com a distância de $X$ e no $q$ - valor mais distante de $X$ o peso recebido é zero. O próximo passo é ajustar o polinômio de grau $d$ para os dados com pesos $v_{t}(X)$ em $X_{t}$ e $Y_{t}$. O valor de ajuste polinomial local em $X$ é $\hat{g}(x)$. Quando $d=1$ o ajuste é feito local e linearmente, quando $d=2$ o ajuste é localmente quadrático, e assim sucessivamente.

Se $q<n, \lambda_{q}(X)$ é definido por:

$$
\lambda_{q}(X)=\lambda_{n}(X) \frac{q}{n}
$$

Para usar a regressão local, $d$ e $q$ devem ser escolhidos. Quanto mais $q$ aumenta, mais a função $\hat{g}(x)$ é amortecida. Como q tende para o infinito, $v_{t}(X)$ tende para 1 e $\hat{g}(x)$ tende para um polinômio ordinal quadrático de grau $d$.

A técnica de STL consiste em dois procedimentos recursivos: um loop interno dentro de um loop externo. Em cada uma das passagens pelo loop interno os componentes de sazonalidade e tendência são atualizados, cada loop interno completo consiste em $n_{v}$ passos. Cada uma das passagens o loop externo consiste no loop interno seguido pelo cálculo de pesos robustos. Estes são usados no loop 
interno seguinte para reduzir influências transitórias e qualquer anomalia nos componentes sazonal e de tendência. A execução inicial no loop externo é feita com pesos robustos iguais a 1, e então a passagem $n_{0}$ é realizada (Cleveland et al., 1990).

Cada passagem no loop interno consiste em um amortecimento sazonal que atualiza os componentes sazonais, seguido por amortecimento da tendência, atualizando assim o componente de tendência. Mesmo que não exista $Z_{t}^{k+1}$ os componentes $T_{t}^{k+1}$ e $S_{t}^{k+1}$, ou seja, os competentes no passo $k+1$, podem ser calculados utilizando os seis passos a seguir:

Passo 1 - Remoção da tendência, detrending: a tendência da série é calculada $\left(Z_{t}-T_{t}^{k+1}\right)$. Se $Z_{t}$ é um dado faltante em um particular período, então a série sem tendência para este instante não existirá.

Passo 2 - Amortecimento dos ciclos das subséries: a cada ciclo das subséries sem tendência o amortecimento ocorre via regressão local com $q=n_{s}$ e $d=1$, onde $n_{s}$ é o parâmetro de amortecimento. Os valores amortecidos são computados em todos os períodos, incluindo aqueles com valores faltantes. A coleção dos valores de todos os amortecimento dos ciclos das subséries é temporariamente uma série sazonal, $C_{t}^{k+1}$, contendo $N+2 n_{p}$ valores, onde $-n_{p}+1 \leq t \leq N+n_{p}$.

Passo 3 - Filtragem low-pass dos ciclos das subséries amortecidos: um filtro de baixa passagem é aplicado a $C_{t}^{k+1}$. O filtro consiste na média móvel de tamanho $n_{p}$ (número de observações em cada ciclo do componente sazonal), seguidos por outra média móvel de tamanho 3, seguido por amortecimento via regressão local com $d=1$ e $q=n_{l}$, onde $n_{l}$ é o parrâmetro para o filtro low-pass.

Passo 4 - Remoção da tendência dos ciclos das subséries amortecidas: o componente sazonal do $(\mathrm{k}+1)$ loop é $S_{t}^{k+1}=C_{t}^{k+1}-L_{t}^{k+1}$ para $t \mid(t=1,2, \ldots, N)$. $L_{t}^{k+1}$ é subtraida para prever o impacto da baixa frequência no componente sazonal.

Passo 5 - Dessazonalização: a dessazonalização é realizada via remoção do componente de sazonalidade da série, isto é, $Z_{t}-S_{t}^{k+1}$. Se $Z_{i}$ é um dado faltante em um período particular, então a série sem tendência para este instante não existirá.

Passo 6 - Amortecimento da tendência: as séries dessazonalizadas são amortecidas localmente com $q=n_{t}$ e $d=1$, onde $n_{t}$ é o parâmetro de amortecimento do componente de tendência. Os valores amortecidos são computados em todos os períodos $t \mid(t=1,2, \ldots, N)$, mesmo na ausência de valores. O componente sazonal do loop $k+1, T_{t}^{k+1}$ para $1 \leq t \leq N$. 
No loop interno os componentes $T_{t}$ e $S_{t}$ são encontrados. Então para encontrar o resíduo basta modificar a equação 8:

$$
R_{t}=Z_{t}-T_{t}-S_{t}
$$

Ao contrário dos componentes $T_{t}$ e $S_{t}, R_{t}$ não pode ser encontrado na ausência de $Z_{t}$. A robustez dos pesos reflete quão extremo $R_{t}$. Um outlier nos dados resulta em um resíduo muito grande, $\left|R_{t}\right|$, que terá um peso muito pequeno ou zero. Sendo $h=6$ mediana $\left(\left|R_{t}\right|\right)$, a robustez do peso em $t$ é $p_{t}=B\left(\frac{\left|R_{t}\right|}{h}\right)$, onde $B$ é o peso da função:

$$
B(u)=\begin{gathered}
\left(1-u^{2}\right)^{2} \operatorname{para} 0 \leq u<1 \\
0 \quad \operatorname{para} u>1
\end{gathered}
$$

Com isso, o loop interno é repetido. Mas no amortecimento dos passos 2 e 6 o peso da vizinhança, para o valor no período $t$, é multiplicado pelo peso de robustez $\left(p_{t}\right)$. As iterações de robustez do loop externo são realizadas $n_{0}$ vezes. Em cada período o loop interno inicia com $T_{t}^{0} \neq 0$, exceto para o passo inicial onde $T_{t}^{0}=0$, o valor que dever ser usado é o componente de tendência encontrado no passo 6 do loop interno (Cleveland et al., 1990).

\section{5.}

\section{Design do experimento e Métricas de avaliação de performance}

Neste trabalho foram desenvolvidos modelos híbridos e puros para as séries de vazão mensais de Sobradinho e Belo Monte, as séries históricas contêm dados de janeiro 1931 até dezembro de 2015, ambas são disponibilizadas pelo ONS (2018), responsável pela política operacional do sistema hidroelétrico interconectado. Entretanto, neste trabalho optou-se por utilizar apenas parte da série histórica, a série de vazões de Belo Monte utilizada, correspondem ao período 1971-2015, já Sobradinho correspondem ao período 1951-2015, visto que estes períodos mantem a característica de estacionariedade da série histórica complete. $\mathrm{O}$ modelo puro foi construído utilizando duas etapas (Figura 3): 
Etapa P1 - Separação dos conjuntos: a série original de vazões $\left(Z_{t}\right)$ é dividida em dois conjuntos, treinamento e teste. Na série de sobradinho o conjunto de treinamento corresponde ao período de janeiro de 1951 até junho de 2007 (678 observações), já para a série de Belo Monte o mesmo conjunto corresponde janeiro de 1971 até junho de 2007 (438 observações). O conjunto de teste, de ambas as séries, corresponde ao período entre julho de 2007 e dezembro de 2015, totalizando 102 observações. O tamanho de conjunto de teste foi escolhido com base nas proporções utilizadas na literatura, que, em geral, varia entre $10 \%$ e $25 \%$ do total de dados (Zhang et al., 2011; Karthikeyan e Kumar, 2013; Du, Zhao e Lei, 2017).

Após a divisão dos conjuntos, o conjunto de treinamento é transformado utilizando duas técnicas, normalização (a amplitude dos dados foi ajustada para variar entre 0 e 1) nos modelos RNA e transformação de Box-Cox (Box e Cox, 1964) nos modelos ARIMA.

Neste trabalho a transformação de Box-Cox foi aplicada nos modelos ARIMA utilizando a função BoxCox.lambda, do pacote Forecast do software R, com o método loglik (neste método o lamba é escolhido de forma a maximizar o logaritmo da verossimilhança do modelo linear ajustado) sendo a série inteira de dados (conjunto de treinamento e teste) utilizada para a escolha do lambda, a transformação foi aplicada para ajudar a atender os pressupostos do modelo ARIMA (como resíduos descorrelatados, homoscedasticidade e etc) e garantir que as vazões sejam sempre positivas.

Já a aplicação da normalização foi aplicada nos modelos RNA utilizando a equação $\frac{Z_{t}-\min \left(Z_{t}\right)}{\max \left(Z_{t}\right)-\min \left(Z_{t}\right)}$ para que todas as observações recebam igual atenção no processo de treinamento da rede, tal como feito em Cheng (2015) e Latifoğlu, Kişi e Latifoğlu (2015).

Etapa P2 - Ajuste dos modelos e Previsão: na segunda etapa o modelo é ajustado para o conjunto de treinamento, de acordo com o método escolhido seguindo as etapas apresentadas na seção 3.1 e 3.2. No caso dos modelos ARIMA, a identificação da ordem dos modelos foi feita através da Função de Autocorrelação (FAC) e da Função de Autocorrelação Parcial (FACP), escolhendo o modelo mais parcimonioso possível. O número de defasagens autorregressivos e de médias móveis nos modelos ARIMA foi escolhido entre zero e doze. Os modelos RNA foram ajustados por tentativa e erro e tem uma única camada oculta $\mathrm{O}$ máximo de 
defasagens autorregressivos escolhido também foram doze, o número de neurônios na camada oculta foi escolhido entre 1 e 10, sendo o menor RMSE o critério de escolha do número de neurônios na camada oculta.

Entre os modelos candidatos os modelos escolhidos, tanto para RNA quanto para ARIMA, foram aqueles que obteveram o menor RMSE. Com o melhor modelo foram realizadas previsões para os $k$ passos à frente (neste trabalho $k=102$ ), isto é, para todo o conjunto de teste.

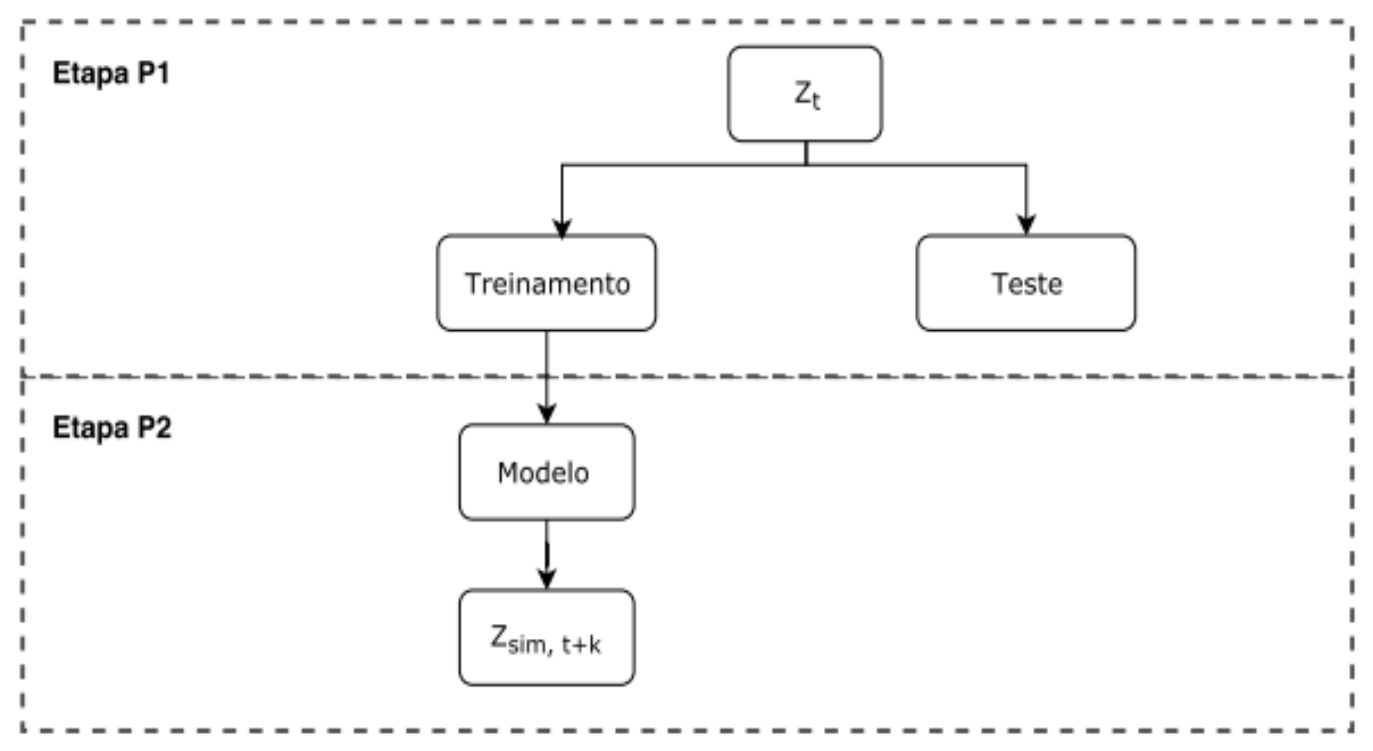

Figura 3 - Fluxo de construção dos modelos puros

Os modelos híbridos deste estudo foram construídos de forma semelhante aos trabalhos de Karthikeyan e Nagesh Kumar (2013), Zhang et al. (2015) e Du, Zhao e Lei (2017). Isto é, primeiro faz-se a separação dos conjuntos em treinamento e teste, e depois a técnica de pré-processamento é aplicada no conjunto de treinamento. $\mathrm{O}$ experimento realizado neste trabalho pode ser visto na Figura 4. A construção dos modelos híbridos pode ser dividida nas etapas abaixo:

Etapa H1 - Separação dos conjuntos: a etapa 1 de construção dos modelos híbridos é exatamente igual ao dos modelos puros.

Etapa H2 - Decomposição e Reconstrução: nesta etapa o conjunto de treinamento é decomposto em $u$ níveis de acordo com a técnica de processamento escolhida tanto para os modelos ARIMA quanto para os modelos de RNA. Quando aplicada a técnica STL a série é decomposta em 3 componentes, $P C_{1, \text { Train }}$, $P C_{2, \text { Train }}, P C_{3, \text { Train }}$, representando, respectivamente, a tendência, resíduos e 
sazonalidade. Cabe destacar que a série de sazonalidade foi considerada como determinística. Desta forma, o componente de sazonalidade $\left(P C_{3, T r a i n}\right)$ não é modelado, o valor correspondente a sazonalidade de cada mês foi apenas adicionado no mês ao qual desejava-se prever. Usando a técnica de SSA, com $u=$ $L$, as janelas $L$ foram testadas com tamanho 2, 3 e 12 . A escolha do tamanho 12 como janela se deve ao fato da série ser mensal (Du, Zhao e Lei, 2017), já para a janela 2 e 3 foram escolhidas por serem as menores possíveis.

A partir dos $u$ componentes foram reconstruídas as séries $R E C i$. Com as janelas de tamanho 2 e 3, o número de séries reconstruídas é igual ao número de componentes, ou seja, $i=u$. Para a janela 12 as séries reconstruídas foram criadas utilizando os componentes principais da decomposição SSA. Essa análise foi feita utilizando a representatividade do autovalor na construção da série, os gráficos dos autovalores pareados e a matriz de correlações ponderadas dos componentes autovetores. Identificando os componentes principais estes foram agregados de acordo com o padrão de variação temporal, gerando assim as séries reconstruídas $R E C i, \operatorname{com} i<u$.

Etapa H3 - Ajuste dos modelos e Previsão: a etapa H3 é semelhante a etapa P2, do modelo puro. Entretanto, nesta etapa é ajustado um modelo para cada uma das séries reconstruídas $(R E C i)$ e a previsão para cada $k$ passo à frente é somada ao longo dos componentes, formando um único valor para cada $k$ instante previsto. Outra opção seria juntar as séries reconstruídas em uma única série e ajustar apenas um modelo assim como Du, Zhao e Lei (2017), porém optou-se por modelar cada componente assim como Karthikeyan e Nagesh Kumar (2013) e Zhang et al. (2015). 


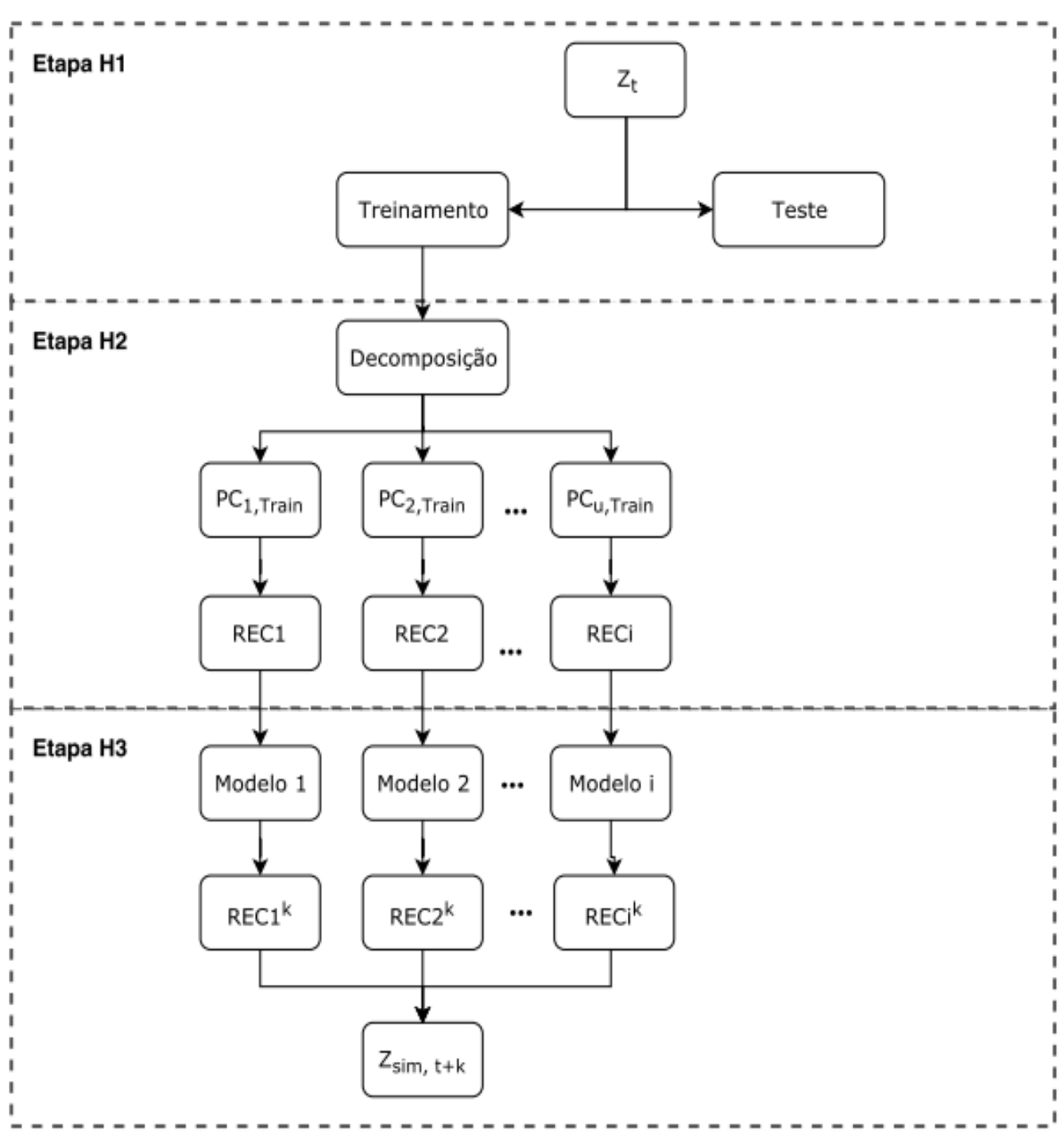

Figura 4 - Fluxo de construção dos modelos híbridos

Neste trabalho serão utilizadas quatro métricas para avaliar a performance dos modelos: Raiz Quadrada do Erro Quadrático Médio (RMSE), Erro Médio Absoluto Percentual (MAPE), Coeficiente de eficiência de Nash-Sutcliffe (NSE) e Coeficiente de Eficiência de Kling-Gupta (KGE). Em todas as métricas apresentadas $Z_{\text {sim,t }}$ e $Z_{\text {obs,t }}$ são os respectivos valores previstos para o conjunto de teste, utilizando o conjunto de treinamento, e observados para as vazões durantes os $k$ meses da série de teste. Com isso, $\bar{Z}_{\text {sim,t }}$ e $\bar{Z}_{o b s, t}$ são os valores médios previstos e observados para as vazões para o $k$ meses da série de teste.

O RMSE é uma das métricas mais comuns de se avaliar modelos de previsão. No cálculo, considera-se a raiz do erro quadrático médio, o que faz com que os erros 
grandes sejam bastante penalizados. Assim, o RMSE é mais sensível aos erros nas vazões máximas. Quanto menor o RMSE melhor é a performance do modelo.

$$
R M S E=\sqrt{\frac{\sum_{t=1}^{k}\left(Z_{s i m, t}-Z_{o b s, t}\right)^{2}}{k}}
$$

O MAPE mede a diferença percentual entre os valores simulados e observados. É o método mais comum, em séries temporais, para se verificar a acurácia de um modelo. Quanto menor o MAPE melhor desempenho tem o modelo.

$$
M A P E=\frac{100}{k} \sum_{t=1}^{k}\left|\frac{Z_{o b s, t}-Z_{s i m, t}}{Z_{o b s, t}}\right|
$$

O Coeficiente de eficiência de Nash-Sutcliffe (NSE) determina a magnitude da variância residual (ruído) comparada com a variância dos dados, sendo bastante sensível a erros em vazões máximas (Nash e Sutcliffe, 1970). É um dos critérios estatísticos mais importantes para aferir e quantificar o poder preditivo de modelos para séries hidrológicas (Moriasi et al., 2007). O NSE é um indicador que pode assumir valores entre o infinito negativo e 1. Quanto mais próximo de 1 mais acurado é o modelo. Se o NSE é igual a 1 significa que o modelo representa perfeitamente os dados observados. NSE igual a zero indica que o modelo faz previsões tão acuradas quanto a média dos dados ( Nash and Sutcliffe, 1970; Moriasi et al., 2007).

$$
N S E=1-\frac{\sum_{t=1}^{k}\left(Z_{o b s, t}-Z_{s i m, t}\right)^{2}}{\sum_{t=1}^{k}\left(Z_{o b s, t}-\bar{Z}_{s i m, t}\right)^{2}}
$$

De acordo com Moriasi et al. (2007) modelos com NSE menor ou igual a 0,5 são insatisfatórios para previsão, já modelos com NSE maior que 0,5 podem ser considerados satisfatórios. Ademais, NSE entre 0,65 e 0,75 indica que o modelo possui boa performance e valores acima de 0,75 indicam um excelente desempenho preditivo do modelo. 
O Coeficiente de Eficiência de Kling-Gupta (KGE) é uma versão aprimorada do NSE e é capaz de evitar algumas limitações apresentadas pelo NSE. Visto que decompõe o NSE em três componentes independentes para representar a correlação linear entre os dados observados e previstos $(r)$, a variabilidade $(\alpha)$ e viés com relação à média $(\beta)$ e isso faz com que haja uma melhoria na estimação do erro performado. Os valores ideias para os componentes do KGE são $r=1, \alpha=$ 1 e $\beta=1$, entretanto o $\mathrm{KGE}$ assume valores entre $(-\infty, 1]$, valores mais próximos de 1 representam um melhor ajuste do modelo (Gupta et al., 2009).

$$
K G E=1-\sqrt{(1-r)^{2}+(1-\alpha)^{2}+(1-\beta)^{2}}
$$

Onde $\alpha=\sigma_{\text {sim }} / \sigma_{o b s}$ e $\beta=\mu_{\text {sim }} / \mu_{\text {obs }}, \sigma_{\text {sim }}$ e $\mu_{\text {sim }}$ são, respectivamente, o desvio padrão e a média das simulações, e $\sigma_{o b s}$ e $\mu_{o b s}$, respectivamente, o desvio padrão e a média dos valores observados. Assim como NSE, KGE maior que 0,5 podem ser considerados satisfatórios, KGE entre 0,65 e 0,75 indica que o modelo possui boa performance e valores acima de 0,75 indicam um excelente desempenho preditivo do modelo (Moriasi et al., 2007). 


\section{4}

\section{Análise dos dados e Modelos Propostos}

Este capítulo apresenta a descrição estatística e a motivação da escolha das séries de vazões naturais de Sobradinho e Belo Monte, o detalhamento dos modelos desenvolvidos a partir das técnicas descritas no capítulo 3. Além dos resultados e discussões acerca dos mesmos, ressaltando a comparação de desempenho dos modelos propostos e sua adequabilidade para previsão das séries estudadas.

As vazões naturais afluentes aos reservatórios correspondem àquelas que ocorreriam em uma seção do rio, caso não houvesse a operação de reservatórios a montante, nem a vazão evaporada pelos lagos artificiais, nem mesmo retiradas de água consumidas com abastecimento e irrigação a montante. Em síntese, a vazão provida pela própria natureza. Uma característica importante de uma série de vazão é a estacionariedade. Uma série temporal é estacionária se as características do processo estocástico gerador da série não se alteram no decorrer do tempo. Portanto, a estacionariedade da série foi um dos critérios para a escolha das séries utilizadas neste trabalho.

Dada a importância da estacionariedade, este trabalho optou por testar a estacionariedade de todas 179 séries das vazões, utilizando os dados de janeiro de 1931 até dezembro de 2015, existentes no Brasil, de forma a identificar as séries estacionárias e não estacionárias. O teste de Mann-Kendall, que avalia mudanças graduais na tendência, é um dos principais testes para avaliar a estacionariedade de séries hidrológicas (Hirsch, Slack e Smith, 1982; Yue, Pilon e Cavadias, 2002; Kundzewicz e Robson, 2004; Hamed, 2008; Rougé, Ge e Cai, 2013). Assim como Zhang et al. (2001), Serinaldi, Kilsby e Lombardo (2018) e Cheng, Li e Feng (2018) a estacionariedade neste trabalho foi testada utilizando o teste não paramétrico Mann-Kendall (Mann, 1945). Esta análise mostrou que 131 séries de vazões são não estacionárias, representando cerca de $73 \%$ das séries de vazões brasileiras. Os resultados dos testes de estacionariedade das 179 séries estão no anexo A.

Após a identificação das séries estacionárias e não estacionarias de vazões brasileiras, foram escolhidas a série de vazões naturais de Sobradinho (Posto 169), 
localizada no Rio São Francisco, e Belo Monte (Posto 288), localizada no Rio Xingu. Como verificado através do teste de Mann-Kendall, a série de Sobradinho é não estacionária, já a série de vazões de Belo Monte é estacionária. Adicionalmente, também foi utilizado o teste KPSS para avaliar a presença de raiz unitária nestas duas séries (Kwiatkowski et al.,1992). Este teste também conclui que a série de Sobradinho é não estacionária e que a série de Belo Monte é estacionária.

Além da característica de estacionariedade, a importância das séries para o sistema elétrico brasileiro também foi considerada. A série de vazões naturais do rio São Francisco e do rio Xingu são importantes devido ao uso múltiplo de suas águas. Isto é, além da geração hidrelétrica, a água desses rios também é utilizada para irrigação, consumo humano e controle de cheias, o que reforça a necessidade de uma ótima política operacional, que inclui a previsão acurada destas séries. A Figura 5 mostra as séries utilizadas neste trabalho, a série mensal de vazões de Belo Monte, correspondem ao período 1971-2015, já Sobradinho correspondem ao período 1951-2015, ambas são disponibilizadas pelo ONS, responsável pela política operacional do sistema hidroelétrico interconectado. A estação chuvosa, em ambas as séries, inicia-se aproximadamente em dezembro e termina em abril. Os meses remanescentes representam a estação seca. As maiores afluências são observadas de fevereiro a abril. 

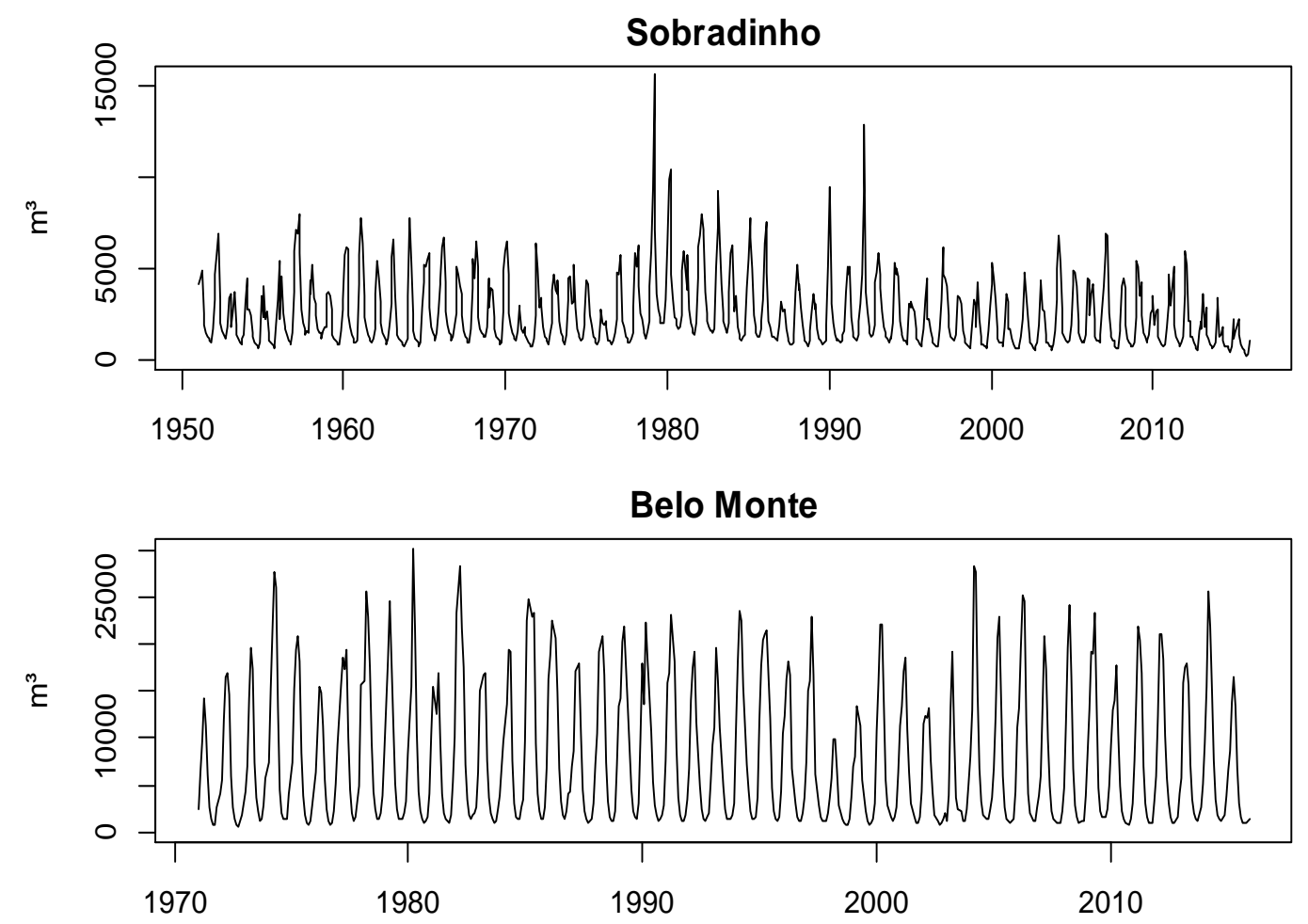

Figura 5 - Série histórica de vazões Sobradinho e Belo Monte (em m³)

A Tabela 1 apresenta algumas das estatísticas mais importante para cada uma das séries analisadas (média, desvio padrão, mediana, curtose, simetria, coeficiente de variação, mínimo, máximo e percentis). É possível notar que todas as medidas entre os as vazões diferem substancialmente. As vazões de Belo Monte apresentam valores superiores para todas estatísticas, exceto para assimetria. Para a série de Belo Monte o conjunto de treinamento contém tanto o máximo como o valor mínimo observado na série histórica. Entretanto, no conjunto de treinamento da série de Sobradinho o valor mínimo é maior que o valor mínimo observado na série histórica, isso pode fazer com que os modelos ajustados tenham dificuldade de prever as vazões baixas. 
Tabela 1 - Estatísticas descritivas

\begin{tabular}{|l|c|c|c|c|c|c|}
\hline \multirow{2}{*}{ Estatística } & \multicolumn{3}{|c|}{ Belo Monte } & \multicolumn{3}{c|}{ Sobradinho } \\
\cline { 2 - 7 } & Toda & Treinamento & Teste & Toda & Treinamento & Teste \\
\hline Mínimo & 641 & 641 & 782 & 227 & 506 & 227 \\
\hline $1^{\circ}$ Quartil & 1,734 & 1,843 & 1,541 & 1,108 & 1,158 & 793 \\
\hline Mediana & 4,822 & 4,862 & 4,765 & 1,773 & 1,844 & 1,262 \\
\hline Média & 7,945 & 8,012 & 7,654 & 2,491 & 2,599 & 1,775 \\
\hline $3^{\circ}$ Quartil & 13,382 & 13,372 & 13,481 & 3,464 & 3,609 & 2,280 \\
\hline Máximo & 30,200 & 30,200 & 25,525 & 15,676 & 15,676 & 5,948 \\
\hline Desvio padrão & 7,259 & 7,293 & 7,140 & 1,885 & 1,933 & 1,326 \\
\hline $\begin{array}{l}\text { Coeficiente de } \\
\text { variação }\end{array}$ & 0.91 & 0.91 & 0.93 & 0.76 & 0.74 & 0.75 \\
\hline Assimetria & 0.89 & 0.90 & 0.85 & 1.77 & 1.74 & 1.31 \\
\hline
\end{tabular}

\section{1.}

\section{Modelos propostos}

Para ajustar os modelos foi o utilizado o software $\mathrm{R}$ e os pacotes ASTSA (Stoffer, 2017), STATS (R Core Team, 2017), Rssa (Golyandina e Korobeynikov, 2014) e Forecast (Hyndman, 2017). A função sarima do pacote ASTSA foi utilizado para ajustar os modelos sazonais de ARIMA $(p, d, q) x(P, D, Q)[s]$, para a previsão a função sarima.for do pacote ASTSA foi utilizada. A função nnetar $e$ forecast do pacote Forecast foram usadas, respectivamente, para ajustar o modelo de RNA e para prever. A função nnetar do acote Forecast ajusta um modelo de RNA do tipo $\operatorname{NNAR}(p, P, k)[s]$ que é similar ao ARIMA, em que $k$ é o número neurônios na camada oculta, $p$ é o número de defasagens da variável explicada, $P$ é o número de defasagens cíclicas da variável explicada, $s$ é o ciclo da série. Portanto, o modelo de Redes Neurais Artificiais construído aqui é bastante limitado, visto que não é possível escolher a função de transferência e outros parâmetros, os únicos parâmetros de escolha são as defasagens cíclicas, autorregressivas e o número de neurônios. Para o SSA foi utilizada a função SSA.Rec descrita por Hassani e Ghodsi (2013) e o pacote Rssa. Para o STL foi utilizada a função st/ do pacote STATS.

A Tabela 2 apresenta o resultado do teste de estacionariedade Mann-Kendall, cuja hipótese nula é a estacionariedade, para o conjunto de treinamento e para a série toda de Belo Monte e Sobradinho. Os resultados mostram que, utilizando o nível de significância de 0.05 , para ambas as séries, o conjunto de treinamento manteve a característica estacionariedade apresentada pela série toda. Os testes de 
estacionariedade também foram realizados para cada componente ao qual o modelo ARIMA ajustado (os resultados destes testes podem ser vistos no anexo B).

Tabela 2 - Resultado do teste de estacionariedade para Belo Monte

\begin{tabular}{|c|c|c|}
\hline & Belo Monte $(\boldsymbol{p}$-valor $)$ & Sobradinho $(\boldsymbol{p}$-valor $)$ \\
\hline Toda & 0.42 & $1 \times 10^{-3}$ \\
\hline Treinamento & 0.64 & $1 \times 10^{-3}$ \\
\hline
\end{tabular}

\subsection{1.}

\section{Modelos propostos para Belo Monte}

A Tabela 3 mostra os modelos ajustados para série de Belo monte utilizando as técnicas descritas no capítulo 3. Como é possível observar os componentes da decomposição SSA permanecem os mesmos, tanto para os modelos ARIMA quanto para os RNA, exceto para o modelo híbrido de RNA-SSA com janela igual a 12. A normalização aplicada nos modelos RNA faz com que a série de autovalores seja mais achatada que quando utilizamos a transformação de Box Cox nos modelos ARIMA. Com isso, mais componentes com comportamento diferenciado são utilizados para chegar aos $95 \%$ de representatividade. Portanto, para a os modelos ARIMA com $\mathrm{L}=12$ só temos duas séries reconstruídas,

Tabela 3 - Modelos ajustados para série de Belo Monte

\begin{tabular}{|c|c|c|c|}
\hline $\begin{array}{c}\text { Modelo/ } \\
\text { Técnica }\end{array}$ & Componente & ARIMA $(\boldsymbol{p}, \boldsymbol{d}, \boldsymbol{q}) \boldsymbol{x}(\boldsymbol{P}, \boldsymbol{D}, \boldsymbol{Q})[\boldsymbol{s}]$ & RNA $(\boldsymbol{p}, \boldsymbol{P}, \boldsymbol{k})$ \\
\hline Puro & & $(1,0,1) \times(1,0,1)[12]$ & $(2,3,6)$ \\
\hline \multirow{2}{*}{ STL } & Tendência & $(2,0,6)$ & $(3,3,6)$ \\
\cline { 2 - 4 } & Resíduos & $(2,0,0) \times(1,0,0)[12]$ & $(1,3,3)$ \\
\hline \multirow{2}{*}{ SSA (L=2) } & RC1 & $(1,0,3) \times(1,0,1)[12]$ & $(3,3,6)$ \\
\cline { 2 - 4 } & RC2 & $(3,0,3) \times(1,0,1)[12]$ & $(6,1,3)$ \\
\hline \multirow{3}{*}{ SSA (L=3) } & RC1 & $(6,0,2) \times(4,0,1)[12]$ & $(2,3,3)$ \\
\cline { 2 - 4 } & RC2 & $(2,0,3) \times(1,1,1)[12]$ & $(6,6,2)$ \\
\cline { 2 - 4 } & RC3 & $(4,0,3) \times(2,1,2)[12]$ & $(3,0,2)$ \\
\hline \multirow{3}{*}{ SSA (L=12) } & REC1 & $(3,0,3) \times(1,0,1)[12]$ & $(2,1,2)$ \\
\cline { 2 - 4 } & REC2 & $(4,0,2) \times(1,1,2)[12]$ & $(3,2,1)$ \\
\hline
\end{tabular}


Como dito no capítulo 3, os resíduos dos modelos ARIMA devem atender as condições de normalidade, homocedasticidade e independência. A Tabela 4 mostra que, a um nível de significância de 5\%, os resíduos dos modelos ajustados são estatisticamente independentes e homocedásticos, porém não normais. O teste Ljung-Box foi realizado considerando o número de defasagens igual a 20, conforme recomendado por (BOX, et al., 2008).

Tabela 4 - Testes de Aderência dos resíduos dos modelos ARIMA da série de Belo Monte

\begin{tabular}{|c|c|c|c|r|r|}
\hline \multirow{2}{*}{ Modelo } & \multirow{2}{*}{ Componentes } & \multicolumn{2}{|c|}{ Normalidade } & Independência & Homocedasticidade \\
\cline { 3 - 6 } & & $\begin{array}{c}\text { Jarque } \\
\text { Bera }\end{array}$ & $\begin{array}{c}\text { Shapiro- } \\
\text { Wilk }\end{array}$ & Ljung-Box & Levene \\
\hline \multirow{2}{*}{ Puro } & & $1 \times 10^{-3}$ & $1 \times 10^{-3}$ & 0.86 & 0.44 \\
\hline \multirow{2}{*}{ STL } & Tendência & $1 \times 10^{-3}$ & $1 \times 10^{-3}$ & 0.11 & 0.47 \\
\cline { 2 - 6 } & Resíduos & $1 \times 10^{-3}$ & $1 \times 10^{-3}$ & 0.99 & 0.14 \\
\hline \multirow{3}{*}{ SSA (L=2) } & REC1 & $1 \times 10^{-3}$ & $1 \times 10^{-3}$ & 0.68 & 0.24 \\
\cline { 2 - 6 } & REC2 & $1 \times 10^{-3}$ & $1 \times 10^{-3}$ & 0.88 & 0.27 \\
\hline \multirow{3}{*}{ SSA (L=3) } & REC1 & $1 \times 10^{-3}$ & $1 \times 10^{-3}$ & 0.98 & 0.47 \\
\cline { 2 - 6 } & REC2 & $1 \times 10^{-3}$ & $1 \times 10^{-3}$ & 0.90 & 0.18 \\
\cline { 2 - 6 } & REC3 & $1 \times 10^{-3}$ & $1 \times 10^{-3}$ & 0.35 & 0.59 \\
\hline \multirow{2}{*}{ SSA (L=12) } & REC1 & $1 \times 10^{-3}$ & $1 \times 10^{-3}$ & 0.83 & 0.43 \\
\cline { 2 - 6 } & REC2 & $1 \times 10^{-3}$ & $1 \times 10^{-3}$ & 0.67 & 0.99 \\
\end{tabular}

$\mathrm{Na}$ etapa 2 (Decomposição e Reconstrução), conforme explicado no capítulo 3, os modelos ARIMA-SSA e RNA-SSA com janela igual a 12 foram construídos utilizando os componentes que representassem pelo menos $95 \%$ do comportamento da série, ou seja, os componentes principais.

A Figura 6 mostra o log dos autovalores da decomposição SSA com janela igual a 12 da série de Belo monte do modelo ARIMA. A proximidade dos autovalores 2 e 3 indica que eles estão associados com a componente sazonal da série. Além disso, após o quarto autovalor, visualiza-se um decaimento lento e contínuo que caracteriza o início do ruído. 


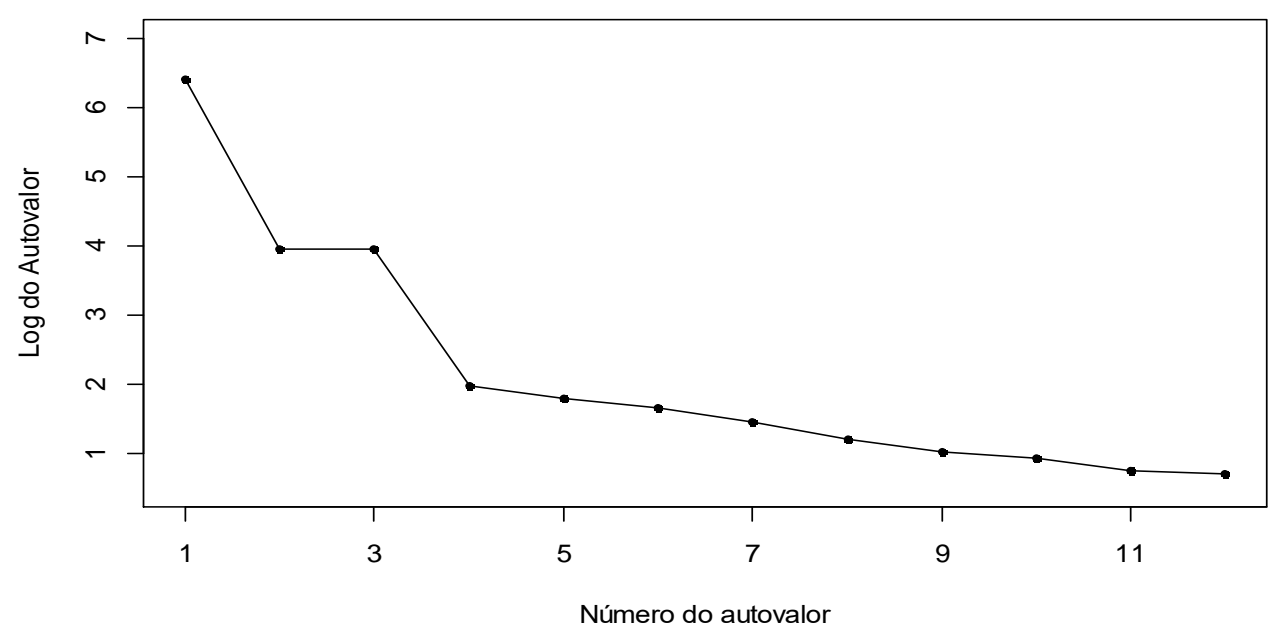

Figura 6 - Autovalores da decomposição SSA com L=12 do modelo ARIMA de Belo Monte

Na Figura 7a observa-se que o primeiro autovetor captura a tendência da série, enquanto os autovetores 2 e 3 apresentam perfis que sugerem sazonalidade. Verifica-se também que os três primeiros componentes explicam 95.24\% da variação total da série temporal.

Os gráficos ilustrados na Figura $7 \mathrm{~b}$ são utilizados na identificação dos períodos das componentes harmônicas da série temporal. Neste caso, é possível identificar formas geométricas nos pares de autovetores (2-3). Tal observação sugere que os autovetores 2 e 3 constituem componentes harmônicas. Por outro lado, a partir do par (3-4), os gráficos resultantes dos cruzamentos dos autovetores apresentam formas sem nenhuma possibilidade de identificação, uma observação que ratifica a ideia do ruído iniciar-se a partir da quarta componente. 


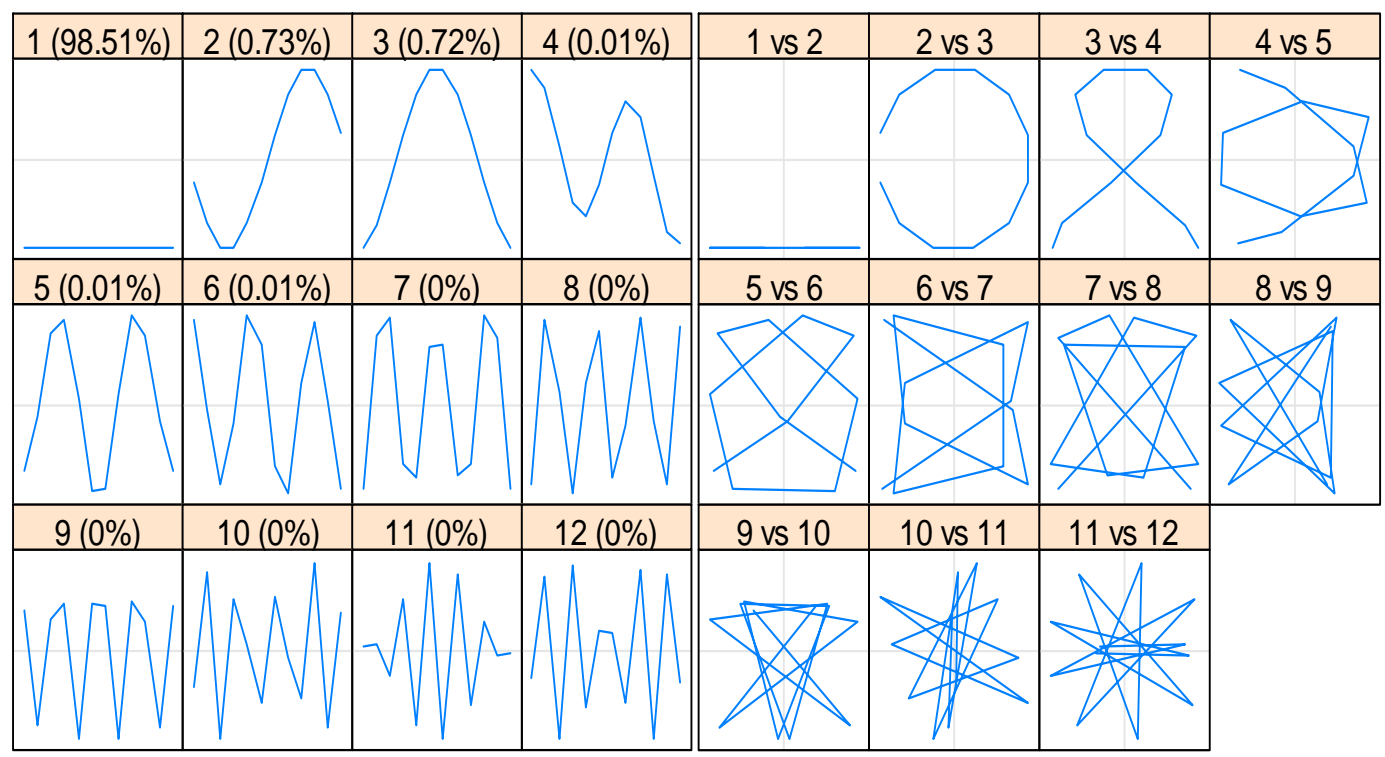

(a) autovetores

(b) Pares de autovetores

Figura 7 - Autovetores modelo ARIMA - SSA ( $\mathrm{L}=12)$ de Belo Monte

Na Figura 8a tem-se a representação gráfica da matriz de correlações ponderadas, na qual se pode verificar que a primeira componente não possui correlação com nenhuma outra componente. Observa-se também, que as autotriplas 2 e 3 são altamente correlacionadas, o que ratifica a interpretação anterior sobre a componente sazonal. A Figura 8b confirma a componente sazonal.

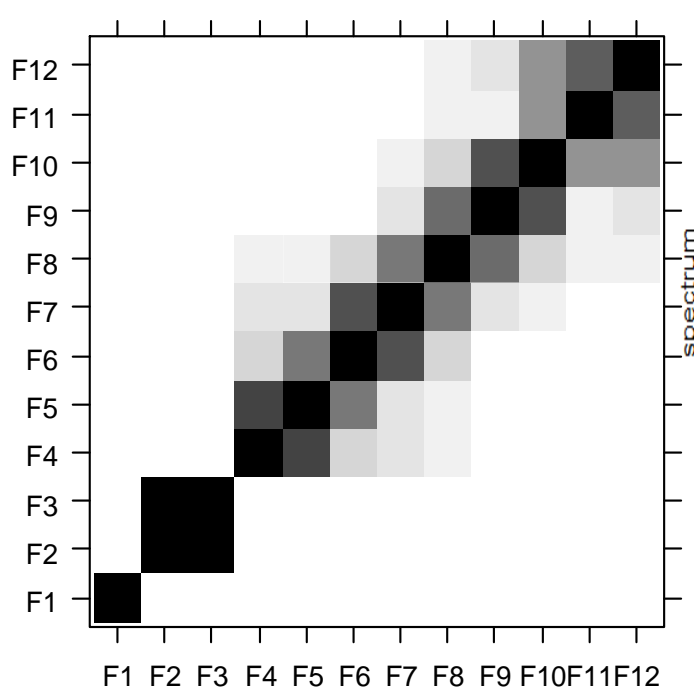

(a) Matriz W- correlação entre os componentes

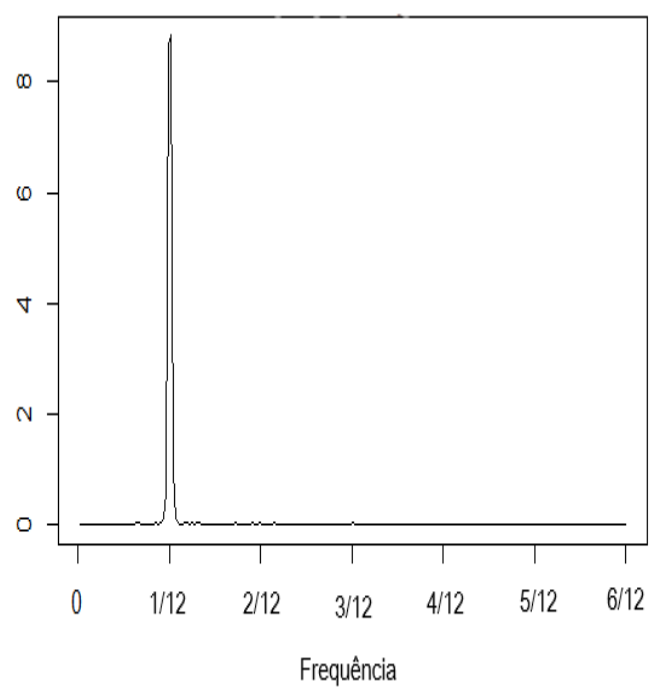

(b) Periodograma dos componentes

Figura 8 - Matriz W-correlação e Periodograma ARIMA- SSA (L=12) de Belo Monte 
Conforme destacado nos parágrafos anteriores os componentes 2 e 3 exibem o mesmo comportamento, portanto para a modelagem seria razoável somar estas séries em uma única série reconstruída, tal como feito por Zhang et al. (2011). De acordo com a Tabela 5, a correlação entre as séries reconstruídas é próxima a zero, isto confirma que reconstrução dos três primeiros componentes em dois é razoável.

Tabela 5 - Matriz de Correlação entre as séries reconstruídas a partir dos componentes principais para o modelo ARIMA-SSA ( $\mathrm{L}=12)$ de Belo Monte

\begin{tabular}{|l|r|r|}
\hline & \multicolumn{1}{|c|}{ REC1 } & \multicolumn{1}{c|}{ REC2 } \\
\hline REC1 & 1.00 & 0.02 \\
\hline REC2 & 0.02 & 1.00 \\
\hline
\end{tabular}

A Figura 9 mostra as séries reconstruídas, isto é, as séries para as quais os modelos ARIMA-SSA de janela 12 foram ajustados.
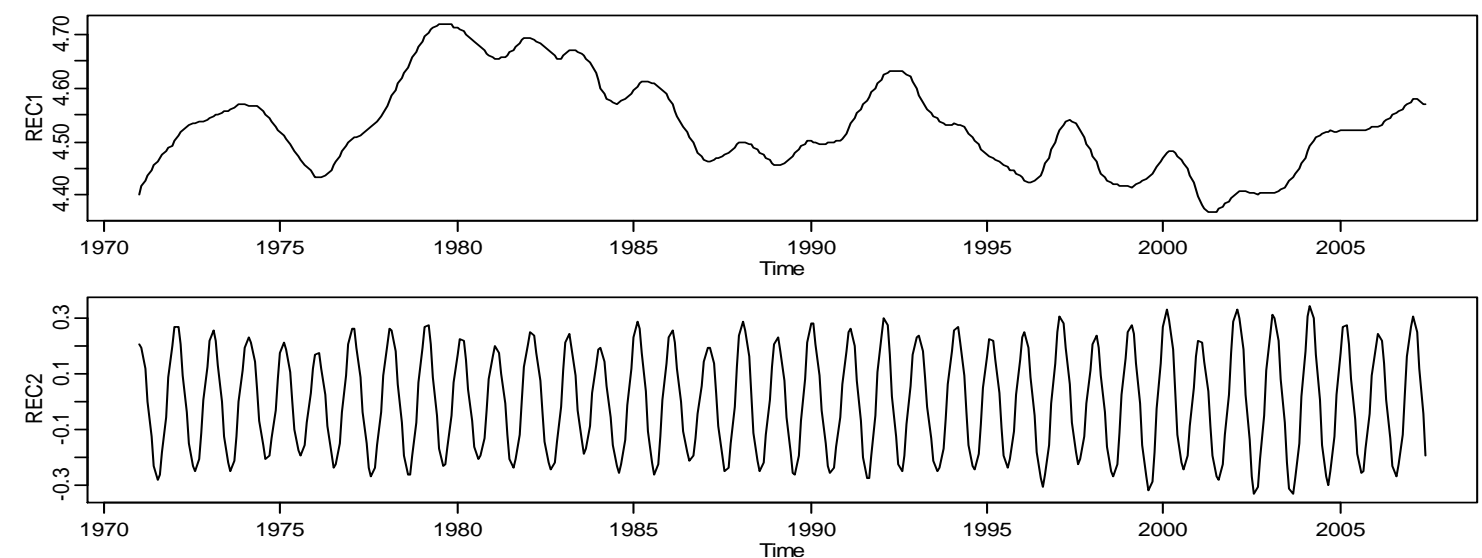

Figura 9 - Séries reconstruídas a partir dos componentes da decomposição de SSA $(\mathrm{L}=12)$ para o modelo ARIMA-SSA de Belo Monte

A Figura 10 mostra o log dos autovalores da decomposição SSA com janela igual a 12 da série de Belo monte do modelo RNA. A proximidade dos autovalores mostra três possíveis harmônicos, os componentes 2 e 3,4 e 5, e 11 e 12 . 


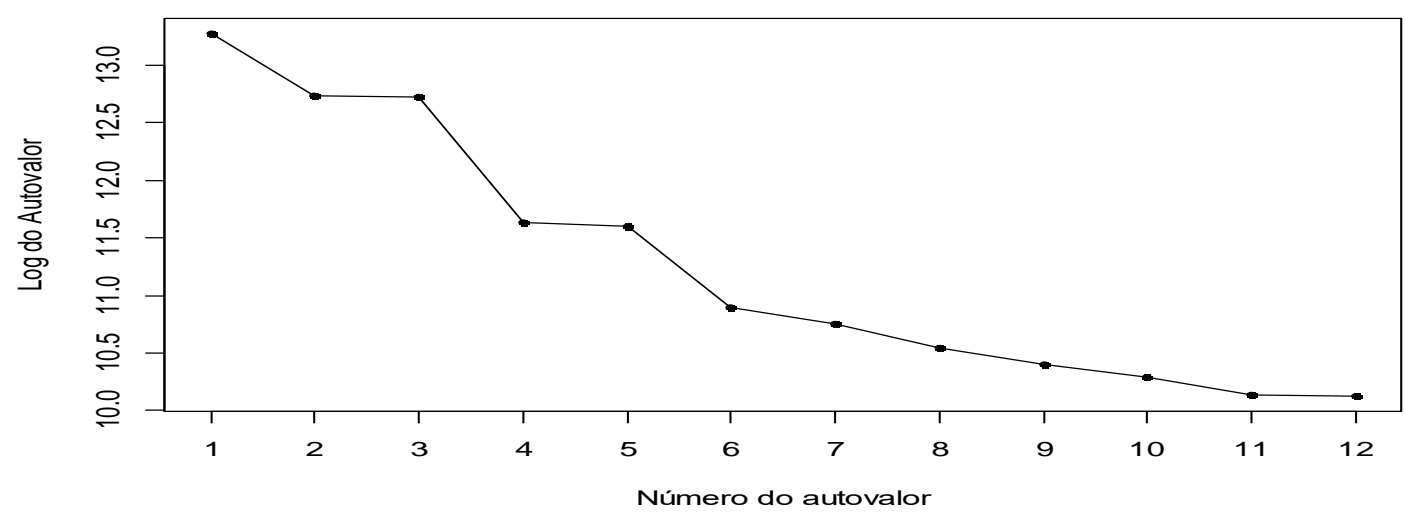

Figura 10 - Autovalores da decomposição SSA $(\mathrm{L}=12)$ para o modelo RNA de Belo Monte

Na Figura 11a observa-se que o primeiro autovetor captura a tendência da série, enquanto os autovetores 2 e 3 apresentam perfis que sugerem sazonalidade, os componentes 4 e 5 mostram algum ciclo. Os gráficos ilustrados na Figura 10b são utilizados na identificação dos períodos das componentes harmônicas da série temporal. Neste caso, é possível identificar formas geométricas nos pares de autovetores (2-3) e (4-5), o par (11-12) mostra-se como ruído. Com isso, observamos que os autovetores 2 e 3, 4 e 5 constituem componentes harmônicas. Por outro lado, a partir do par (5-6), os gráficos resultantes dos cruzamentos dos autovetores apresentam formas sem nenhuma possibilidade de identificação, uma observação que ratifica a ideia do ruído iniciar-se a partir da quinta componente.

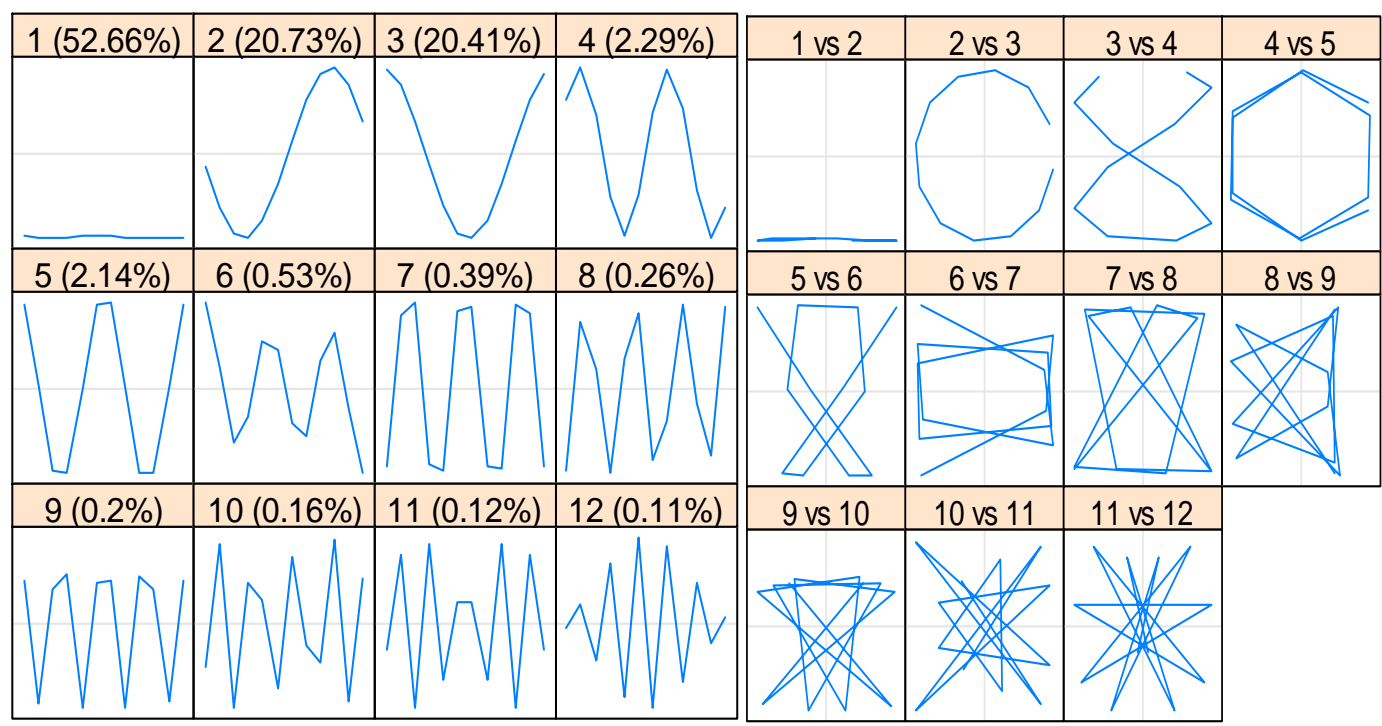

(a) autovetores

(b) Pares de autovetores

Figura 11 - Autovetores modelo RNA-SSA (L=12) de Belo Monte 
$\mathrm{Na}$ Figura 12a tem-se a representação gráfica da matriz de correlações ponderadas, na qual se pode verificar que a primeira componente não possui correlação com nenhuma outra componente. Observa-se também, que as autotriplas 2 e 3 são altamente correlacionadas, assim como as autotriplas 4 e 5 . A Figura 12b confirma a componente sazonal o que ratifica a identificação do componente sazonal (harmônico 2-3) e do ciclo de 6 meses (harmônico 4-5).

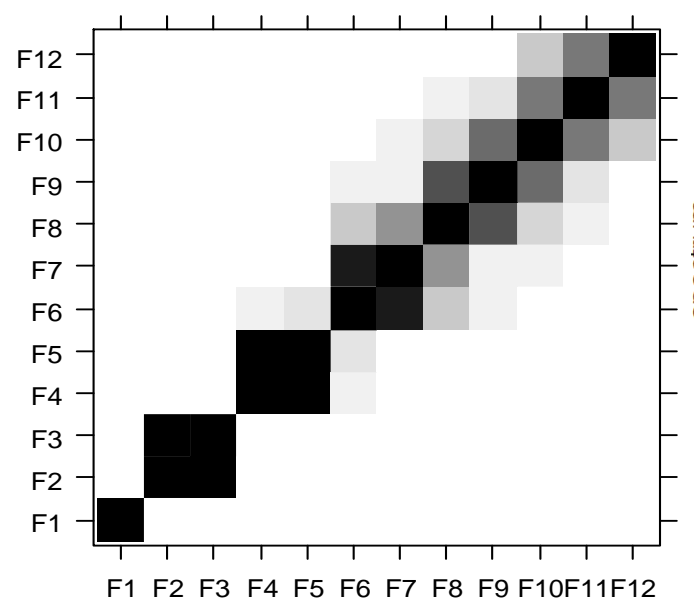

(a) Matriz W- correlação entre os componentes

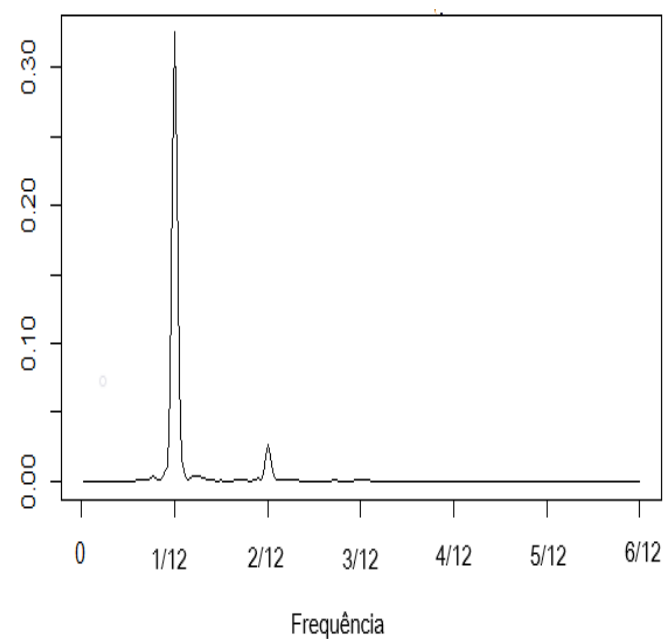

(b) Periodograma dos componentes

Figura 12 - Matriz W-correlação e Periodograma RNA- SSA (L=12) de Belo Monte

A tabela 6 apresenta correlação entre as séries reconstruídas utilizadas para construir o modelo RNA-SSA ( $\mathrm{L}=12)$ da série de Belo Monte. A correlação entre as séries reconstruídas é próxima a zero, isto confirma que reconstrução realizada a partir dos componentes é razoável.

Tabela 6. Matriz de Correlação entre as séries reconstruídas a partir dos componentes principais para o modelo RNA-SSA $(\mathrm{L}=12)$ de Belo Monte

\begin{tabular}{|c|c|c|c|}
\hline & REC1 & REC2 & REC3 \\
\hline REC1 & 1.00 & 0.02 & 0.02 \\
\hline REC2 & 0.02 & 1.00 & 0.003 \\
\hline REC3 & 0.02 & 0.003 & 1.00 \\
\hline
\end{tabular}


A Figura 13 mostra as três séries reconstruídas, isto é, as séries para as quais os modelos RNA-SSA ( $\mathrm{L}=12)$ foram ajustados. A série REC1 mostra a tendência, as séries restantes apresentam os ciclos que compõem a série de Belo Monte.
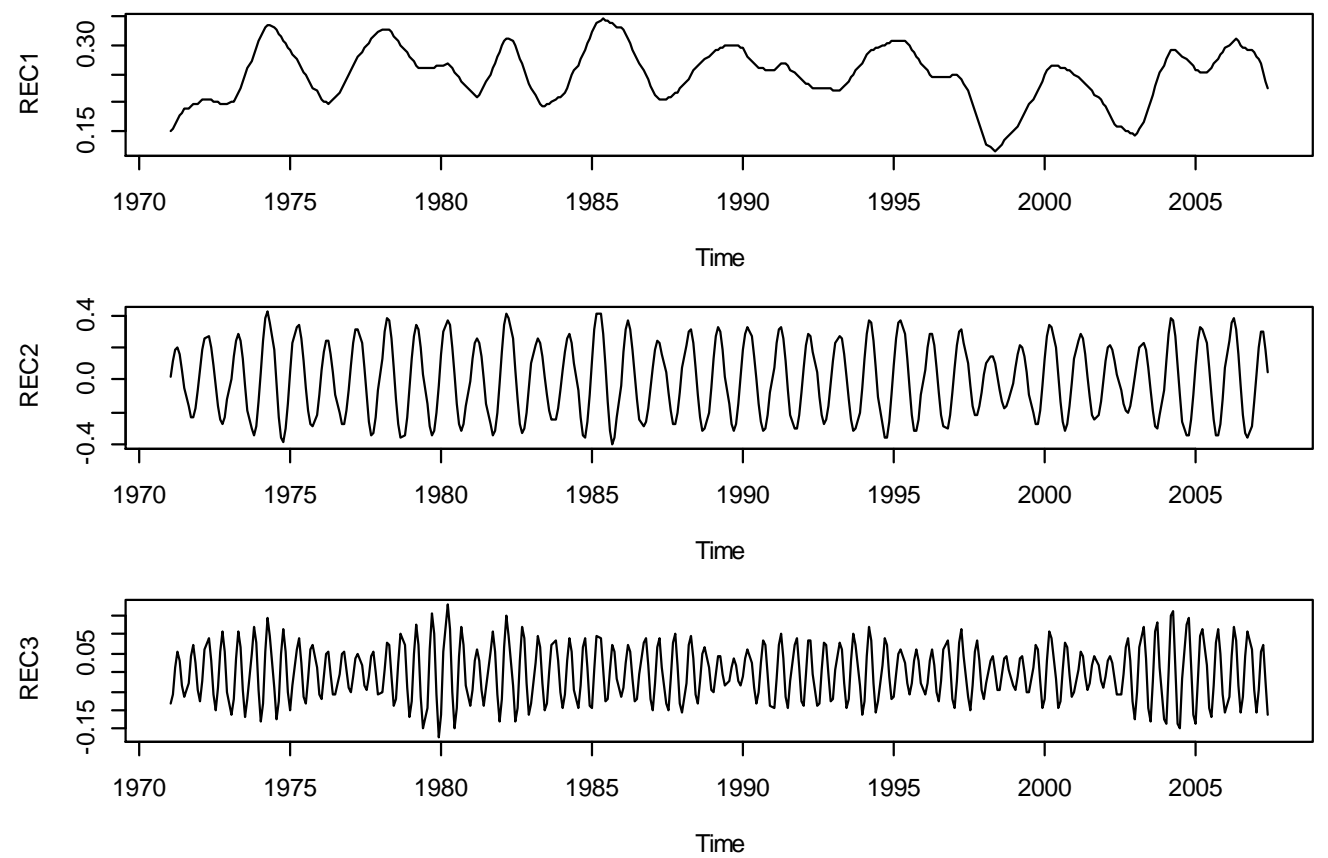

Figura 13 - Séries reconstruídas a partir dos componentes principais da decomposição de SSA para o modelo RNA-SSA de Belo Monte

\subsection{2.}

\section{Modelos propostos para Sobradinho}

A Tabela 7 apresenta os modelos ajustados para série de Sobradinho utilizando as técnicas descritas no capítulo 3. A tabela mostra que os componentes da decomposição SSA permanecem os mesmos para as janelas de tamanho dois e três, tanto para o modelo ARIMA quanto para RNA. Entretanto, para a janela igual a 12, o modelo ARIMA foi ajustado para duas séries reconstruídas, já no modelo RNA foram utilizadas cinco séries reconstruídas. Essa diferença ocorre pelo fato de no modelo ARIMA usar a transformação de Box Cox e o modelo RNA utilizar a normalização dos dados. 
Tabela 7 - Modelos ajustados para a série de Sobradinho

\begin{tabular}{|c|c|c|c|}
\hline Modelo/ Técnica & Componente & ARIMA $(\boldsymbol{p}, \boldsymbol{d}, \boldsymbol{q}) \boldsymbol{x}(\boldsymbol{P}, \boldsymbol{D}, \boldsymbol{Q})[\boldsymbol{s}]$ & $\mathbf{R N A}(\boldsymbol{p}, \boldsymbol{P}, \boldsymbol{k})$ \\
\hline Puro & & $(1,1,1) \times(1,0,1)[12]$ & $(6,2,3)$ \\
\hline \multirow{2}{*}{ STL } & Tendência & $(6,1,6)$ & $(6,0,2)$ \\
\cline { 2 - 4 } & Resíduos & $(1,0,1)$ & $(1,0,2)$ \\
\hline \multirow{2}{*}{ SSA (L=2) } & REC1 & $(1,1,3) \times(1,0,1)[12]$ & $(6,1,6)$ \\
\cline { 2 - 4 } & REC2 & $(2,0,2,) \times(1,1,1)[12]$ & $(1,1,10)$ \\
\hline \multirow{2}{*}{ SSA (L=3) } & REC1 & $(1,1,6) \times(1,0,2)[12]$ & $(3,1,3)$ \\
\cline { 2 - 4 } & REC2 & $(4,0,6) \times(1,1,1)[12]$ & $(1,1,2)$ \\
\cline { 2 - 4 } & REC3 & $(0,0,3) \times(2,1,0)[12]$ & $(3,1,2)$ \\
\hline \multirow{2}{*}{ SSA (L=12) } & REC1 & $(2,1,3) \times(2,0,1)[12]$ & $(1,1,3)$ \\
\cline { 2 - 4 } & REC2 & $(11,0,0) \times(0,0,6)[12]$ & $(3,0,1)$ \\
\cline { 2 - 4 } & REC3 & - & \\
\end{tabular}

A Tabela 8 mostra que, a um nível de significância de 0.05 (5\%), os resíduos dos modelos ajustados para a série de Sobradinho apenas rejeitam a hipótese de normalidade, visto que, respectivamente, pelos testes de Ljung-Box e Levene os resíduos são estatisticamente descorrelatados e homocedásticos. O teste Ljung-Box foi realizado considerando o número de defasagens igual a 20, conforme recomendado por (Box et al., 2008).

Tabela 8 - Testes de Aderência para os resíduos dos modelos ARIMA da série de Sobradinho

\begin{tabular}{|c|c|c|c|c|c|}
\hline \multirow{2}{*}{ Modelo } & \multirow{2}{*}{ Componentes } & \multicolumn{2}{|c|}{ Normalidade } & Independência & Homocedasticidade \\
\cline { 3 - 6 } & & $\begin{array}{c}\text { Jarque } \\
\text { Bera }\end{array}$ & $\begin{array}{c}\text { Shapiro- } \\
\text { Wilk }\end{array}$ & Ljung-Box & Levene \\
\hline \multirow{2}{*}{ Puro } & $1 \times 10^{-3}$ & $1 \times 10^{-3}$ & 0.25 & 0.35 \\
\hline \multirow{2}{*}{ STL } & Tendência & $1 \times 10^{-3}$ & $1 \times 10^{-3}$ & 0.53 & 0.47 \\
\cline { 2 - 6 } & Resíduos & $1 \times 10^{-3}$ & $1 \times 10^{-3}$ & 0.13 & 0.37 \\
\hline \multirow{3}{*}{ SSA (L=2) } & REC1 & $1 \times 10^{-3}$ & $1 \times 10^{-3}$ & 0.27 & 0.14 \\
\cline { 2 - 6 } & REC2 & $1 \times 10^{-3}$ & $1 \times 10^{-3}$ & 0.37 & 0.20 \\
\hline \multirow{3}{*}{ SSA (L=3) } & REC1 & $1 \times 10^{-3}$ & $1 \times 10^{-3}$ & 0.19 & 0.22 \\
\cline { 2 - 6 } & REC2 & $1 \times 10^{-3}$ & $1 \times 10^{-3}$ & 0.59 & 0.32 \\
\hline \multirow{2}{*}{ SSA (L=12) } & REC3 & $1 \times 10^{-3}$ & $1 \times 10^{-3}$ & 0.06 & 0.23 \\
\cline { 2 - 6 } & REC1 & $1 \times 10^{-3}$ & $1 \times 10^{-3}$ & 0.92 & 0.43 \\
\hline
\end{tabular}

Assim como na série de Belo Monte, os modelos ARIMA-SSA e RNA-SSA com janela igual a 12 foram construídos utilizando os componentes principais.

A Figura 14 mostra o log dos autovalores da decomposição SSA com janela igual a 12 da série de Sobradinho do modelo ARIMA. A proximidade dos autovalores 2 e 3 indica que eles estão associados com a componente sazonal da 
série. O decaimento lento e contínuo após o quarto autovalor caracteriza o início do ruído.

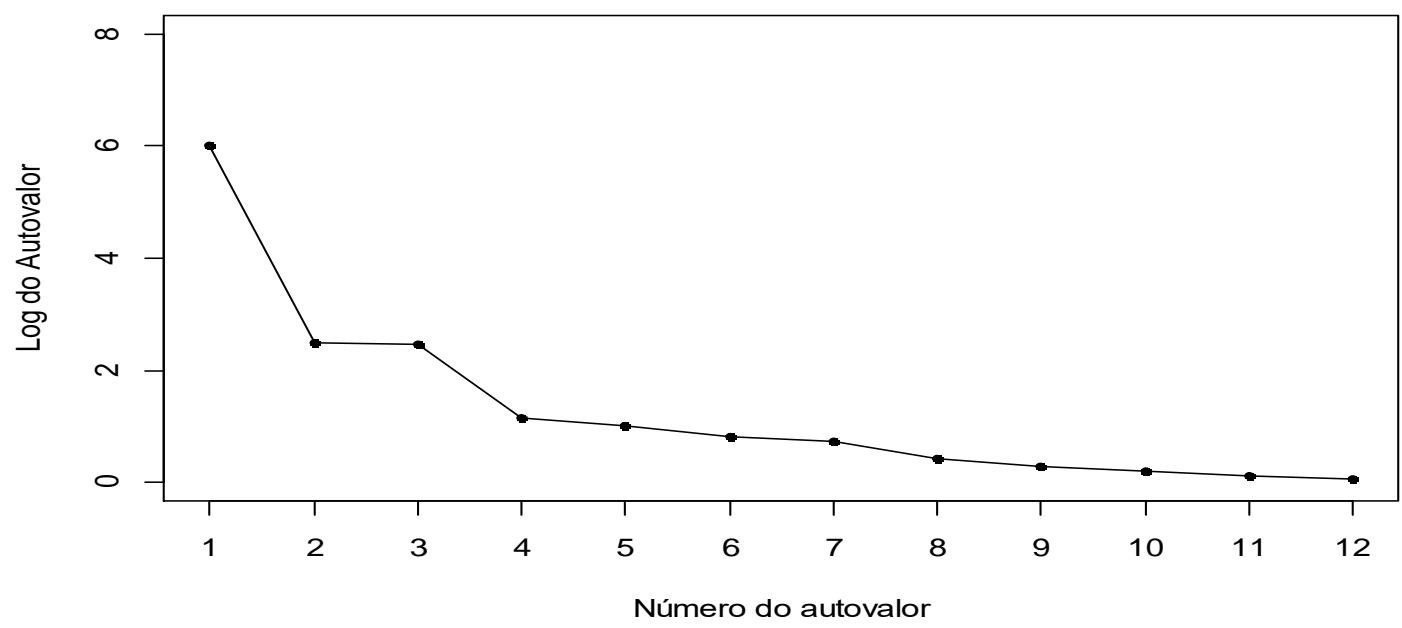

Figura 14 - Autovalores da decomposição SSA com L=12 para o modelo ARIMA-SSA de Sobradinho

A Figura 15a mostra que o primeiro autovetor captura a tendência da série, enquanto os autovetores 2 e 3 apresentam perfis que sugerem sazonalidade. Verifica-se também que os três primeiros componentes explicam mais de $95 \%$ da variação total da série temporal.

Na Figura $15 b$ é possível identificar formas geométricas apenas nos pares de autovetores (2-3). O que sugere que os autovetores 2 e 3 constituem componentes harmônicas e a partir do par (3-4), os gráficos resultantes dos cruzamentos dos autovetores apresentam formas sem nenhuma possibilidade de identificação, uma observação que ratifica a ideia do ruído iniciar-se a partir da quarta componente. 


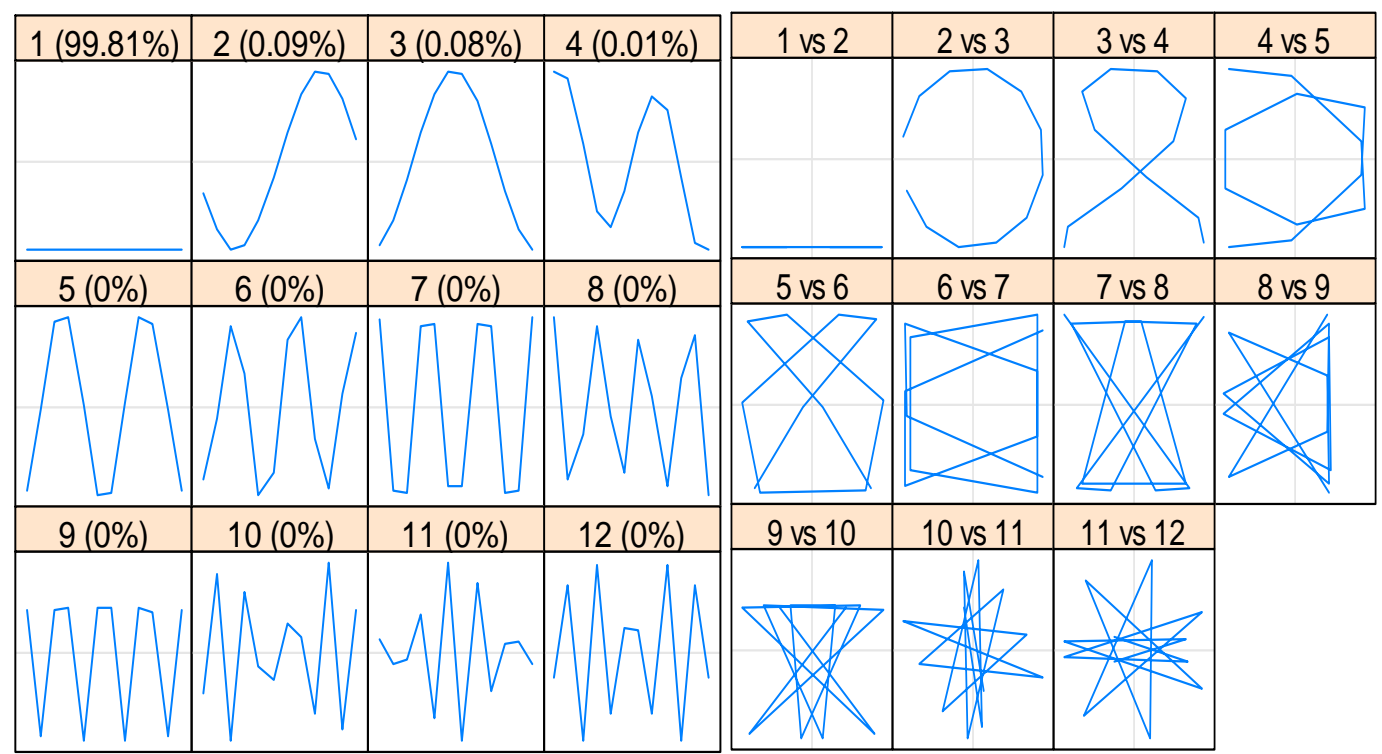

(a) autovetores

(b) Pares de autovetores

Figura 15 - Autovetores modelo ARIMA-SSA $(\mathrm{L}=12)$ de Sobradinho

Na Figura 16a tem-se a representação gráfica da matriz de correlações ponderadas, na qual se pode verificar que a primeira componente não possui correlação com nenhuma outra componente. Observa-se também, que as autotriplas 2 e 3 são altamente correlacionadas, hipótese que é ratificada pela Figura $16 b$.

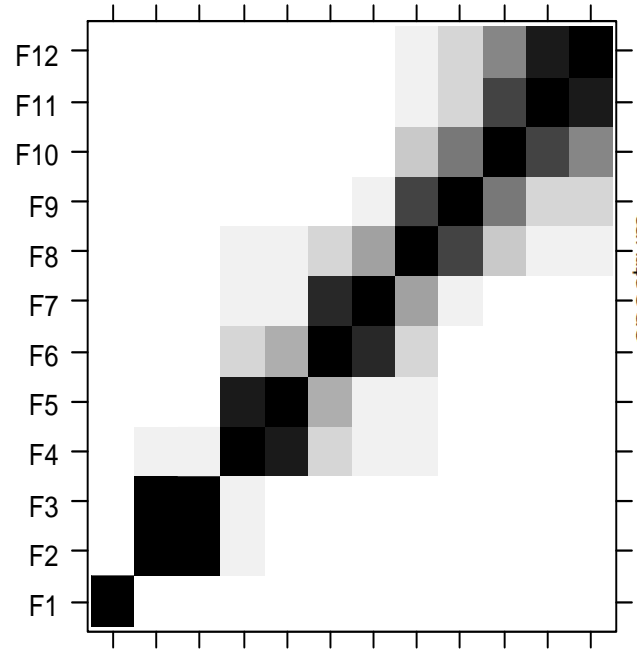

F1 F2 F3 F4 F5 F6 F7 F8 F9 F10F11F12

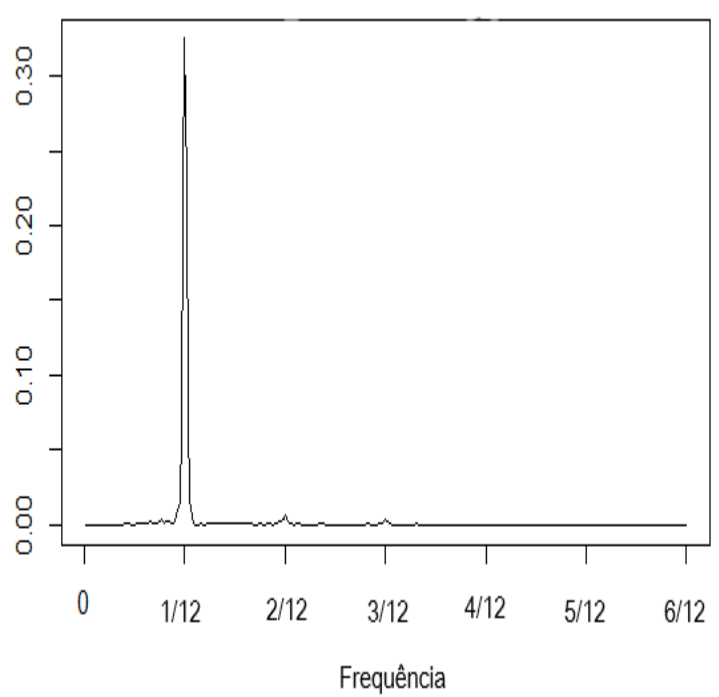
(b) Periodograma dos componentes
(a) Matriz W- correlação entre os componentes

Figura 16 - Matriz W-correlação e Periodograma ARIMA-SSA (L=12) de Sobradinho 
A Tabela 9 apresenta a correlação entre as séries reconstruídas a partir dos componentes de tendência e sazonalidade identificados nos parágrafos anteriores. Os resultados da Tabela 9 mostram que a correlação entre as séries reconstruídas é baixa. A Figura 17 apresenta a série REC1 representa a tendência da série de Sobradinho, já a série REC2 representa o harmônico da sazonalidade.

Tabela 9 - Matriz de Correlação entre as séries reconstruídas a partir dos componentes principais para o modelo ARIMA-SSA ( $\mathrm{L}=12)$ de Sobradinho

\begin{tabular}{|c|r|r|}
\hline & \multicolumn{1}{|c|}{ REC1 } & \multicolumn{1}{c|}{ REC2 } \\
\hline REC1 & 1.00 & 0.03 \\
\hline REC2 & 0.03 & 1.00 \\
\hline
\end{tabular}
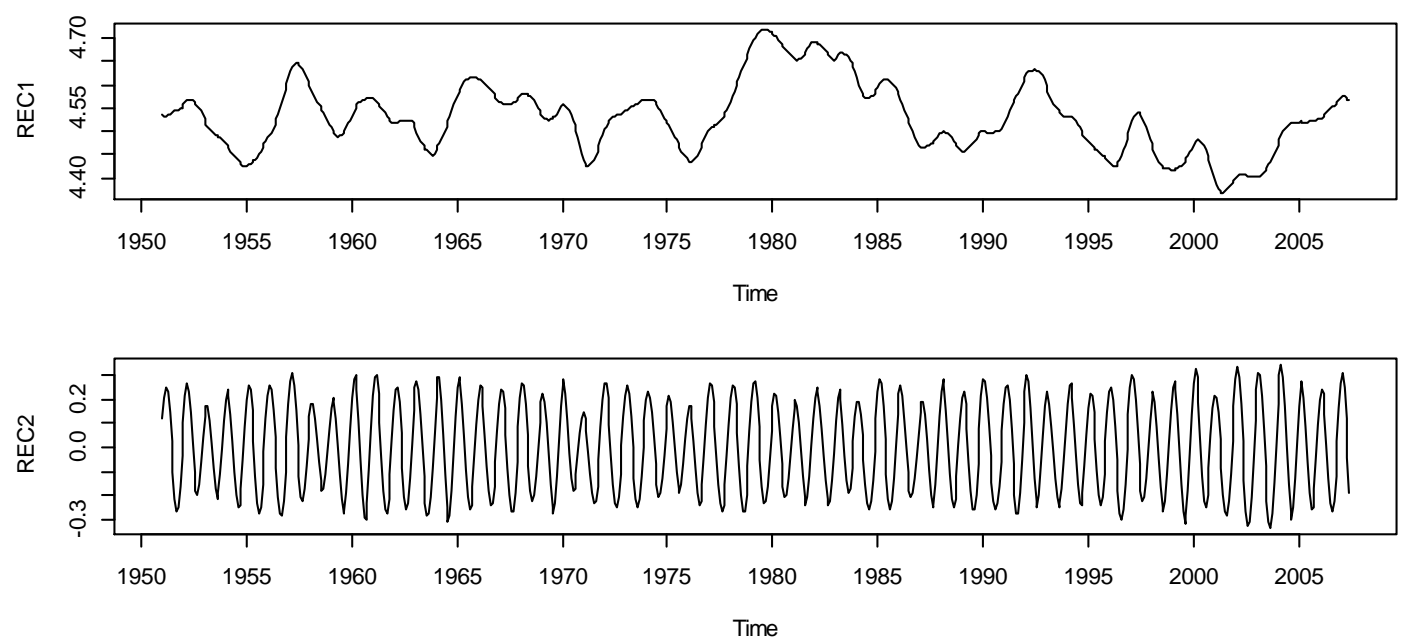

Figura 17 - Séries reconstruídas a partir dos componentes principais para o modelo ARIMA-SSA

$$
\text { ( } \mathrm{L}=12) \text { de Sobradinho }
$$

Como explicado anteriormente nos modelos ARIMA foi aplicado a transformação de Box-Cox, já nos modelos RNA foi aplicada a normalização. Com isso, na decomposição SSA com janela igual doze os componentes principais se modificam.

A Figura 18 mostra o log dos autovalores da decomposição SSA com janela igual a 12 da série de Sobradinho do modelo RNA. A Figura 18 indica três possíveis harmônicos, os pares de componentes 2-3, 4-5 e 11-12. 


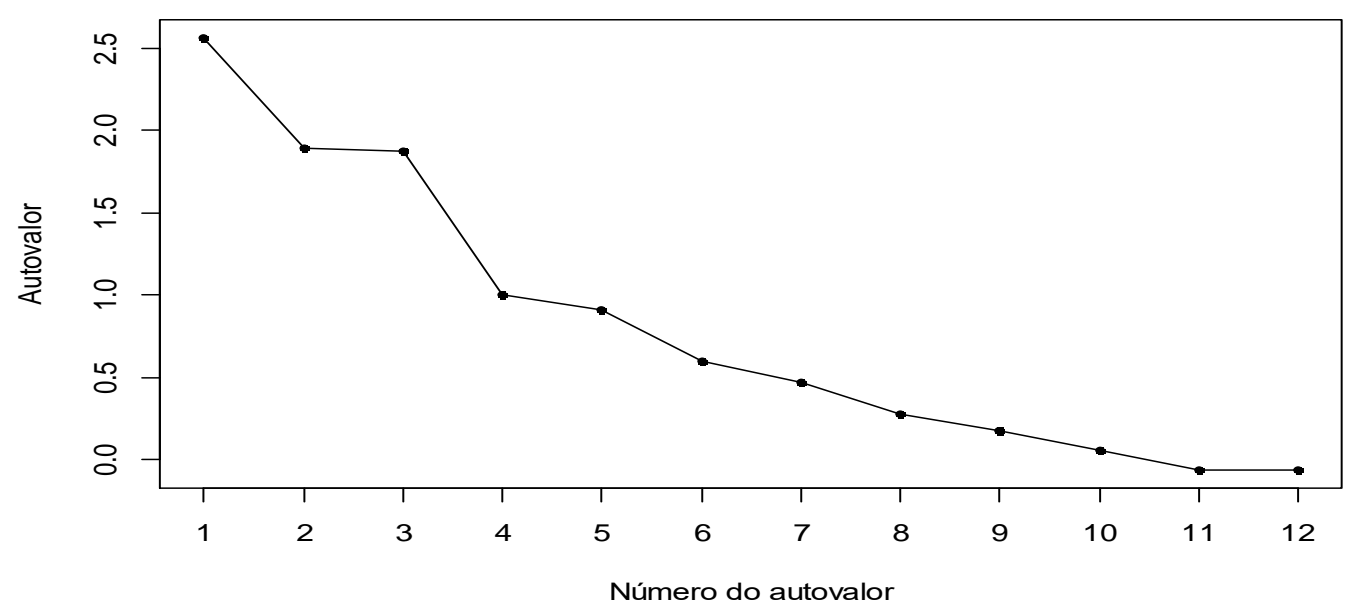

Figura 18 - Autovalores da decomposição SSA com L=12 para o modelo RNA-SSA de Sobradinho

Na Figura 19a observa-se que o primeiro autovetor captura a tendência da série, enquanto os autovetores 2 e 3 apresentam perfis que sugerem sazonalidade, os componentes 4 e 5 mostram algum ciclo. Nos gráficos apresentados na Figura 19 b é possível identificar formas geométricas nos pares de autovetores (2-3) e (45), o par (11-12) mostra-se como ruído. Com isso, observamos que os autovetores 2 e 3, 4 e 5 constituem componentes harmônicas que serão utilizadas para gerar as séries reconstruídas. Os gráficos resultantes dos cruzamentos dos autovetores a partir do par (5-6) apresentam formas sem definição, uma observação que ratifica que o ruído se iniciar a partir da sexta componente.

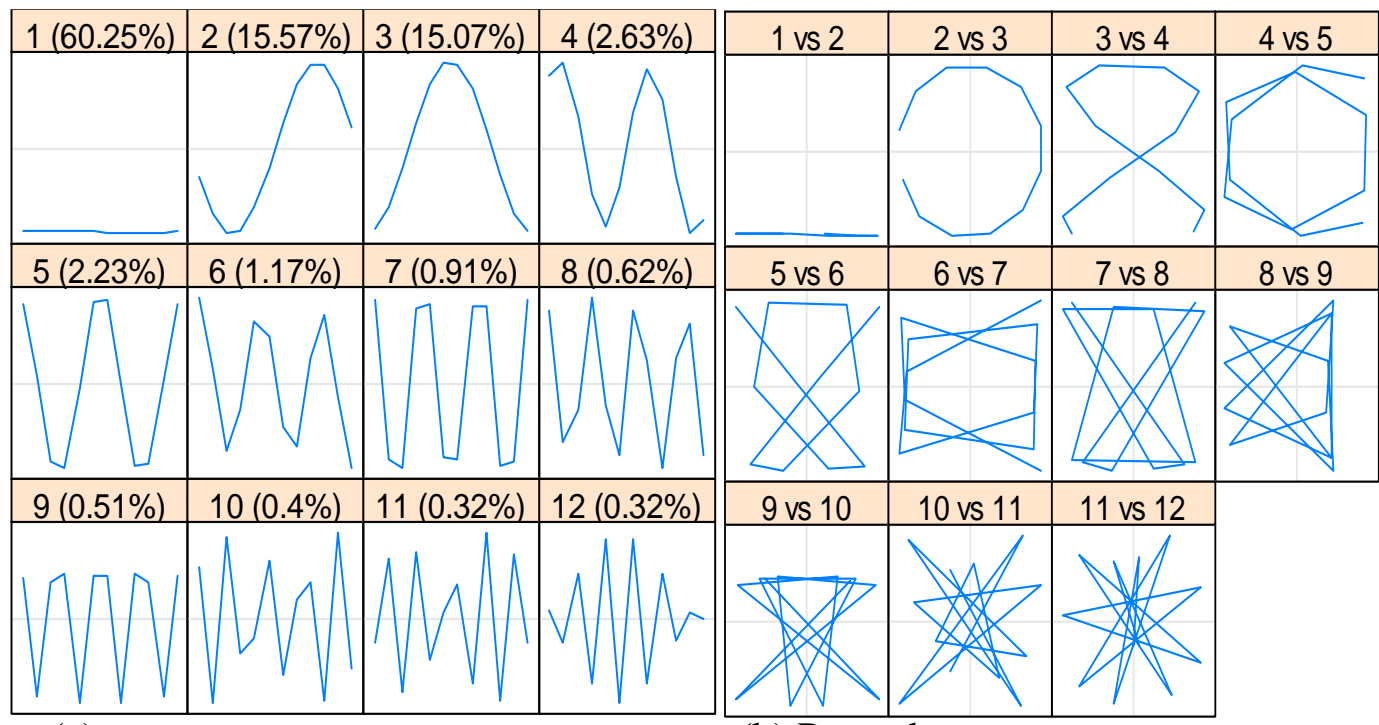

(a) autovetores (b) Pares de autovetores

Figura 19 - Autovetores modelo RNA-SSA (L=12) de Sobradinho 
A Figura 20a mostra que a primeira componente não possui correlação com nenhuma outra componente. Observa-se também, que as autotriplas 2-3, e 4-5 são altamente correlacionadas, o que ratifica a interpretação anterior sobre a componente sazonal. Além disso, Figura 20b confirma a componente sazonal no par de autotriplas 2-3 e a componente cíclica de 6 meses representado pelo par de autotriplas 4-5.

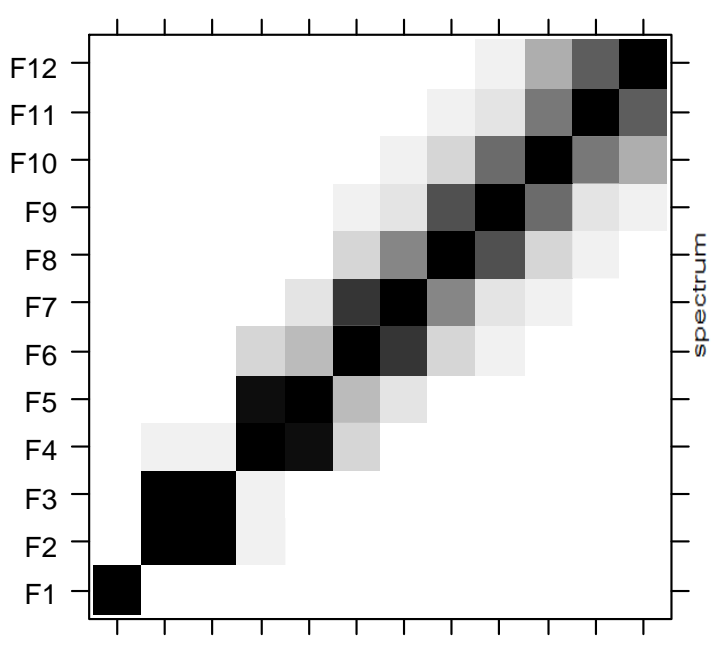

F1 F2 F3 F4 F5 F6 F7 F8 F9 F10F11F12

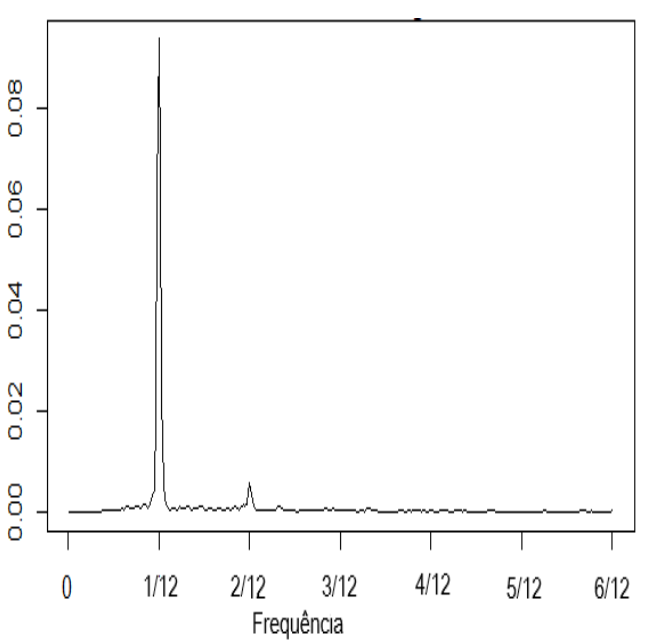

(b) Periodograma dos componentes

Figura 20 - Matriz W-correlação e Periodograma RNA-SSA (L=12) de Sobradinho

A Tabela 10 mostra que as três séries reconstruídas têm baixa correlação entre si, portanto, a reconstrução realizada neste trabalho é razoável. A Figura 21 mostra as séries reconstruídas a partir do par de autovalores 2-3, 4-5 e da tendência. A série REC1 representa a tendência, a série REC2 representa os componentes da sazonalidade e a série REC3 mostra os componentes de 4-5.

Tabela 10 - Matriz de Correlação entre as séries reconstruídas a partir dos componentes principais para o modelo RNA-SSA ( $\mathrm{L}=12)$ de Sobradinho

\begin{tabular}{|c|r|r|r|}
\hline & \multicolumn{1}{|c|}{ REC1 } & \multicolumn{1}{|c|}{ REC2 } & \multicolumn{1}{c|}{ REC3 } \\
\hline REC1 & 1.00 & 0.02 & 0.02 \\
\hline REC2 & 0.02 & 1.00 & 0.02 \\
\hline REC3 & 0.02 & 0.02 & 1.00 \\
\hline
\end{tabular}



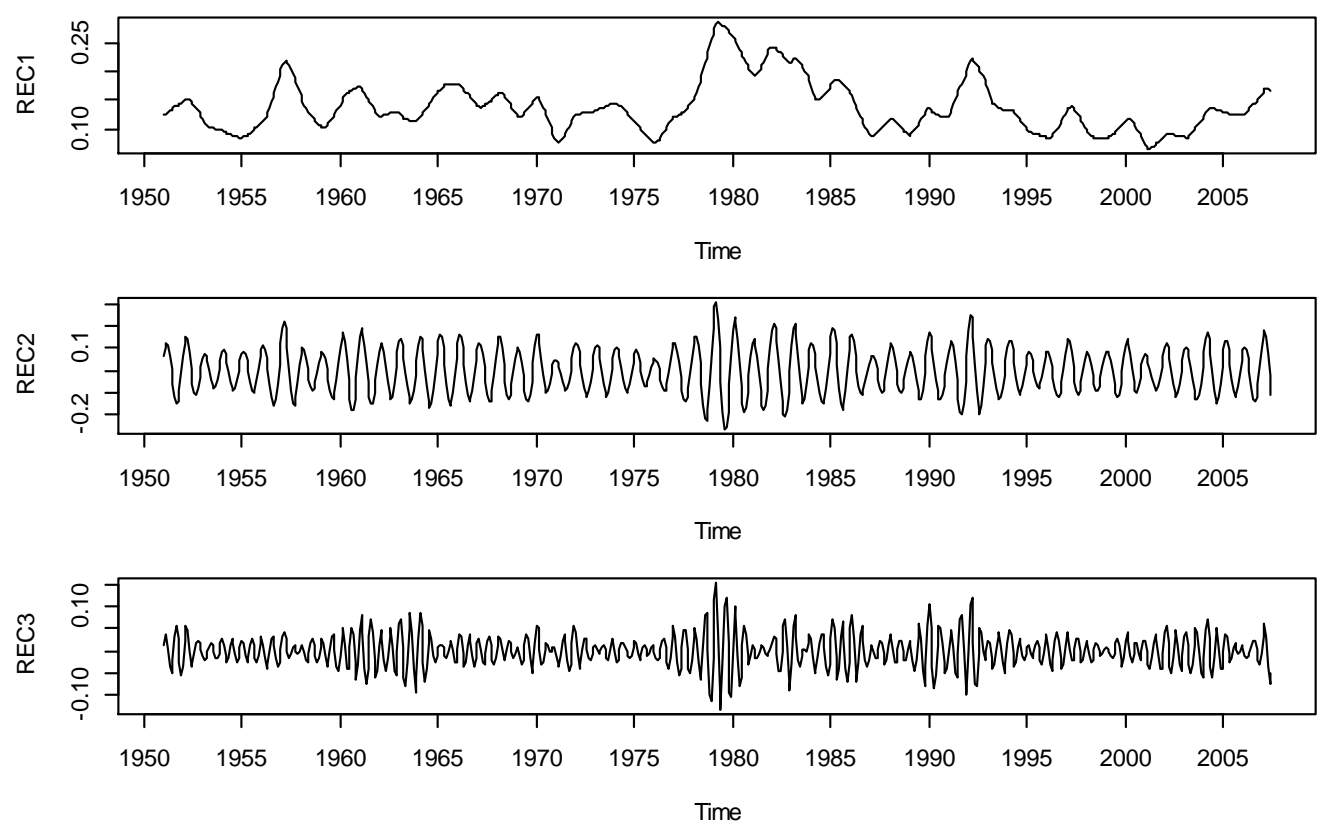

Figura 21 - Séries reconstruídas a partir dos componentes principais para o modelo RNA-SSA ( $\mathrm{L}=12)$ de Sobradinho

\section{2.}

\section{Resultados e discussão dos Modelos propostos}

Nesta seção será apresentada a análise de resultados dos modelos ajustados para as séries de Belo Monte e Sobradinho, em termos das métricas descritas no capítulo 3.

\subsection{1.}

\section{Resultados e discussão dos modelos de Belo Monte}

A Tabela 11 apresenta a comparação de desempenho dos modelos ajustados para as vazões de Belo Monte, em negrito são destacados o melhor modelo para cada métrica. Os resultados mostram que todos os modelos obtiveram um excelente desempenho em termos de NSE e KGE, exceto o modelo ARIMA-STL que obteve um bom desempenho. Portanto os modelos conseguem representar bem o comportamento do período de teste. O modelo ARIMA puro obteve o menor MAPE, porém, o modelo RNA puro obteve o melhor RMSE, KGE e NSE. Sendo assim, concluímos que o modelo RNA puro foi o melhor entre os modelos testados e que, em geral, os modelos puros se mostram superior aos híbridos para as séries analisadas. 
Tabela 11 - Resultado das métricas dos Modelos de Belo Monte para o período de teste

\begin{tabular}{|l|r|r|r|c|}
\hline Modelo & \multicolumn{1}{|c|}{ MAPE } & \multicolumn{1}{c|}{ RMSE } & \multicolumn{1}{c|}{ KGE } & \multicolumn{1}{c|}{ NSE } \\
\hline ARIMA & $\mathbf{0 . 2 1}$ & $2,334.69$ & 0.85 & 0.89 \\
\hline ARIMA-STL & 0.28 & $3,736.41$ & 0.56 & 0.72 \\
\hline ARIMA -SSA (L=2) & 0.30 & $2,558.97$ & 0.83 & 0.87 \\
\hline ARIMA -SSA (L=3) & 0.30 & $2,447.14$ & 0.87 & 0.88 \\
\hline ARIMA -SSA (L=12) & 0.23 & $2,890.72$ & 0.90 & 0.83 \\
\hline RNA & 0.23 & $\mathbf{2 , 2 0 1 . 3 7}$ & $\mathbf{0 . 9 3}$ & $\mathbf{0 . 9 0}$ \\
\hline RNA-STL & 0.29 & $2,370.07$ & 0.88 & 0.89 \\
\hline RNA-SSA (L=2) & 0.31 & $2,614.39$ & 0.89 & 0.86 \\
\hline RNA-SSA (L=3) & 0.31 & $2,485.38$ & 0.82 & 0.88 \\
\hline RNA-SSA (L=12) & 0.28 & $2,366.32$ & 0.92 & 0.89 \\
\hline
\end{tabular}

Na Figura 22 são apresentados os modelos ARIMA ajustados para a série de Belo Monte, para os modelos ARIMA-SSA foi escolhido a janela com melhor resultado. Apesar do conjunto de treinamento conter o range de valores do conjunto de teste, nenhum dos modelos ARIMA foi capaz de capturar todos os períodos de afluência alta, sendo o modelo ARIMA-STL o pior nesse sentido. Entretanto, todos os modelos conseguiram obter um bom desempenho na previsão nos meses de baixa afluência. O modelo ARIMA puro foi o que mais conseguiu se aproximar dos Valores observados nos períodos de alta afluência, isso ajuda a explica o desempenho superior do modelo ARIMA puro com relação aos híbridos.

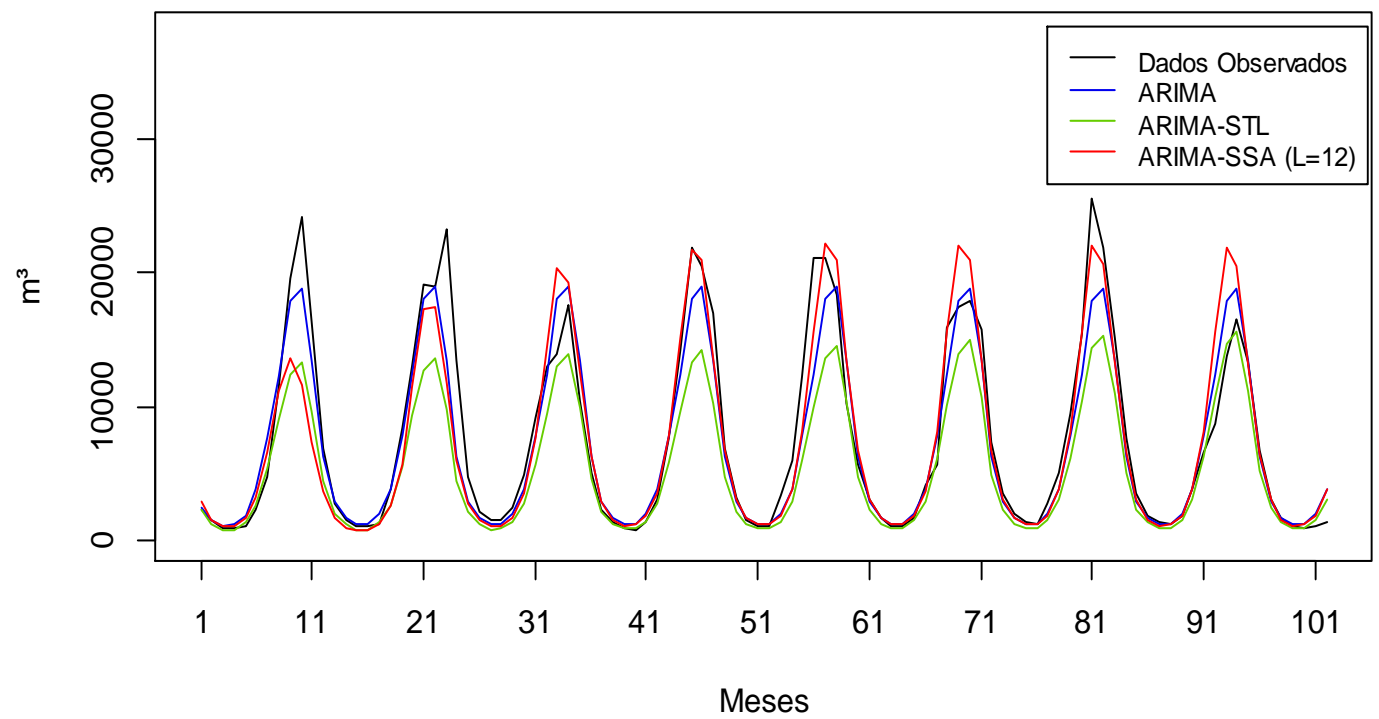

Figura 22 - Comparação de Previsão entre os modelos ARIMA para o conjunto de teste de Belo Monte 
A Figura 23 mostra os modelos de RNA para cada uma das técnicas aplicadas. As previsões de cada modelo mostram que, em geral, diferente dos modelos ARIMA, os modelos RNA conseguem capturar bem as vazões altas. Apesar disso, os modelos RNA em alguns períodos de baixa afluência apresentam valores bem diferentes dos dados observados. Com isso, é possível verificar alguns períodos onde as vazões previstas pelos modelos RNA-STL e RNA-SSA ( $L=12)$ são bem diferentes dos dados observados.

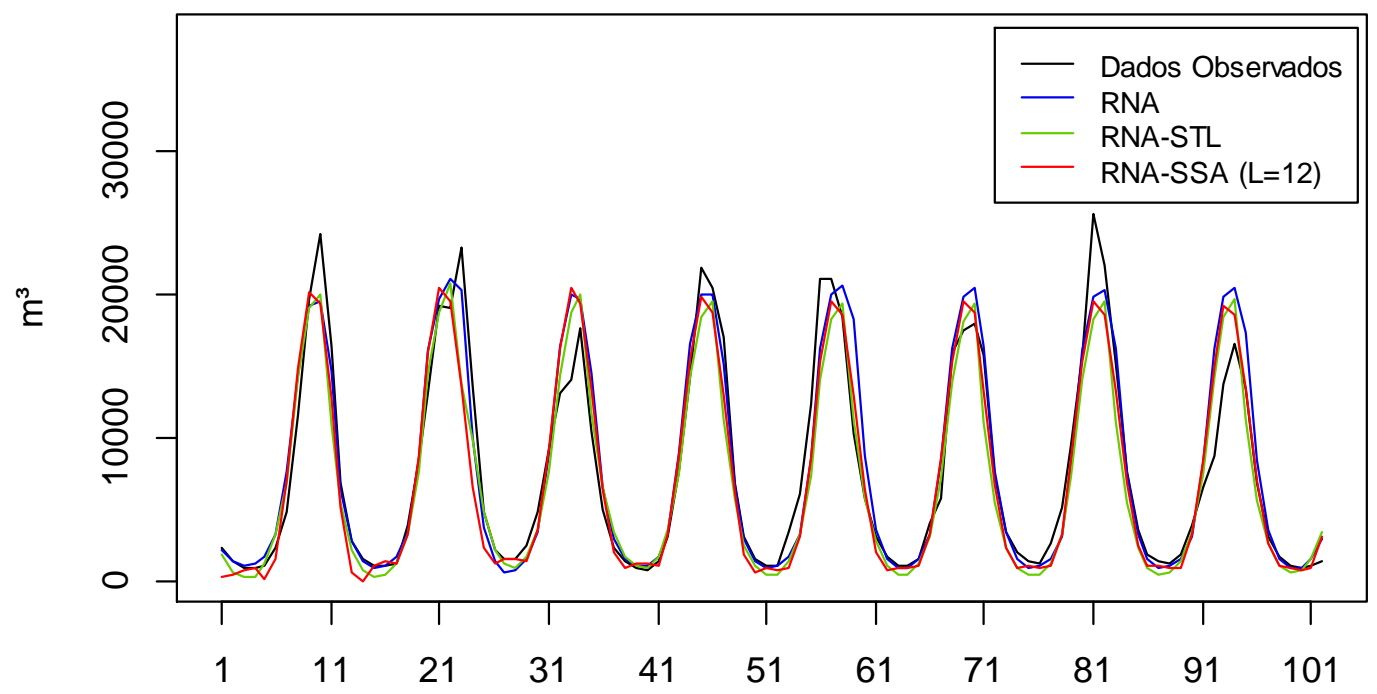

Figura 23 - Comparação de Previsão entre os modelos RNA para o conjunto de teste de Belo Monte

A Figura 24 mostra a comparação gráfica entre o melhor modelo ARIMA e RNA para o conjunto de teste da série de Belo Monte, isto é, os modelos puros de ambas as técnicas. $\mathrm{O}$ modelo RNA apresenta previsões mais altas que o modelo ARIMA para todos períodos de alta afluência, isso ajuda a explicar o melhor desempenho em termos de RMSE e NSE. Ademais, ambos os modelos conseguem prever bem os períodos de baixa afluência para todo o conjunto de teste. 


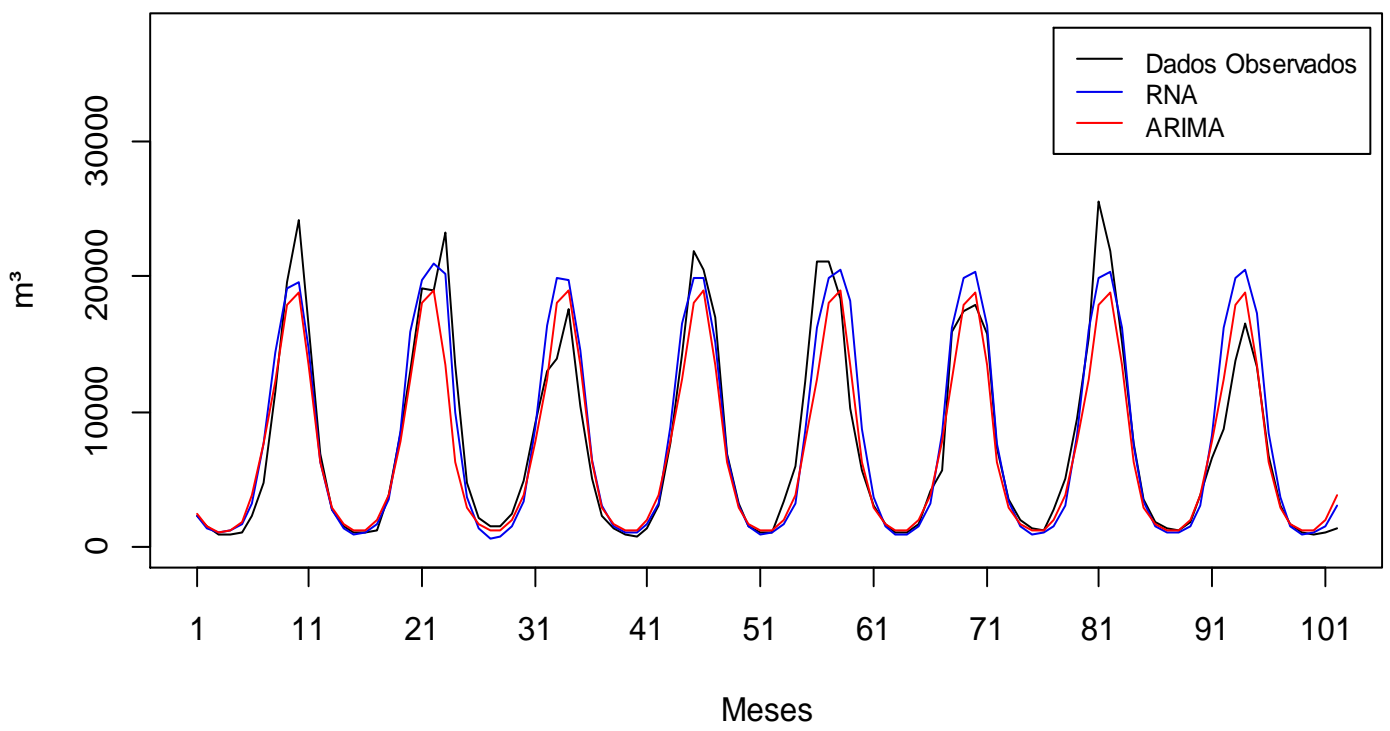

Figura 24 - Comparação entre os modelos de RNA e ARIMA com melhor desempenho para a série de Belo Monte

\subsection{2.}

\section{Resultados dos modelos de Sobradinho}

A tabela 12 apresenta o desempenho comparado dos modelos ajustados para as vazões de Sobradinho, em negrito são destacados o melhor modelo para cada métrica. Os resultados mostram muita discrepância de desempenho entre os modelos testados. Os modelos ARIMA, em geral, apresentam um desempenho pior que os modelos de RNA.

Entre os modelos ARIMA, o modelo ARIMA-STL obteve o pior desempenho. Já para os modelos de RNA o pior é o modelo RNA-SSA (L=12). Os modelos com melhor MAPE são ARIMA-SSA $(\mathrm{L}=3)$ e RNA-SSA $(\mathrm{L}=3)$, mesmo assim estes apresentam um MAPE elevado, 41\%. Em termos de RMSE e KGE o melhor modelo também é o ARIMA-SSA ( $\mathrm{L}=3)$. Analisando o NSE temos que o modelo ARIMA-SSA ( $\mathrm{L}=3)$ e o modelo RNA-SSA $(\mathrm{L}=3)$ apresentam um bom desempenho, mas o RNA-STL tem o melhor NSE entre todos os modelos testados. Portanto, o ARIMA-SSA ( $\mathrm{L}=3)$ é o melhor modelo. Além disso, podemos concluir que para a série de Sobradinho os modelos híbridos, em geral, foram melhores que os híbridos, mesma conclusão de Santos e Silva (2014). 
Tabela 12 - Resultado das métricas dos Modelos de Sobradinho para o período de teste

\begin{tabular}{|l|r|r|r|r|}
\hline Modelos & \multicolumn{1}{|c|}{ MAPE } & \multicolumn{1}{c|}{ RMSE } & \multicolumn{1}{c|}{ KGE } & \multicolumn{1}{c|}{ NSE } \\
\hline ARIMA & 0.57 & 1003.69 & 0.42 & 0.65 \\
\hline ARIMA-STL & 0.85 & 1445.13 & -0.20 & 0.35 \\
\hline ARIMA-SSA $(\mathrm{L}=2)$ & 0.69 & 1196.59 & 0.18 & 0.53 \\
\hline ARIMA-SSA $(\mathbf{L}=\mathbf{3})$ & $\mathbf{0 . 4 1}$ & $\mathbf{8 6 7 . 3 9}$ & $\mathbf{0 . 5 7}$ & 0.68 \\
\hline ARIMA-SSA $(\mathrm{L}=12)$ & 0.69 & 1215.16 & 0.15 & 0.54 \\
\hline RNA & 0.46 & 1037.92 & 0.38 & 0.67 \\
\hline RNA-STL & 0.43 & 973.88 & 0.46 & $\mathbf{0 . 7 3}$ \\
\hline RNA-SSA $(\mathrm{L}=2)$ & 0.46 & 946.02 & 0.49 & 0.71 \\
\hline RNA-SSA $(\mathbf{L}=\mathbf{3})$ & $\mathbf{0 . 4 1}$ & 878.39 & 0.56 & 0.64 \\
\hline RNA-SSA $(\mathrm{L}=12)$ & 0.56 & 1096.44 & 0.31 & 0.65 \\
\hline
\end{tabular}

A Figura 25 mostra o desempenho de previsão dos modelos ARIMA para a série de Sobradinho. A série de dados observados mostra queda de tendência nas últimas 30 observações, nenhum dos modelos ARIMA conseguiu capturar bem essa queda de tendência. O modelo ARIMA-STL prevê vazões muito mais altas que os valores observados. Os modelos ARIMA e ARIMA-SSA $(\mathrm{L}=3)$, que são os que visualmente acompanham melhor a evolução da série original, não conseguem acompanhar tão bem os períodos de vazões baixas. Uma explicação para esse baixo desempenho pode ser a dificuldade de extrapolar os dados para um valor que está fora do conjunto de treinamento.

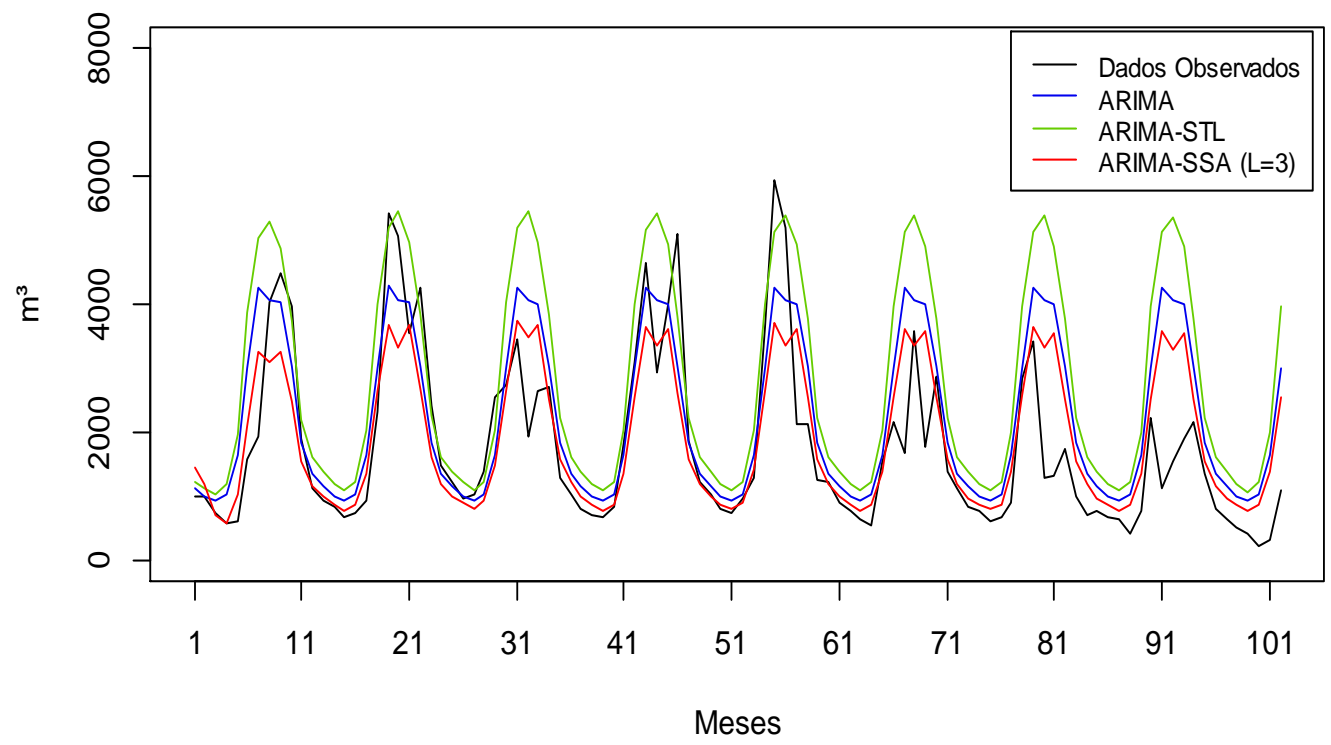

Figura 25 - Comparação de Previsão entre os modelos ARIMA para o conjunto de teste de Sobradinho 
Na Figura 26 apresenta graficamente as previsões dos modelos RNA ajustados para a série de Sobradinho. O modelo RNA-SSA $(\mathrm{L}=3)$ é o único que apresenta queda na tendência ao longo dos meses previstos. A análise gráfica mostra que modelos RNA têm dificuldade de prever bem as primeiras observações do conjunto de teste. Mas para os últimos meses do conjunto de teste os modelos RNA conseguem prever valores mais próximos aos observados do que os modelo ARIMA.

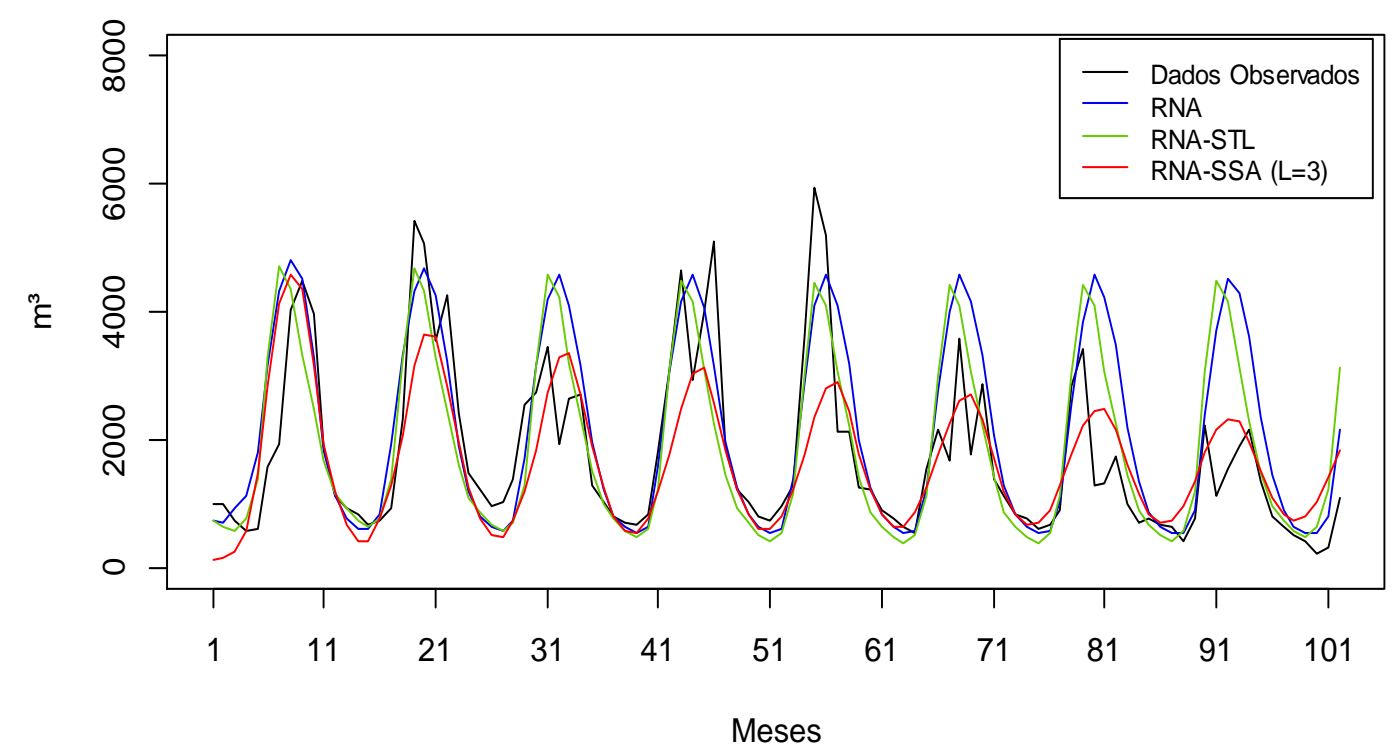

Figura 26 - Comparação de Previsão entre os modelos RNA para o conjunto de teste de Sobradinho

A comparação gráfica entre os melhores modelos de previsão para a série de Sobradinho é apresentada na Figura 27. Esta mostra que o modelo ARIMA-SSA $(\mathrm{L}=3)$ consegue representar melhor as vazões mais baixas durante as sessenta primeiras observações do conjunto de teste da série de Sobradinho. Isso ajuda a explicar o RMSE e NSE melhores que o modelo RNA-SSA (L=3). Ademais, a Figura 27 mostra que mesmo os melhores modelos não conseguem reproduzir bem os valores observados no conjunto de teste, isso explica o MAPE elevado. 


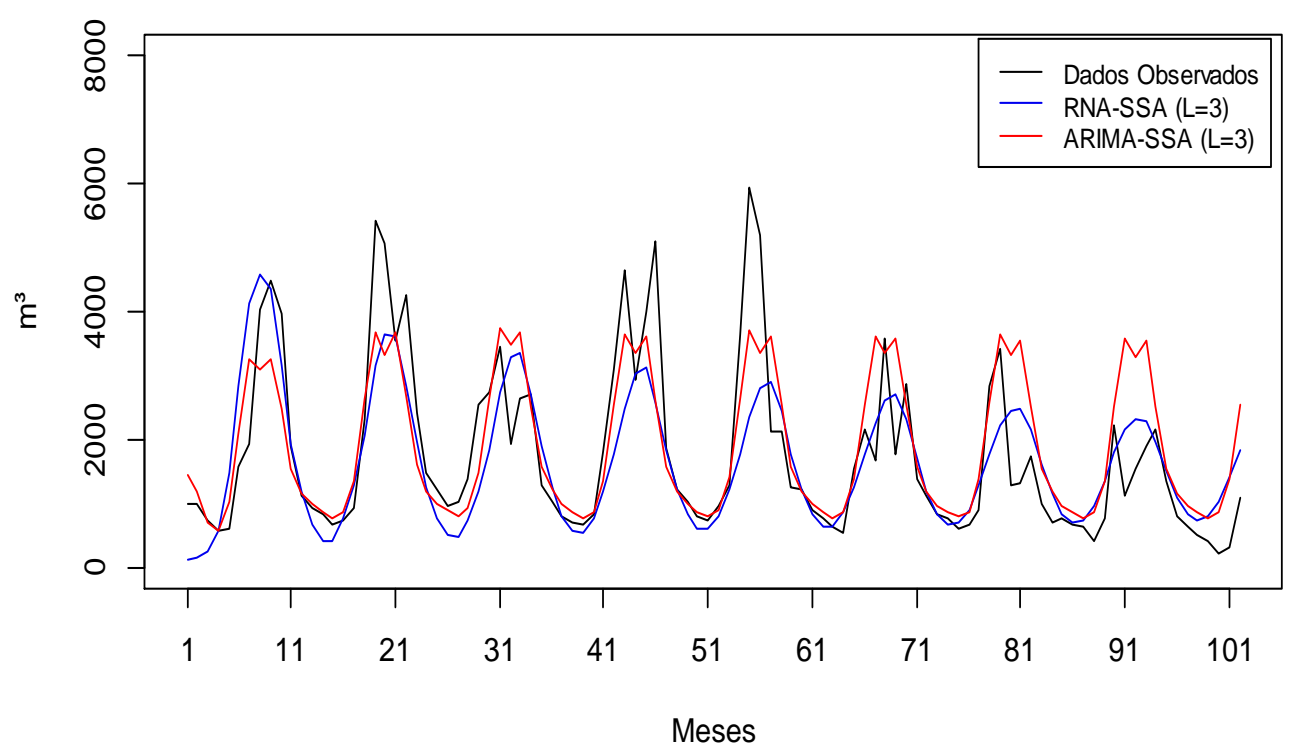

Figura 27 - Comparação entre os modelos de RNA e ARIMA com melhor desempenho para Sobradinho 


\section{5 \\ Conclusão e sugestões de trabalhos futuros}

Nas últimas décadas, pesquisas têm sido feitas no sentido de desenvolver métodos mais precisos de previsão de vazões hidrológicas. Com isso, a aplicação de modelos de inteligência artificial tem crescido, com destaque para o uso de modelos híbridos. Entretanto, na literatura não há consenso sobre a superioridade dos modelos híbridos frente as suas versões puras.

Com isso, esta dissertação desenvolveu modelos híbridos e puros combinando técnicas de previsão (ARIMA e RNA) com técnicas de préprocessamento de dados (SSA e STL) com o objetivo de comparar a performance dos modelos puros e híbridos e analisar a adequabilidade ambos para séries estacionárias e não estacionárias de vazões.

Para alcançar tais objetivos, a metodologia proposta foi aplicada a duas séries de vazões brasileiras: Sobradinho e Belo monte, sendo a primeira não estacionaria e a segunda estacionária, utilizando como horizonte de previsão de 102 passos à frente. Os modelos híbridos foram construídos levando em consideração a questão do uso incorreto de técnicas de pré-processamento na literatura apresentado por Zhang et al. (2015) e Du, Zhao e Lei (2017). A comparação dos resultados foi realizada através Raiz Quadrada do Erro Quadrático Médio (RMSE), Erro Médio Absoluto Percentual (MAPE), Coeficiente de eficiência de Nash-Sutcliffe (NSE) e Coeficiente de Eficiência de Kling-Gupta (KGE).

Os resultados obtidos indicam que para a série de Belo Monte (série estacionária), os modelos puros são melhores para o horizonte de previsão testado. Assim como o trabalho de Santos e Silva (2014), a dissertação aqui apresentada conclui que para Sobradinho (série não estacionária), em geral, os modelos híbridos são melhores. Com isso, este trabalho aponta que a indícios que estacionariedade é pode ser relevante para a definição de desempenho de um modelo híbrido e puro em uma série de vazão. Portanto, é necessário mais estudo para verificar tal relação. 
Além disso, neste trabalho o melhor modelo híbrido de previsão, construído com a técnica de pré-processamento SSA para a série de Sobradinho têm janela diferente de um múltiplo da sazonalidade, isto reforça a importância de se testar mais de uma janela para a decomposição SSA.

Como contribuições deste trabalho destacam-se o estudo comparativo de desempenho de modelos híbridos e puros, levando em consideração a questão da estacionariedade, análise ainda não realizada para séries de vazões brasileiras, e o destaque da estacionariedade da série como um possível fator relevante para a definição de desempenho de um modelo híbrido e puro em uma série de vazão.

Para trabalhos futuros recomenda-se a aplicação de outros modelos de previsão, como Extreme Learning Machines, que obteve um bom desempenho de previsão para série de vazões de Sobradinho, conforme o trabalho de Siqueira et al. (2018) e o uso de outras técnicas de pré-processamento de dados. Por fim, sugerese o desenvolvimento de modelos de previsão que incluam efeitos de longo prazo (El Niño, La Niña, Manchas Solares), além da possível inclusão de variáveis exógenas, informações climáticas (temperatura e precipitação, por exemplo) e vazões observadas em estações existentes na bacia. 


\section{6}

Referências bibliográficas

AKAIKE, H. A New Look at the Statistical Model Identification. I.E.E.E. Transactions on Automatic Control, p. 716-723, 1974.

ARMED, J. A.; SARMA, A. K. Artificial neural network model for synthetic streamflow generation. Water Resour Manage, 21, p. 10151029, 2007.

BOX, G.E.P.; COX, D. An analysis of transformations. J. Roy. Stat. Soc., 26 (2), p. 211-252, 1964.

BOX, G.E.P.; JENKINS, G.M. Time Séries Analysis, forecasting and control. San Francisco. Holden Day, 1970.

BOX, G. E. P.; JENKINS, G. M.; REINSEL, G. C. Time Series analysis: forecasting and control. s.l.:Willey., 2008.

BRITO, B. O.; SALGADO, R. M.; BEIJO, A. L. Intelligent Modeling for Streamflow Forecasting. IEEE Latin America Transactions, v. 14, n. 8, p. 3669-3677, 2016.

BROOMHEAD, D. S.; KING, G. P. Extracting qualitative dynamics from experimental data. Physica D, 20, p. 217-236, 1986.

CHENG, C. T. et al. Heuristic methods for reservoir monthly inflow forecasting: A case study of xinfengjiang reservoir in pearl river, China. Water (Switzerland), v. 7, n. 8, p. 4477-4495, 2015.

CHEN, X.; LI, F.; FENG, P. A new hybrid model for nonlinear and nonstationary runoff prediction at annual and monthly time scales. Journal of Hydro-environment Research, 20, p. 77-92, 2018.

CLEVELAND, R. B. et al. STL: A seasonal-trend decomposition procedure based on loess. Journal of Official Statistics, 1990.

CROMWELL, J. B.; LABYS, W. C.; TERRAZA, M. Univariate Tests for Time Series Models. Sage, Thousand Oaks, CA, 1994. 
CYRINO OLIVEIRA, F. L.; COSTA FERREIRA, P. G.; CASTRO SOUZA, R. A parsimonious bootstrap method to model natural inflow energy series. Mathematical Problems in Engineering, 2014.

DAWSON, C. W.; WILBY, R. L. Hydrological modelling using artificial neural networks. Progress in Physical Geography, v. 25, n. 1, p. 80-108, 2001.

DU, K.; ZHAO, Y.; LEl, J. The incorrect usage of singular spectral analysis and discrete wavelet transform in hybrid models to predict hydrological time series. Journal of Hydrology, v. 552, p. 44-51, 2017.

FAHIMI, F.; YASEEN, Z. M.; EL-SHAFIE, A. Application of soft computing based hybrid models in hydrological variables modeling: a comprehensive review. Theoretical and Applied Climatology, v. 128, n. 34, p. 875-903, 2017.

FAN, F.M. et al. Ensemble streamflow forecasting experiments in a tropical basin: The São Francisco river case study. Journal of Hydrology, 519, p. 2906-2919, 2014.

FENGA, L. Bootstrap Order Determination for ARMA Models: A Comparison between Different Model Selection Criteria. Journal of Probability and Statistics, 2017.

GOLYANDINA, N.; NEKRUTKIN, V.; ZHIGLJAVSKY, A. Analysis of Time Series Structure: SSA and Related Techniques. Chapman \& Hall/CRC, New York, 2001.

GOLYANDINA, N; KOROBEYNIKOV, A. Basic Singular Spectrum Analysis and Forecasting with R. Computational Statistics and Data Analysis, Vol. 71, 934-954, 2014.

GOLYANDINA, N.; ZHIGLJAVSKY, A. Singular Spectrum Analysis for time series. Springer Briefs in Statistics. Springer, 2013.

GUILHON, L.G.F.; ROCHA, V.F.; MOREIRA, J.C. Comparação de métodos de previsão de vazões naturais afluentes a aproveitamentos hidroelétricos. Rev. Bras. Recur. Hídr., 12 (3), p. 13-20, 2007.

GUPTA, H. V. et al. Decomposition of the mean squared error and NSE performance criteria: Implications for improving hydrological modelling. Journal of Hydrology, v. 377, n. 1-2, p. 80-91, 2009. 
HAMED, K. H. Trend detection in hydrologic data: The Mann-Kendall trend test under the scaling hypothesis. Journal of Hydrology, 349, $p$. 350- 363, 2008.

HASSANI H.; GHODSI, M. Singular Spectrum Analysis Using R. Springer, 2013.

HIRSCH, R.M.; SLACK, J.R.; SMITH, R.A. Techniques of trend analysis for monthly water quality data. Water Resources Research, 18 (1), pp. 107-121, 1982.

HIPEL, K. W.; MCLEOD, A. I. Time Series Modelling of Water Resources and Environmental Systems. p. 1012, 1994.

HOPFIELD, J. J. Artificial neural networks. IEEE Trans. Circuits Dev. Magaz., 4(5), p. 3-10, 1988.

HURVICH, C. M.; TSAI, C. L. Bias of the Corrected AIC Criterion for Underfitted Regression. Biometrika, 78(3), p. 499-509, 1991.

HYNDMAN RJ. Forecast: Forecasting functions for time series and linear models. $R$ package version 8.2, 2017 <URL: http://pkg.robjhyndman.com/forecast>.

JAIN, A.; KUMAR, A. M. Hybrid neural network models for hydrologic time series forecasting. Applied Soft Computing Journal, v. 7, n. 2, p. 585592, 2007.

KARTHIKEYAN, L.; NAGESH KUMAR, D. Predictability of nonstationary time series using wavelet and EMD based ARMA models. Journal of Hydrology, v. 502, p. 103-119, 2013.

KENDALL, M. G. Rank Correlation Methods. Griffin, London, 1975.

KUNDZEWICZ, Z. W.; ROBSON, A. J. Change detection in hydrological records-a review of the methodology. Hydrological Sciences Journal, 49, p. 7-19, 2004.

KWIATKOWSKI, D et al. Testing the Null Hypothesis of Stationarity against the Alternative of a Unit Root. Journal of Econometrics 54, p. 159-178, 1992.

LATIFOĞLU, L.; KIŞI, Ö.; LATIFOĞLU, F. Importance of hybrid models for forecasting of hydrological variable. Neural Computing and Applications, v. 26, n. 7, p. 1669-1680, 2015. 
LJUNG, G. M; BOX, G. E. P. On a measure of lack of fit in time series models. Biometrika 65, p. 297-303, 1978

MAIER, H. R. et al. Methods used for the development of neural networks for the prediction of water resource variables in river systems: Current status and future directions. Environmental Modelling and Software, v. 25, n. 8, p. 891-909, 2010.

MAIER, H. R.; DANDY, G. C. Neural networks for the prediction and forecasting of water resources variables: A review of modelling issues and applications. Environmental Modelling and Software, v. 15, n. 1, p. $101-$ 124, 2000.

MANN, H. B. Nonparametric tests against trend. Econometrica 13, 245259, 1945.

MARCATO, A. L. M. Representação hibrida de Sistemas Equivalentes e Individualizados para o Planejamento da Operação de Médio Prazo de Sistemas de Potência de Grande Porte. Tese de Doutorado em Engenharia Elétrica. Rio de janeiro, 2002. Pontifícia Universidade Católica do Rio de Janeiro.

MORIASI, D. N. et al. Model Evaluation Guidelines for Systematic Quantification of Accuracy in Watershed Simulations. Transactions of the ASABE, v. 50, n. 3, p. 885-900, 2007.

NAPOLITANO, G.; SERINALDI, F.; SEE, L. Impact of EMD decomposition and random initialisation of weights in ANN hindcasting of daily stream flow series: An empirical examination. Journal of Hydrology, v. 406, n. 3-4, p. 199-214, 2011.

NASH, J. E.; SUTCLIFFE, J.V. River flow forecasting through conceptual models part I-A discussion of principles. Journal of Hydrology, 10 (3), p. 282-290, 1970.

NOURANI, V. et al. Applications of hybrid wavelet-Artificial Intelligence models in hydrology: A review. Journal of Hydrology, v. 514, p. 358-377, 2014.

ONS. Operador Nacional do Sistema. ONS, 2018. Disponível em: $<$ http://www.ons.org.br/operacao/vazoes_naturais.aspx >, Acesso em: 10 janeiro de 2018. 
PEICAI, Y. The Prediction of Non-stationary Climate Series Based on Empirical Mode Decomposition. Advances in Atmospheric Sciences, v. 27, n. 4, p. 845-854, 2010.

R CORE TEAM. R: A language and environment for statistical computing. R Foundation for Statistical Computing, Vienna, Austria, 2017. URL https://www.R-project.org/.

ROUGÉ, X; GE, G.; CAI, C. Detecting gradual and abrupt changes in hydrological records. Advances in Water Resources, 53, pp. 33-44, 2013. SANTOS, C. A. G.; SILVA, G. B. L. DA. Daily streamflow forecasting using a wavelet transform and artificial neural network hybrid models. Hydrological Sciences Journal, v. 59, n. 2, p. 312-324, 2014.

SCHWARZ, G. Estimating the Dimension of a Model. The Annals of Statistics, 6(2), p. 461-464, 1978.

SERINALDI, F.; KILSBY, C. G.; LOMBARDO, F. Untenable nonstationarity: An assessment of the fitness for purpose of trend tests in hydrology. Advances in Water Resources, 111, p. 132-155, 2018. SIQUEIRA, $\mathrm{H}$ et al. Performance analysis of unorganized machines in streamflow forecasting of Brazilian plants. Applied Soft Computing Applied, 68(2018), p. 494-506, 2018.

SOUZA, R. C.; CAMARGO, M. E. Análise e Previsão de Séries Temporais: os modelos ARIMA. Ijuí: SEDIGRAF, 2004.

SPAETH, F. Modelo para previsão de vazão fluvial baseado em wavelets e redes neurais. Dissertação de Mestrado. Programa de Pós-Graduação em Ciências da Computação, Universidade Federal de Santa Catarina, Florianópolis, 2008.

STOFFER, D. astsa: Applied Statistical Time Series Analysis. R package version 1.8, 2017. https://CRAN.R-project.org/package=astsa SUGIURA, N. Further analysis of the data by Akaike's Information Criterion and the Finite Corrections. Communications in Statistics Theory and Methods, 7(1), p. 13-26, 1978.

TEIXEIRA, L.L et al. Previsões de vazões mensais via combinação híbrida Arima-neural com encolhimento e decomposição Wavelet. SBPO, 2015. 
THOMAS, H.A.; FIERING, M.B. Mathematical synthesis of stream-flow sequences for the analysis of river basins by simulation. In: Design of Water Resource Systems, Harvard Univ. Press, Cambridge, Massachuconjuntots, p. 459-493, 1962.

WANG et al. Forecasting daily streamflow using hybrid ANN models. Journal of Hydrology, 324, p. 383-399, 2006.

WU, C. L.; CHAU, K. W.; FAN, C. Prediction of rainfall time series using modular artificial neural networks coupled with data-preprocessing techniques. Journal of Hydrology, v. 389, n. 1-2, p. 146-167, 2010.

WU, C. L.; CHAU, K. W.; LI, Y. S. Predicting monthly streamflow using data-driven models coupled with data-preprocessing techniques. Water Resources Research, v. 45, n. 8, p. 1-54, 2009.

YASEEN, Z. M. et al. Artificial intelligence based models for streamflow forecasting: 2000-2015. Journal of Hydrology, v. 530, p. 829-844, 2015.

YANG, T. et al. Developing reservoir monthly inflow forecasts using artificial intelligence and climate phenomenon information. Water Resour. Res., 53, 2017.

YUE, S.; PILON, P.; CAVADIAS, G. Power of the Mann-Kendall and Spearman's rho for detrending monotonic trends in hydrological series. Journal of Hydrology, 259, pp. 254-271, 2002.

ZHANG, Q. et al. Singular Spectrum Analysis and ARIMA Hybrid Model for Annual Runoff Forecasting. Water Resources Management, v. 25, n. 11, p. 2683-2703, 2011.

ZHANG, X. et al. Are hybrid models integrated with data preprocessing techniques suitable for monthly streamflow forecasting? Some experiment evidences. Journal of Hydrology, v. 530, p. 137-152, 2015.

ZHANG, $X$. et al. Trends in Canadian streamflow. Water Resources Research, v. 37, n. 4, p. 987-998, 2001. 


\section{Anexo A}

Tabela A1. Resultado dos testes de estacionariedade para as vazões brasileiras

\begin{tabular}{|c|c|c|c|c|}
\hline Vazão & $\begin{array}{l}\text { Teste Mann- } \\
\text { Kendall }\end{array}$ & $\begin{array}{l}\text { Resultado (p- } \\
\text { valor = 0.05) }\end{array}$ & Bacia & $\begin{array}{c}\text { Tipo de } \\
\text { vazão }\end{array}$ \\
\hline CAMARGOS.(1) & 0.00 & Com tendência & Grande & Natural \\
\hline ITUTINGA.(2) & 0.00 & Com tendência & Grande & Natural \\
\hline FURNAS.(6) & 0.07 & Sem tendência & Grande & Natural \\
\hline MASCARENHAS.DE.MORAES.(7) & 0.02 & Com tendência & Grande & Natural \\
\hline ESTREITO.(8) & 0.03 & Com tendência & Grande & Natural \\
\hline JAGUARA.(9) & 0.03 & Com tendência & Grande & Natural \\
\hline IGARAPAVA.(10) & 0.03 & Com tendência & Grande & Natural \\
\hline VOLTA.GRANDE.(11) & 0.04 & Com tendência & Grande & Natural \\
\hline PORTO.COLÔMBIA.(12) & 0.07 & Sem tendência & Grande & Natural \\
\hline CACONDE.(14) & 0.84 & Sem tendência & Grande & Natural \\
\hline EUCLIDES.DA.CUNHA.(15) & 0.43 & Sem tendência & Grande & Natural \\
\hline A.S.OLIVEIRA.(16) & 0.41 & Sem tendência & Grande & Natural \\
\hline MARIMBONDO.(17) & 0.26 & Sem tendência & Grande & Natural \\
\hline ÁGUA.VERMELHA.(18) & 0.26 & Sem tendência & Grande & Natural \\
\hline BATALHA.(22) & 0.09 & Sem tendência & Paranaíba & Natural \\
\hline CORUMBÁ.III.(23) & 0.57 & Sem tendência & Paranaíba & Natural \\
\hline EMBORCAÇÃO.(24) & 0.03 & Com tendência & Paranaíba & Natural \\
\hline NOVA.PONTE.(25) & 0.00 & Com tendência & Paranaíba & Natural \\
\hline CAPIM.BRANCO.II.(28) & 0.09 & Sem tendência & Paranaíba & Natural \\
\hline ITUMBIARA.(31) & 0.02 & Com tendência & Paranaíba & Natural \\
\hline CACHOEIRA.DOURADA.(32) & 0.06 & Sem tendência & Paranaíba & Natural \\
\hline SÃO.SIMÃO.(33) & 0.00 & Com tendência & Paranaíba & Natural \\
\hline ILHA.SOLTEIRA.(34) & 0.02 & Com tendência & Paraná & Natural \\
\hline BARRA.BONITA.ARTIFICIAL.(37) & 0.00 & Com tendência & Tiête & Artificial \\
\hline A.S..LIMA.ARTIFICIAL.(38) & 0.00 & Com tendência & Tiête & Artificial \\
\hline IBITINGA.ARTIFICIAL.(39) & 0.00 & Com tendência & Tiête & Artificial \\
\hline PROMISSÃO.ARTIFICIAL.(40) & 0.00 & Com tendência & Tiête & Artificial \\
\hline NOVA.AVANHANDAVA.ARTIFICIAL.(42) & 0.00 & Com tendência & Tiête & Artificial \\
\hline TRÊS.IRMÃOS.ARTIFICIAL.(43) & 0.00 & Com tendência & Tiête & Artificial \\
\hline ILHA.SOLTEIRA.EQUIVALENTE.ARTIFICIAL.(44) & 0.00 & Com tendência & Paraná & Artificial \\
\hline JUPIÁ.ARTIFICIAL.(45) & 0.00 & Com tendência & Paraná & Artificial \\
\hline PORTO.PRIMAVERA.ARTIFICIAL.(46) & 0.00 & Com tendência & Paraná & Artificial \\
\hline A.A..LAYDNER.(47) & 0.00 & Com tendência & Paranapanema & Natural \\
\hline PIRAJU.(48) & 0.00 & Com tendência & Paranapanema & Natural \\
\hline CHAVANTES.(49) & 0.00 & Com tendência & Paranapanema & Natural \\
\hline LUCAS.NOGUEIRA.GARCEZ.(50) & 0.00 & Com tendência & Paranapanema & Natural \\
\hline CANOAS.II.(51) & 0.00 & Com tendência & Paranapanema & Natural \\
\hline CANOAS.I.(52) & 0.00 & Com tendência & Paranapanema & Natural \\
\hline MAUÁ.(57) & 0.00 & Com tendência & Paranapanema & Natural \\
\hline CAPIVARA.(61) & 0.00 & Com tendência & Paranapanema & Natural \\
\hline TAQUARUÇU.(62) & 0.00 & Com tendência & Paranapanema & Natural \\
\hline ROSANA.(63) & 0.00 & Com tendência & Paranapanema & Natural \\
\hline ITAIPU.ARTIFICIAL.(66) & 0.00 & Com tendência & Paraná & Artificial \\
\hline
\end{tabular}




\begin{tabular}{|c|c|c|c|c|}
\hline DESVIO.JORDÃO.ARTIFICIAL.(70) & 0.00 & Com tendência & Iguaçu & Artificial \\
\hline SANTA.CLARA.PR.(71) & 0.00 & Com tendência & Iguaçu & Natural \\
\hline FUNDÃO.(72) & 0.00 & Com tendência & Iguaçu & Natural \\
\hline DESVIO.JORDAO.(73) & 0.00 & Com tendência & Iguaçu & Natural \\
\hline FOZ.DO.AREIA.(74) & 0.00 & Com tendência & Iguaçu & Natural \\
\hline [SEGREDO.+.DESVIO].ARTIFICIAL.(75) & 0.00 & Com tendência & Iguaçu & Artificial \\
\hline SEGREDO.(76) & 0.00 & Com tendência & Iguaçu & Natural \\
\hline SALTO.SANTIAGO.(77) & 0.00 & Com tendência & Iguaçu & Natural \\
\hline SALTO.OSORIO.(78) & 0.00 & Com tendência & Iguaçu & Natural \\
\hline BAIXO.IGUAÇU.(81) & 0.00 & Com tendência & Iguaçu & Natural \\
\hline SÃO.ROQUE.(88) & 0.00 & Com tendência & Uruguai & Natural \\
\hline GARIBALDI.(89) & 0.00 & Com tendência & Uruguai & Natural \\
\hline ITÁ.(92) & 0.00 & Com tendência & Uruguai & Natural \\
\hline PASSO.FUNDO.(93) & 0.00 & Com tendência & Uruguai & Natural \\
\hline FOZ.DO.CHAPECÓ.(94) & 0.00 & Com tendência & Uruguai & Natural \\
\hline MONTE.CLARO.(97) & 0.00 & Com tendência & Jacuí & Natural \\
\hline CASTRO.ALVES.(98) & 0.00 & Com tendência & Jacuí & Natural \\
\hline ESPORA.(99) & 0.00 & Com tendência & Paranaíba & Natural \\
\hline SALTO.PILÃO.(101) & 0.00 & Com tendência & Atlântico Sudeste & Natural \\
\hline SÃO.JOSÉ.(102) & 0.00 & Com tendência & Uruguai & Natural \\
\hline PASSO.SÃO.JOÃO.(103) & 0.00 & Com tendência & Uruguai & Natural \\
\hline TRAIÇÃO.(104) & 0.01 & Com tendência & Tiête & Natural \\
\hline PEDREIRA.(109) & 0.15 & Sem tendência & Tiête & Natural \\
\hline ERNESTINA.(110) & 0.00 & Com tendência & Jacuí & Natural \\
\hline PASSO.REAL.(111) & 0.00 & Com tendência & Jacuí & Natural \\
\hline JACUÍ.(112) & 0.00 & Com tendência & Jacuí & Natural \\
\hline ITAUBA.(113) & 0.00 & Com tendência & Jacuí & Natural \\
\hline DONA.FRANCISCA.(114) & 0.00 & Com tendência & Jacuí & Natural \\
\hline GOVERNADOR.PARIGOT.DE.SOUZA.(115) & 0.00 & Com tendência & Capivari- Cachoeira & Natural \\
\hline PEDRAS.(116) & 0.16 & Sem tendência & Cubatão & Natural \\
\hline GUARAPIRANGA.(117) & 0.00 & Com tendência & Tiête & Natural \\
\hline BILLINGS.(118) & 0.15 & Sem tendência & Tiête & Natural \\
\hline BILLINGS+PEDRAS.(119) & 0.16 & Sem tendência & Tietê/Cubatão & Natural \\
\hline JAGUARI.(120) & 0.00 & Com tendência & Rio Paraíba do Sul & Natural \\
\hline PARAIBUNA.(121) & 0.25 & Sem tendência & Rio Paraíba do Sul & Natural \\
\hline SANTA.BRANCA.(122) & 0.33 & Sem tendência & Rio Paraíba do Sul & Natural \\
\hline FUNIL.(123) & 0.04 & Com tendência & Rio Paraíba do Sul & Natural \\
\hline STA.CECILIA.(125) & 0.03 & Com tendência & Rio Paraíba do Sul & Natural \\
\hline SIMPLÍCIO.ARTIFICIAL.(126) & 0.66 & Sem tendência & Rio Paraíba do Sul & Artificial \\
\hline ANTA.ARTIFICIAL.(127) & 0.55 & Sem tendência & Rio Paraíba do Sul & Artificial \\
\hline ANTA.(129) & 0.30 & Sem tendência & Rio Paraíba do Sul & Natural \\
\hline ILHA.DOS.POMBOS.(130) & 0.05 & Com tendência & Rio Paraíba do Sul & Natural \\
\hline NILO.PEÇANHA.(131) & 0.02 & Com tendência & Rio Paraíba do Sul & Artificial \\
\hline LAJES.ARTIFICIAL.(132) & 0.12 & Sem tendência & Rio Paraíba do Sul & Artificial \\
\hline SALTO.GRANDE.(134) & 0.00 & Com tendência & Doce & Natural \\
\hline BAGUARI.(141) & 0.00 & Com tendência & Doce & Natural \\
\hline MASCARENHAS.(144) & 0.00 & Com tendência & Doce & Natural \\
\hline RONDON.2.(145) & 0.88 & Sem tendência & Amazonas & Natural \\
\hline AIMORÉS.(148) & 0.00 & Com tendência & Doce & Natural \\
\hline CANDONGA.(149) & 0.00 & Com tendência & Doce & Natural \\
\hline RETIRO.BAIXO.(155) & 0.06 & Sem tendência & São Francisco & Natural \\
\hline TRÊS.MARIAS.(156) & 0.00 & Com tendência & São Francisco & Natural \\
\hline QUEIMADO.(158) & 0.00 & Com tendência & São Francisco & Natural \\
\hline ALTO.TIETÊ.(160) & 0.07 & Sem tendência & Tietê & Natural \\
\hline EDGARD.DE.SOUZA.COM.TRIBUTÁRIOS.(161) & 0.00 & Com tendência & Tietê & Natural \\
\hline EDGARD.DE.SOUZA.MENOS.TRIBUTÁRIOS.(164) & 0.00 & Com tendência & Tietê & Natural \\
\hline SOBRADINHO.INCREMENTAL.(168) & 0.00 & Com tendência & São Francisco & Natural \\
\hline SOBRADINHO.(169) & 0.00 & Com tendência & São Francisco & Natural \\
\hline ITAPARICA.(172) & 0.00 & Com tendência & São Francisco & Natural \\
\hline
\end{tabular}




\begin{tabular}{|c|c|c|c|c|}
\hline MOXOTÓ.(173) & 0.00 & Com tendência & São Francisco & Natural \\
\hline PAULO.AFONSO.(175) & 0.00 & Com tendência & São Francisco & Natural \\
\hline XINGÓ.(178) & 0.00 & Com tendência & São Francisco & Natural \\
\hline ANTÔNIO.DIAS.+.SÁ.CARVALHO.(183) & 0.00 & Com tendência & Doce & Natural \\
\hline ITAPEBI.(188) & 0.00 & Com tendência & Jequitinhonha & Natural \\
\hline BOA.ESPERANÇA.(190) & 0.03 & Com tendência & Parnaíba & Natural \\
\hline CANA.BRAVA.(191) & 0.03 & Com tendência & Tocantins & Natural \\
\hline ROSAL.(196) & 0.23 & Sem tendência & Itabapoana & Natural \\
\hline PICADA.(197) & 0.00 & Com tendência & Paraíba do Sul & Natural \\
\hline SOBRAGI.(198) & 0.00 & Com tendência & Paraíba do Sul & Natural \\
\hline ITAOCARA.(199) & 0.05 & Sem tendência & Paraíba do Sul & Natural \\
\hline TOCOS.(201) & 0.06 & Sem tendência & Paraíba do Sul & Natural \\
\hline LAJES/P.PASSOS/FONTES.NOVA.(202) & 0.73 & Sem tendência & Rio Paraíba do Sul & Natural \\
\hline SANTANA.(203) & 0.01 & Com tendência & Rio Paraíba do Sul & Natural \\
\hline CACHOEIRA.CALDEIRÃO.(204) & 0.07 & Sem tendência & Araguari & Natural \\
\hline CORUMBÁ.IV.(205) & 0.35 & Sem tendência & Paranaíba & Natural \\
\hline MIRANDA.(206) & 0.04 & Com tendência & Paranaíba & Natural \\
\hline CAPIM.BRANCO.I.(207) & 0.05 & Com tendência & Paranaíba & Natural \\
\hline CORUMBÁ.I.(209) & 0.54 & Sem tendência & Paranaíba & Natural \\
\hline FUNIL-GRANDE.(211) & 0.03 & Com tendência & Grande & Natural \\
\hline BARRA.GRANDE.(215) & 0.00 & Com tendência & Uruguai & Natural \\
\hline CAMPOS.NOVOS.(216) & 0.00 & Com tendência & Uruguai & Natural \\
\hline MACHADINHO.(217) & 0.00 & Com tendência & Uruguai & Natural \\
\hline MONJOLINHO.(220) & 0.00 & Com tendência & Uruguai & Natural \\
\hline SALTO.CAXIAS.(222) & 0.00 & Com tendência & Iguaçu & Natural \\
\hline SALTO.APIACÁS.(225) & 0.41 & Sem tendência & Amazonas & Natural \\
\hline SINOP.(227) & 0.10 & Sem tendência & Amazonas & Natural \\
\hline COLIDER.(228) & 0.10 & Sem tendência & Amazonas & Natural \\
\hline TELES.PIRES.(229) & 0.11 & Sem tendência & Amazonas & Natural \\
\hline SÃO.MANOEL.(230) & 0.11 & Sem tendência & Amazonas & Natural \\
\hline BARRA.BONITA.(237) & 0.00 & Com tendência & Tietê & Natural \\
\hline A.S..LIMA.(238) & 0.00 & Com tendência & Tietê & Natural \\
\hline IBITINGA.(239) & 0.00 & Com tendência & Tietê & Natural \\
\hline PROMISSÃO.(240) & 0.00 & Com tendência & Tietê & Natural \\
\hline SALTO.VERDINHO.(241) & 0.01 & Com tendência & Paranaíba & Natural \\
\hline NOVA.AVANHANDAVA.(242) & 0.00 & Com tendência & Tietê & Natural \\
\hline TRÊS.IRMÃOS.(243) & 0.00 & Com tendência & Rio Paraná & Natural \\
\hline JUPIÁ.(245) & 0.00 & Com tendência & Paraná & Natural \\
\hline PORTO.PRIMAVERA.(246) & 0.00 & Com tendência & Paraná & Natural \\
\hline CAÇU.(247) & 0.03 & Com tendência & Paranaíba & Natural \\
\hline BARRA.DOS.COQUEIROS.(248) & 0.04 & Com tendência & Paranaíba & Natural \\
\hline OURINHOS.(249) & 0.00 & Com tendência & Paranapanema & Natural \\
\hline SERRA.DO.FACÃO.(251) & 0.10 & Sem tendência & Paranaíba & Natural \\
\hline SÃO.SALVADOR.(253) & 0.04 & Com tendência & Tocantins & Natural \\
\hline PEDRA.DO.CAVALO.(254) & 0.00 & Com tendência & Atlântico Leste & Natural \\
\hline IRAPÉ.(255) & 0.00 & Com tendência & Jequitinhonha & Natural \\
\hline PEIXE.ANGICAL.(257) & 0.00 & Com tendência & Tocantins & Natural \\
\hline MURTA.(258) & 0.00 & Com tendência & Jequitinhonha & Natural \\
\hline ITIQUIRA.I.e.II.(259) & 0.00 & Com tendência & Paraguai & Natural \\
\hline FOZ.DO.RIO.CLARO.(261) & 0.04 & Com tendência & Paranaíba & Natural \\
\hline GUILMAN-AMORIM.(262) & 0.00 & Com tendência & Doce & Natural \\
\hline PORTO.ESTRELA.(263) & 0.00 & Com tendência & Doce & Natural \\
\hline ITAIPU.(266) & 0.00 & Com tendência & Paraná & Natural \\
\hline BALBINA.(269) & 0.00 & Com tendência & Amazonas & Natural \\
\hline SERRA.DA.MESA.(270) & 0.00 & Com tendência & Tocantins & Natural \\
\hline ESTREITO.TOCANTINS.(271) & 0.01 & Com tendência & Tocantins & Natural \\
\hline LAJEADO.(273) & 0.00 & Com tendência & Tocantins & Natural \\
\hline TUCURUI.(275) & 0.09 & Sem tendência & Tocantins & Natural \\
\hline CURUÁ-UNA.(277) & 0.05 & Com tendência & Amazonas & Natural \\
\hline
\end{tabular}




\begin{tabular}{|c|c|c|c|c|}
\hline MANSO.(278) & 0.68 & Sem tendência & Paraguai & Natural \\
\hline SAMUEL.(279) & 0.03 & Com tendência & Amazonas & Natural \\
\hline COARACY.NUNES.(280) & 0.07 & Sem tendência & Amazonas & Natural \\
\hline PONTE.DE.PEDRA.(281) & 0.00 & Com tendência & Paraguai & Natural \\
\hline SANTA.CLARA.MG.(283) & 0.00 & Com tendência & Mucuri & Natural \\
\hline 14.DE.JULHO.(284) & 0.00 & Com tendência & Jacuí & Natural \\
\hline JIRAU.(285) & 0.44 & Sem tendência & Amazonas & Natural \\
\hline QUEBRA.QUEIXO.(286) & 0.00 & Com tendência & Uruguai & Natural \\
\hline SANTO.ANTONIO.(287) & 0.44 & Sem tendência & Amazonas & Natural \\
\hline BELO.MONTE.(288) & 0.87 & Sem tendência & Amazonas & Natural \\
\hline SANTO.ANTÔNIO.DO.JARI.(290) & 0.93 & Sem tendência & Amazonas & Natural \\
\hline DARDANELOS.(291) & 0.46 & Sem tendência & Amazonas & Natural \\
\hline B.MONTE.PRINCIPAL.(292) & 0.84 & Sem tendência & Amazonas & Artificial \\
\hline SALTO.(294) & 0.01 & Com tendência & Paranaíba & Natural \\
\hline JAURU.(295) & 0.00 & Com tendência & Paraguai & Natural \\
\hline GUAPORÉ.(296) & 0.04 & Com tendência & Amazonas & Natural \\
\hline FERREIRA.GOMES.(297) & 0.07 & Sem tendência & Amazonas & Natural \\
\hline PIMENTAL.ARTIFICIAL.(302) & 0.70 & Sem tendência & Amazonas & Artificial \\
\hline
\end{tabular}




\section{Anexo B}

Tabela B1. Testes de estacionariedade para os componentes utilizados nos modelos ARIMA da série de Belo Monte e Sobradinho

\begin{tabular}{|c|c|c|c|c|c|}
\hline \multirow{3}{*}{ Modelo } & \multirow{2}{*}{ Componente } & p-valor & $\begin{array}{c}\text { Interpretação } \\
\text { do p-valor }\end{array}$ & peloalor & $\begin{array}{c}\text { Interpretação do p- } \\
\text { valor }\end{array}$ \\
\cline { 3 - 6 } & Tendência & 0.200 & Estacionária & 0.000 & Não Estacionária \\
\hline \multirow{3}{*}{ STL } & Sazonalidade & 0.962 & Estacionária & 0.937 & Estacionária \\
\cline { 2 - 6 } & Resíduos & 0.612 & Estacionária & 0.922 & Estacionária \\
\hline \multirow{2}{*}{ L=2 } & REC1 & 0.625 & Estacionária & 0.037 & Estacionária \\
\cline { 2 - 6 } & REC2 & 0.726 & Estacionária & 0.986 & Estacionária \\
\hline \multirow{3}{*}{ L=3 } & REC1 & 0.584 & Estacionária & 0.029 & Não Estacionária \\
\cline { 2 - 6 } & REC2 & 0.831 & Estacionária & 0.650 & Estacionária \\
\cline { 2 - 6 } & REC3 & 0.973 & Estacionária & 0.891 & Estacionária \\
\hline \multirow{2}{*}{ L=12 } & REC1 & 0.432 & Estacionária & 0.000 & Não Estacionária \\
\cline { 2 - 6 } & REC2 & 0.997 & Estacionária & 0.937 & Estacionária \\
\hline
\end{tabular}

